Revised Uranium-Plutonium Cycle PWR and BWR Models for the ORIGEN Computer Code
A. G. Croff
M. A.Bjerke
G. W. Morrison
L. M. Petrie 


\section{DISCLAIMER}

This report was prepared as an account of work sponsored by an agency of the United States Government. Neither the United States Government nor any agency Thereof, nor any of their employees, makes any warranty, express or implied, or assumes any legal liability or responsibility for the accuracy, completeness, or usefulness of any information, apparatus, product, or process disclosed, or represents that its use would not infringe privately owned rights. Reference herein to any specific commercial product, process, or service by trade name, trademark, manufacturer, or otherwise does not necessarily constitute or imply its endorsement, recommendation, or favoring by the United States Government or any agency thereof. The views and opinions of authors expressed herein do not necessarily state or reflect those of the United States Government or any agency thereof. 


\section{DISCLAIMER}

Portions of this document may be illegible in electronic image products. Images are produced from the best available original document. 


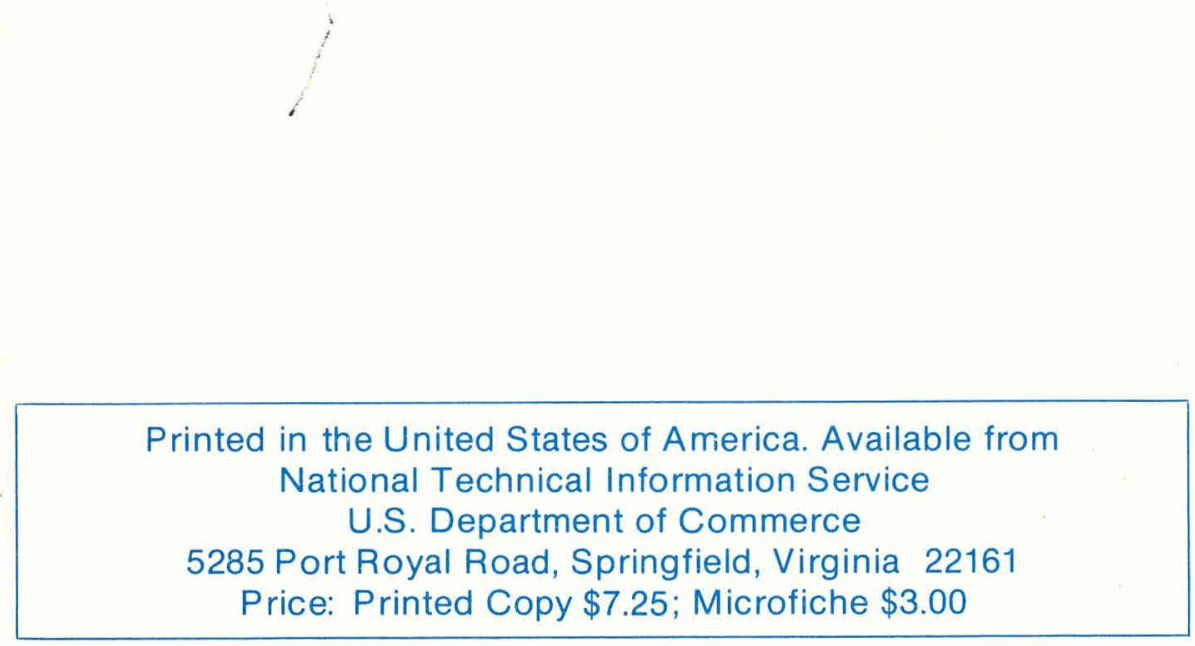

This report was prepared as an account of work sponsored by an agency of the United States Government. Neither the United States Government nor any agency thereof, nor any of their employees, contractors, subcontractors, or their employees, makes any warranty, express or implied, nor assumes any legal liability or responsibility for any third party's use or the results of such use of any information, apparatus, product or process disclosed in this report, nor represents that its use by such third party would not infringe privately owned rights. 
Contract No. W-7405-eng-26

CHEMICAL TECHNOLOGY DIVISION

\section{REVISED URANIUM-PLUTONIUM CYCLE PWR AND BWR MODELS FOR THE ORIGEN COMPUTER CODE}
A. G. Croff
M. A. Bjerke*
G. W. Morrison*
L. M. Petrie

${ }^{*}$ Computer Sciences Division, UCC-ND.

Date Published - September 1978

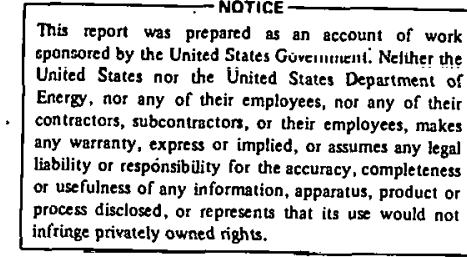

mon

OAK RIDGE NATIONAL LABURATORY

Oak Ridge, Tennessee 37830

operated by

UNION CARBIDE CORPORATION

for the

DEPARTMENT OF ENERGY 
THIS PAGE

\section{WAS INTENTIONALLY LEFT BLANK}


CONTENTS

Page

Figures .... ..................... . vi

Tables........................... vii

Glossary . . . . . . . . . . . . . . . . . . . . ix

Abstract . . . . . . . . . . . . . . . . . . . 1

1. Introduction and Summary . . . . . . . . . . . . . . 1

1.1 Introduction . . . . . . . . . . . . . . . 1

1.1.1 Background . . . . . . . . . . . . . . 1

1.1 .2 Scope .................. 3

1.2 Summary ..................... 5

1.3 References for Sect. 1 ................ 7

2. Description of the Generation of the Master, Multigroup

Cross Section Data Base . . . . . . . . . . . . . . 9

2.1 Scope and Source of Cross Section Data . . . . . . . 11

2.2 Resonance Nuclide Processing in NPTXS . . . . . . . 15

2.3 AMPX Master Interface Preparation by NEWXLACS . . . . . 16

2.4 References for Sect. 2 . . . . . . . . . . . 17

3. Multigroup Depletion Calculations . . . . . . . . . . 19

3.1 General Description of Cross Section Processing Codes . . 21

3.1.1 NITALL . . . . . . . . . . . . . . . 21

3.1.2 XSDRNPM .................. 23

3.1.3 CITATION ................. 24

3.2 Pin-Cell Calculations . . . . . . . . . . . . . 24

3.2.1 General approach . . . . . . . . . . . 24

3.2.2 Pin-cell description . . . . . . . . . . 25

3.2.3 Results of pin-cell calculations . . . . . . 28 
CONTENTS (continued)

Page

3.3 Assembly-Ce11 Calculations . . . . . . . . . . 30

3.3.1 General approach .. . . . . . . . . 30

3.3.2 Assembly-cell description . . . . . . . 30

3.3.3 Results of assembly-cell calculations . . . . 31

3.4 Fuel-Depletion Calculations . . . . . . . . . 33

3.4.1 General approach . . . . . . . . . . 33

3.4.2 CITATION depletion model description . . . . . 34

3.4.3 Results of CITATION depletion calculations . . . 41

3.5 Axial Neutron Energy Spectrum Calculations . . . . . 42

3.5.1 Gelleral apyivalh . . . . . . . . . . . . 42

3.5.2 Axial assembly model . . . . . . . . . . 42

3.5.3 Results of the axial spectrum calculations . . . 44

3.6 References for Sect. 3 . . . . . . . . . 48

4. Description of Reactor Models . . . . . . . . . . . 49

4.1 Discussion of ORIGEN Modifications . . . . . . . . 50

4.2 Input Compositions and Masses . . . . . . . . . . 53

4.2.1 Fuel-assembly structural material masses and compositions............... . 53

4.2.2 Nonactinide element composition of LWR oxide fuels ............... 55

4.2.3 Initial heavy-metal composition in LWR oxide fuels ................. 59

4.3 ORIGEN Depletion Calculations . . . . . . . . . . 59

4.3.1 Comparison of ORIGEN and CITATION depletion calculations . . . . . . . . . . . . . 61 
CONTENTS (continued)

Page

4.3.2 Comparison of ORIGEN and literature depletion calculations............. . 63 .

4.3.3 Summary description of the ORIGEN U-Pu cycle LWR models................ . 71

4.4 References for Sect. 4 . . . . . . . . . . . . 74

Appendix A: 84-Energy-Group Neutron Spectra Graphs and Listinge . . . . . . . . . . . . . . 81

Appendix B: One-Group, Spectrum-Averaged Cross Sections for U-Pu Cycle PWR and BWR Fuels ............ . 91

Appendix C: Plots and Listings of Selected Burnup-Dependent Cross Sections for ORIGEN . . . . . . . . . . . . . . 99 
Fig. 2.1. Procedure for processing raw cross section data into an AMPX master interface . . . . . . . . . . . . 10

Fig. 3.1. Procedure for processing AMPX master interface cross sections into ORIGEN cross sections . . . . . . . . . . 20

Fig. 3.2. CITATION fuel management model for the uranium-enriched PWR (PWR-U) after the first cycle.......... 36

Fig. 3.3. CITATION fuel management model for the uranium-enriched BWR (BWR-U) after the first cycle . . . . . . . . 37

Fig. 3.4. CITATION fuel management model for the plutonium-recycle PWR (PWR-Pu) after the first cycle . . . . . . . 39

Fig. 3.5. CITATION fuel management model for the plutonium-recycle BWR (BWR-Pu) after the first cycle . . . . . . . 40 
Tables

$\underline{\text { Page }}$

Table 2.1. Description of the processing of ENDF/B-formatted data into a master cross section library . . . . . . . . 12

Table 2.2. ORIGEN update nuclides included in fuel-depletion calculations ................. 13

Table 2.3. ORIGEN update nuclides not included in fuel depletion calculations ................. . 14

Tablc 3.1. Description of the processing of the master cross section 1ibrary into ORIGEN cross sections for LWRs . . . 22

Table 3.2. Pin-cell dimensions for the PWR . . . . . . . . . 26

Table 3.3. Pin-cell dimensions for the BWR . . . . . . . . 26

Table 3.4. CITATION cross section energy-group structure . . . . . 34

Table 3.5. Dimensions and material makeup of the PWR axial assembly model .....................43

Table 3.6. Dimensions and material makeup of the BWR axial assembly mode1 . . . . . . . . . . . . . . . . 45

Table 3.7. Summary of the results of the axial spectrum calculations ................ . 46

Table 4.1. Values of THERM, RES, and FAST to be used with LWR total fluxes ................ . 52

Table 4.2. Values of THERM, RES, and FAST to be used with LWR thermal fluxes . . . . . . . . . . . . . 52

Table 4.3. Assumed elemental compositions of LWR fuel-assembly structural materials .. . . . . . . . . . 54

Table 4.4. Assumed fuel-assembly structural material mass distribution . . . . . . . . . . . . . 56

Table 4.5. Physical characteristics of LWR fuel assemblies . . . . 57

Table 4.6. Assumed nonactinide composition of LWR oxide fuels . . . 58

Table 4.7. Assumed initial composition of one average metric ton of heavy metal in LWRs ... . . . . . . . . . 60

Table 4.8. Comparison of CITATION and ORIGEN depletion calculations at discharge for uranium-enriched LWRs . . . . . . . 62 
Table 4.9. Comparison of ORIGEN PWR-U fuel depletion calculations with literature values . . . . . . . . . . . 64

Table 4.10. Comparison of PWR-U discharged-fuel composition predicted by the old and new ORIGENs ......... 66

Table 4.11. Comparison of ORIGEN BWR-U fuel-depletion calculations with literature values ............ . 67

Table 4.12. Comparison of ORIGEN PWR-PuU fuel-depletion calculations with literature values . . . . . . . . . . 68

Table 4.13. Comparison of ORIGEN PWR-PuPu fuel-depletion calculations with literature values............. 69

Table 4.14. Results of ORIGEN BWR-PuU fuel depletion . . . . . . 72

Table 4.15. Comparison of ORIGEN BWR-PuPu fuel-depletion calculations with literature values... . . . . . . . . 73

Table 4.16. Summary of ORIGEN LWR model characteristics . . . • . 75 
BWR

BWR-PuPu

BWR-PuU

BWR-U

GWd

LWR

MWd

MTIHM

PWR

PWR-PuPu

PWR-PuU

PWR-U

Depletion calculation

Fuel element

Fuel assembly

Pin cell

Assembly cell
Boiling-water reactor

Self-generated mixed-oxide fuel in a BWR in which the plutonium is being recycled

Uranium-enriched fuel in a BWR in which the plutonium is being recycled

Uranium-enriched fuel in a wholly uranium-enriched BWR

Gi.gawatt-days $=10^{9}$ watt $=$ daye

Light water (moderated) reactor; i.e., BWRs and PWRs

Megawatt-days $=10^{6}$ watt-days

Metric tonnes $\left(=10^{6} \mathrm{~g}\right)$ of initial heavy metal

Pressurized water reactor

Self-generated mixed-oxide fuel in a PWR in which the plutonium is being recycled

Uranium-enriched fuel in a PWR in whlch the plutonium is being recycled

Uranium-enriched fuel in a wholly uranium-enriched PWR

Calculational irradiation of fresh reactor fuel resulting in the prediction of the discharged fuel composition

The smallest structurally discrete part of a fuel assembly which has nuclear fuel as its principal constituent; also called a fuel pin or a fuel rod

A grouping of fuel elements that is not taken apart during the charging and discharging of a reactor core

A cylindrical model of a fuel element used in a reactor physics calculation

A cylindrical model of a fuel assembly used in a reactor physics calculation 


\title{
REVISED URANIUM-PLUTONIUM CYCLE PWR AND BWR MODELS FOR THE ORIGEN COMPUTER CODE
}
A. G. $\operatorname{Croff}$,
M. A. Bjerke, *
G. W
Morrison, ${ }^{*}$ and L. M. Petrie

\section{ABSTRACT}

\begin{abstract}
Reactor physics calculations and literature searches have been conducted, leading to the creation of revised enriched-uranium and enriched-uranium/mixed-oxide-fueled PWR and BWR reactor models for the ORIGEN computer code. These ORIGEN reactor models are based on cross sections that have been taken directly from the reactor physics codes and eliminate the need to make adjustments in uncor:rected cross sections in order to obtain correct depletion results. Revised values of the ORIGEN flux parameters THERM, RES, and FAST were calculated along with new parameters related to the activation of fuel-assembly structural materials not located in the active fuel zone. Recommended fuel and structural material masses and compositions are presented. A summary of the new ORIGEN reactor models is given.
\end{abstract}

\section{INTRODUCTION AND SUMMARY}

\subsection{Introduction}

\section{1 .1 Background}

The ORIGEN $^{1}$ computer code is a versatile tool used for calculating the buildup and depletion of isotopes in nuclear materials. This computer code was written in the late 1960 s and early 1970s by the ORNL Chemical Technology Division. At that time, the required nuclear data libraries (half-lives, cross sections, fission product yields, etc.) and reactor models (PWR-U, PWR-Pu, LMFBR; HTGR, and MSBR) were also developed. The code was principally intended for use in generating spent fuel and waste

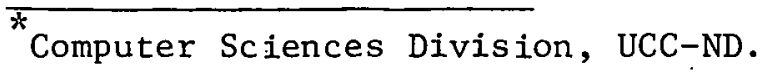


characteristics (composition, thermal power, etc.) that would form the basis for the study and design of fuel reprocessing plants, spent fuel shipping casks, waste treatment and disposal facilities, and waste shipping casks. Since fuel cycle operations were being examined generically, and thus were expected to accommodate a wide range of fuel characteristics, it was only necessary that the ORIGEN results be somewhat representative of this range. A satisfactory result was obtained by simply adjusting the resonance integrals of the major fissile and fertile species to obtain agreement with a spent fuel composition from an exogenous source.

Soon after the ORIGEN computer code. was documented, it was made available to users outside ORNL through the Radiation Shielding Information Center (at ORNL). The relative simplicity of ORIGEN coupled with its convenient and detailed output resulted in its being acquired by many organizations. Many of these organizations began using ORIGEN for applications that required greater precision in the calculated results than those for which it had originally been intended. 'linese applications were generally much more speciflc than the early oRNL generic fuel cycle studies, and many of these were environmental impact studies that required relatively precise calculations of minor isotopes such as ${ }^{3} \mathrm{H},{ }^{14} \mathrm{C},{ }^{232} \mathrm{U}$, and $242,244 \mathrm{Cm}$. The initial responses to these requirements were attempts to update specific aspects of ORIGEN and its data bases. ${ }^{2,3}$ However, inconsistencies and a large number of different data bases soon resulted from these efforts.

In an effort to remedy these problems, a concerted program was initiated in 1975 to update the ORIGEN computer code and its associated 
data bases and reactor models. This report is the first of several reports describing the various aspects of the ORIGEN update effort. Other reports to be issued in the future will document a revised version of the ORIGEN computer code, an updated decay data library, an updated photon library, additional updated libraries containing cross sections and fission product yields, and additional reactor models.

\section{1 .2 Scope}

This report is concerned with a description of a revised set of reactor models for PWRs and BWRs operating on uranium or uranium-plutonium fuels and the methods used to generate the information for these models. The PWR model was based on a Westinghouse design, ${ }^{4}$ and the BWR was based on a General Electric BWR/6 design. ${ }^{5}$ The specific reactor types considered in this report are as follows (see the Glossary for the definition of these and other terms):

1. PWR-U,

2. PWR-Pu (both PWR-PuU and PWR-PuPu fuel types),

3. BWR-U,

4. BWR-Pu (both BWR-PuU and BWR-PuPu fuel types).

The fundamental objective of this work was that ORIGEN would predict the correct spent fuel compositions without having to resort to the adjustment of cross sections, which had typified previous ORIGEN reactor models. This meant that ORIGEN had to be able to use cross sections which resulted from the processing of existing compilations such as $\mathrm{ENDF} / \mathrm{B}^{6}$

The generation of the information required for these reactor models began with the gathering and initial processing of existing raw cross 
section data Into an 84-neutron-energy-group library that could be used by a modular system of reactor physics $\operatorname{codes}^{7}$ (see Sect. 2). Two separate libraries were created: (1) a smaller library containing those nuclides whose presence in the reactor would have the greatest effects on the neutron spectrum and depletion characteristics and (2) a larger library containing many nuclides of interest in ORIGEN but having a minor effect. on the spectrum and depletion. Only the first of these libraries was considered in the subsequent multigroup fuel-depletion calculations.

Following these initial steps, burnup-dependent cross sections that accounted for spatial and energy self-shielding effects were generated for each of the six fuel types being considered (see Sect. 3). The libraries resulting from this procedure contained five neutron energy groups. The burnup-dependent, five-group libraries were then used in a diffusion-theory depletion code that predicted the composition of the spent tuel and supplied some of the cluss seliuils requircd by ORIGEN, The cross sections in the larger 84-group library mentioned previously were then collapsed to one-group cross sections using a "typical" neutron spectrum which was calculated while the burnup-dependent cross sections were being generated. Fission product yields were obtained by flux-weighting energy-dependent yields using the same neutron spectrum. Additional calculations were then performed which yielded new values of the ORIGEN flux parameters - THERM, RES, and FAST-- and parameters related to the activation of plenum springs and fuel-assembly end pieces. A modified version of the ORIGEN code was then developed and used to predict the composition of the spent fuel (see Sect. 4) using the cross sections generated by the more sophisticated reactor physics codes. 
The ORIGEN results were compared to both the results predicted by the multigroup fuel-depletion code and to spent fuel compositions obtained from the open literature. Finally, an investigation was undertaken to determine appropriate input parameters for the reactor models. The parameters investigated included the actinide composition of the fresh fuel, the impurity composition of the fresh fuel, and the structural material type and composition of a fuel. assembly.

\subsection{Summary}

This project involved the gathering and processing of a large amount of diverse data which led to the generation of revised ORIGEN reactor models for uranium- and uranium-plutonium-fueled PWRs and BWRs. The specific types of information developed for PWR-U, PWR-PuU, PWR-PuPu, BWR-U, BWR-PuU, and BWR-PuPu fuels are as follows:

1. 84-energy-group neutron spectra;

2. one-group, burnup-dependent cross sections for the major actinides;

3. one-group, "typical" cross sections for 233 nuclides (including the actinides);

4. new values for the ORIGEN flux parameters THERM, RES, and FAST;

5. parameters related to the activation of fuel-assembly structural materials outside the active fuel region;

6. recommended initial heavy-metal compositions of fresh fuel;

7. recommended initial metal compositions of fuel-assembly structural materials; and

8. recommended minor constituent concentrations for both the fuel material and the structural materials. 
Using this information and a modified version of the ORIGEN computer code, depletion calculations were made for each of the six fuel types. The results of these depletion calculations were compared to the results of diffusion-theory depletion calculations which were performed as a part of this program and to predicted discharge compositions obtained from literature sources.

In general, the results of the ORIGEN depletion calculations agreed very well with the literature values for all three of the PWR fuels. Adequate agreement was obtained for the BWR-U fuel and fair agreement for the BWR-PuPu fuel. Comparative literature values were not available for the BWR-PuU fuel. It should be noted that the moderator density in the BWR calculations was increased to a value $20 \%$ greater than the volume-averaged moderator density (i.e., a value nearer the power-averaged moderator density) to obtain the agreement indicated. The results of the PWR-U and BWR-U fuel depletions trom UKLGEN and the diffusion-theory code were found to be in excellent agreement. This agreement is expected since ORIGEN uses cross sections that had been generated by the diffustontheory code. Based on the ORIGEN vs literature comparisons which were made as a part of this project, it appears that the cross section information is adequate for performing depletion calculations for fuel enrichments within a few tenths of a percentage point of the enrichments used in generating the cross sections for the reactor models. However, the depletion calculations will become progressively less accurate as the fuel composition deviates from the reference conditions. 


\subsection{References for Sect. 1}

1. M. J. Bell, ORIGEN - The ORNL Isotope Generation and Depletion Code, ORNL-4628 (May 197.3).

2. C. W. Kee, A Revised Light Element Library for the ORIGEN Code, ORNL/TM-4896 (May 1975).

3. C. W. Kee, C. R. We1sbin, and R. E. Schenter, Processing and Testing of ENDF/B-IV fission Product and Transmutation Data, Trans. Am. Nucl. Soc. 19, 398-399 (1974).

4. Wesținghouse Nuclear Energy Systems, RESAR-3, Reference Safety Analysis Report, DOCKET STN 50-480 (1972).

5. General Electric Standard Safety Analysis Report, BWR/6, DOCKET STN 50-447 (1973).

6. ENDF/B-IV Library Tapes 401-411 and 414-419, available from the National Neutron Cross Section Center, Brookhaven National Laboratory (December 1974).

7. N. M. Greene, J. L. Lucius, L. M. Petrie, W. E. Ford III, J. E. Wh1te, and R. Q. Wright, AMPX: A Modular Code System for Generating Coupled Multigroup Neutron-Gamma Libraries from ENDF/B, ORNL/TM-3706 (March 1976). 
THIS PAGE

\section{WAS INTENTIONALLY LEFT BLANK}


2. DESCRIPTION OF THE GENERATION OF THE

MASTER, MULTIGROUP CROSS SECTION DATA BASE

This section describes the processing of raw cross section data into a multiple energy group (multigroup) cross section library that is suitable for use in reactor neutron energy spectrum and fuel-depletion calculations. This library will be applicable to a wide variety of uranium-plutonium (U-Pu) cycle LWRs.

A schematic information flow diagram for the processing of the raw cross section data is given in Fig. 2.1. In this diagram, the principal computer codes used in processing the cross sections are contained in rectangular figures. Descriptions of the cross section parameters which comprise the input to and output from each computer code are contained in the oval figures. The sources of the raw cross section data are discussed in Sect.2.1. The two principal computer codes required to process this raw data into the multigroup cross section library are NPTXS ${ }^{1}$ and NEWXLACS. ${ }^{1}$

There are two principal steps involved in processing the raw cross section data into a master library, as depicted in Fig. 2.1. The first of these generates point cross section data that are very closely spaced for those few isotopes $\left({ }^{235,238} \mathrm{U}\right.$ and $\left.{ }^{239-242} \mathrm{Pu}\right)$ whose resonance neutron absorptions are important in U-Pu cycle reactors using NPTXS. These data, along with raw data for the remaining isotopes, are neutron-energyspectrum-weighted within each of the neutron energy groups that are to be included in the master library using an input weighting function that is generally typical of thermal reactors. The result of this two-step processing sequence, which is described in detail in Sects. 2.2 and 2.3, 


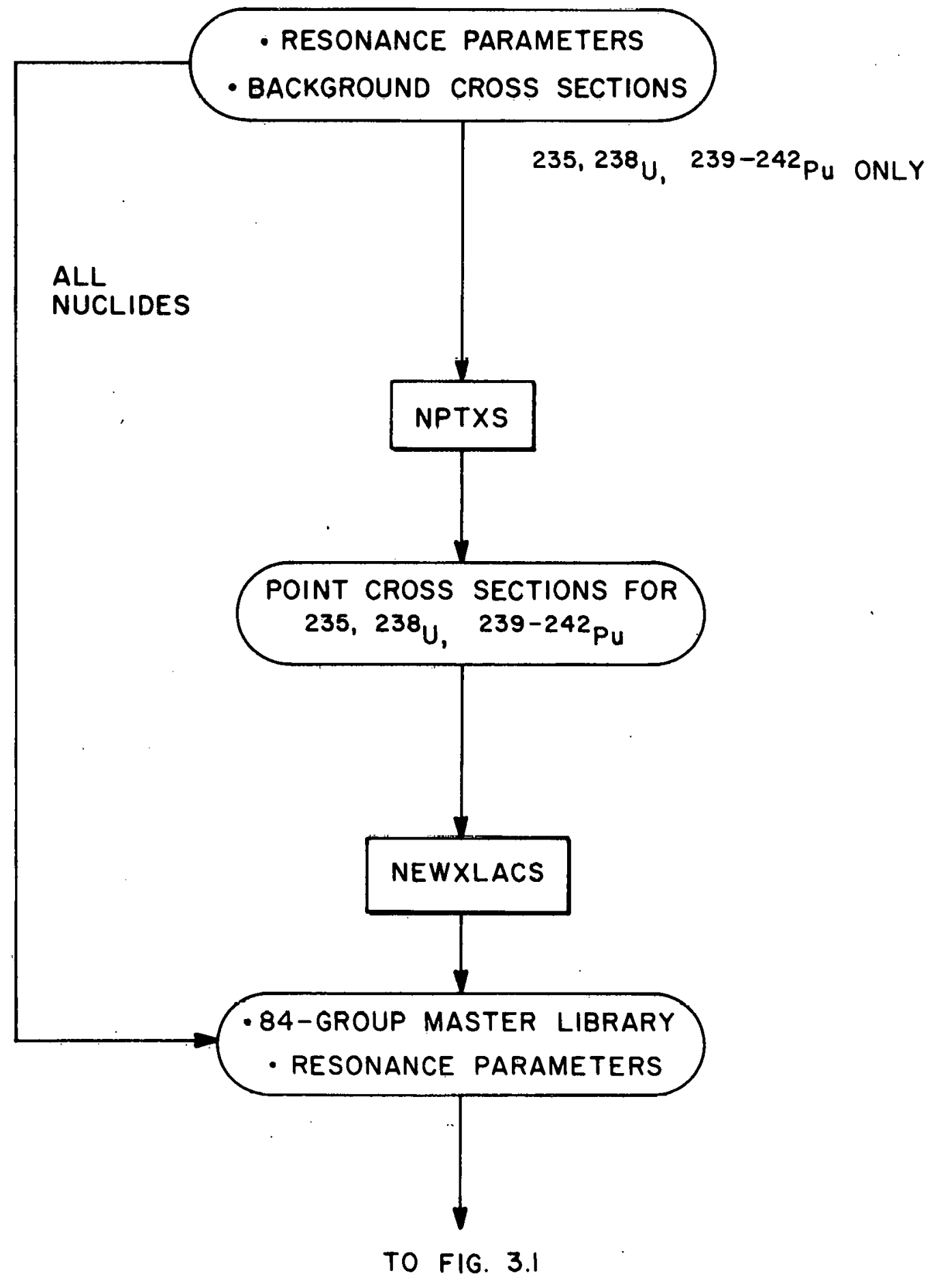

Fig. 2.1. Procedure for processing raw cross section data into an AMPX master interface. 
is the master cross section library. A summary description of the processing sequence is given in Table 2.1 .

\subsection{Scope and Source of Cross Section Data}

The cross section data base used in the multigroup reactor physics calculations described in Sect. 3 contains all cross sections that could be cast into a multigroup library (as of spring 1977) and that were machine-readable. These cross sections were obtained from three principal sources: ENDF/B-IV, ${ }^{2}$ LENDL (Livermore Evaluated Nuclear Data Library), ${ }^{3}$ and Benjamin. ${ }^{4}$ The cross section data obtained from these sources were divided into two groups: (1) the actinides, moderators, poisons, and principal structural materials and (2) the fission products, minor impurities, and minor structural materials. The first group of nuclides is neutronically important in the reactor, and all of these nuclides were represented explicitly in the depletion calculations. The cross sections of nuclides in the second group were obtained by collapsing the multigroup cross sections using a neutron spectrum selected after the depletion calculation had been performed. A list of the nuclides in the first and second groups and the sources of the data are given in Tables 2.2 and 2.3 .

Certain ${ }^{238} \mathrm{U}$ cross section parameters were adjusted according to a recipe supplied by Benjamin ${ }^{5}$ in order to obtain agreement with the experimental data. Changes in the neutron capture cross section were made between $0.00025 \mathrm{eV}$ and $0.7067 \mathrm{eV}$, in the neutron and radiation widths for the low-1ying s-wave resonances between $6.65 \mathrm{eV}$ and $165 \mathrm{eV}$, and in the unresolved resonance parameters. 
Table 2.1. Description of the processing of ENDF/B-formatted data inta a naster cross section library

\begin{tabular}{|c|c|c|c|c|}
\hline $\begin{array}{l}\text { Computer } \\
\text { code }\end{array}$ & Input & Function & Output & $\begin{array}{l}\text { Applicability } \\
\text { of result }\end{array}$ \\
\hline NPTXS & $\begin{array}{l}\text { Resonance parameters } \\
\text { and ba:kground cross } \\
\text { sections in ENDFiB } \\
\text { format }\end{array}$ & $\begin{array}{l}\text { Generate Dofpler-broadened } \\
\text { point cross sections for } \\
\text { resonance neclides } \\
\left({ }^{235,2: 38} \mathrm{U}, 339-242 \mathrm{Pu}\right)\end{array}$ & $\begin{array}{l}\text { Point cross sections, } \\
\text { background cross } \\
\text { sections, and reson- } \\
\text { ance parameters for } \\
\text { resonance nuclides }\end{array}$ & A11 U-Pu LWRs \\
\hline NEWXIACS & $\begin{array}{l}\text { Resonance parameters } \\
\text { and bazkground cross } \\
\text { sections in ENDF;B } \\
\text { format plus point } \\
\text { cross sections for } \\
\text { resonance nuclides } \\
\text { from NPTXS }\end{array}$ & $\begin{array}{l}\text { Gererace multigroup } \\
\text { crcss secticns from point } \\
\text { crcss secticns using } \\
\text { Maxwellian-l/E-fission- } \\
\text { specirum weighting } \\
\text { furction }\end{array}$ & $\begin{array}{l}84-\text { group master } \\
\text { library, including } \\
\text { resonance parameters }\end{array}$ & Al1 U-Pu LWRs \\
\hline
\end{tabular}


Table 2.2. ORIGEN update nuclides included in fuel-depletion calculations

\begin{tabular}{|c|c|c|c|c|c|c|c|c|c|}
\hline Nuclide & Ref. & Nuclide & $\operatorname{Ref}$ & Nuclide & Ref. & Nuclide & $\operatorname{Ref}$. & Nuclide & Ref. \\
\hline $\mathrm{H}-1$ & 2 & $B-10$ & 2 & B-11 & 2 & $\mathrm{C}-12$ & 2 & $\mathrm{~N}-14$ & 2 \\
\hline $0-16$ & 2 & $\mathrm{Na}-23$ & 2 & $\mathrm{Cr}-52$ & 2 & $M n-55$ & 2 & $\mathrm{Fe}-56$ & 2 \\
\hline $\mathrm{Ni}-58$ & 2 & $\mathrm{Zr}-92^{\mathrm{a}}$ & 2 & $\mathrm{Nb}-93$ & 2 & Mo-98 & 2 & $S n-119$ & 3 \\
\hline Th-232 & 2 & $\mathrm{~Pa}-233$ & 2 & $\mathrm{U}-233$ & 2 & $U-234$ & 2 & $\mathrm{U}-235$ & 2 \\
\hline $\mathrm{U}-236$ & 2 & $\mathrm{U}-237$ & 3 & $\mathrm{U}-238^{\mathrm{b}}$ & 2 & $\mathrm{U}-239$ & 3 & U-240 & 3 \\
\hline$N p-237$ & 2 & $\mathrm{~Np}-238$ & 4 & $\mathrm{Pu}-236$ & 4 & $\mathrm{Pu}-238$ & 2 & $\mathrm{Pu}-239$ & 2 \\
\hline $\mathrm{Pu}-240$ & 2 & $\mathrm{Pu}-241$ & 2 & $\mathrm{Pu}-242$ & 2 & $\mathrm{Pu}-243$ & 4 & $A m-241$ & 2 \\
\hline $\mathrm{Am}-242 \mathrm{M}$ & 4 & $\mathrm{Am}-242$ & 4 & $\mathrm{Am}-243$ & 4 & $\mathrm{Cm}-242$ & 4 & $\mathrm{Cm}-243$ & 4 \\
\hline $\mathrm{Cm}-244$ & 4 & $\mathrm{Cm}-245$ & 4 & $\mathrm{Cm}-246$ & 4 & $\mathrm{Cm}-247$ & 4 & $\mathrm{Cm}-248$ & 4 \\
\hline$B k-249$ & 4 & Cf -249 & 4 & Cf -250 & 4 & $\mathrm{Cf}-251$ & 4 & $C f-252$ & 4 \\
\hline $\mathrm{Cf}-253$ & 4 & $\mathrm{Cf}-254$ & 4 & $\mathrm{Es}-253$ & 4 & & & & \\
\hline
\end{tabular}

${ }^{a}$ Zircaloy-2.

${ }^{b}$ Some resonance parameters adjusted from ref. 2 values according to recipe given in ref. 5. 
Table 2.3. ORIGEN update nuclides not included in fuel depletion calculations ${ }^{a}$

\begin{tabular}{|c|c|c|c|c|c|c|c|}
\hline$G E-72$ & GE- 73 & GE- 74 & AS - 75 & GE- 76 & SE- 76 & $S E-77$ & $s E-78$ \\
\hline$R-79$ & $S E-80$ & $K R-80$ & $B R-81$ & $S E-82$ & $K R-82$ & $\mathrm{KR}-83^{-}$ & $K R-84$ \\
\hline$R-85$ & $R B-85$ & $K R-86$ & $R B-86$ & $S R-86$ & $\mathrm{RB}-87$ & $S R-87$ & $S R-88$ \\
\hline$R-89$ & $Y-89$ & $S R-90$ & $Y-90$ & $Z R-90$ & $Y-91$ & $Z R-91$ & $2 R-93$ \\
\hline$R-94$ & $N B-94$ & MO- 94 & $Z R-95$ & $N B-95$ & Mo- 95 & $Z R-96$ & MO- 96 \\
\hline $0-97$ & MO- 99 & TC- 99 & RU- 99 & MO- 100 & $\mathrm{RO}-100$ & $R O-101$ & $R U-102$ \\
\hline $0-103$ & $\mathrm{RH}-103$ & $\mathrm{RU}-104$ & PD- 104 & R D- 105 & $\mathrm{RH}-105$ & $P D-105$ & $\mathrm{RO}-106$ \\
\hline$D-106$ & $P D-107$ & $A G-107$ & PD- 108 & $C D-108$ & $A G-109$ & $P D-110$ & $C D-110$ \\
\hline$G-111$ & $C D-111$ & $C D-112$ & $C D-113$ & $\mathrm{IN}-113$ & $C D-114$ & $C D-115 M$ & $I N-115$ \\
\hline $5 N-115$ & $C D-116$ & $S N-116$ & $S N-117$ & $\mathrm{SN}-118$ & $5 N-119$ & $S N-120$ & $S B-121$ \\
\hline$N-122$ & $T E-122$ & $S N-123$ & $S B-123$ & $T E-123$ & $S N-124$ & $S B-124$ & $T E-124$ \\
\hline$S N-125$ & $S B-125$ & $T E-125$ & $S N-126$ & $S B-126$ & $T E-126$ & $T E-127 M$ & $I-127$ \\
\hline$E-128$ & $x E-128$ & $T E-129 M$ & I -129 & $\mathrm{XE}-129$ & $T E-130$ & I -130 & $X E-$ \\
\hline$I-131$ & $X E-131$ & $T E-132$ & $X E-132$ & $x E-133$ & $c s-133$ & $X E-134$ & Cs- \\
\hline$B A-134$ & $I-135$ & $X E-135$ & Cs- 135 & $B A-135$ & $X E-136$ & $c s-136$ & BA- \\
\hline$=s-137$ & $B A-137$ & $B A-138$ & $L A-139$ & $B A-140$ & $L A-140$ & $C E-140$ & $C E-$ \\
\hline $2 R-141$ & $C E-142$ & $P R-142$ & ND- 142 & $C E-143$ & $P R-143$ & ND- 143 & $C E-$ \\
\hline N D -144 & ND -145 & ND-146 & ND -147 & $P M-147$ & $S M-147$ & $N D-148$ & $\mathrm{PM}-$ \\
\hline$P M-148 M$ & $S M-148$ & $P B-149$ & $S H-149$ & ND- 150 & $S M-150$ & $P M-151$ & $S M-$ \\
\hline$E U-151$ & $S M-152$ & EO-152 & $S M-153$ & $5 M-154$ & $E D-154$ & $G D-154$ & $E U-155$ \\
\hline$G D-155$ & $\mathrm{EU}-156$ & $G D-156$ & $\mathrm{EU}-157$ & $G D-157$ & $G D-158$ & TB-159 & $G D-160$ \\
\hline$T B-160$ & $D Y-160$ & $D Y-161$ & $D Y-162$ & $D Y-163$ & $D Y-164$ & HO-165 & $E R-166$ \\
\hline
\end{tabular}

${ }^{\mathrm{a}} \mathrm{All}$ cross sections taken from ref. 2 . 
2.2 Resonance Nuclide Processing in NPTXS

The nuclides included in the first (neutronically important) group can be separated into two classes: resonance nuclides and nonresonance nuclides. Nuclides in the first class are those which contribute significantly to the resonance absorption in the system(s) of interest. For the purposes of this study (U-Pu cycle thermal reactors), the following nuclides fall in this class: ${ }^{235} \mathrm{U},{ }^{238} \mathrm{U}$, and ${ }^{239-242} \mathrm{Pu}$.

The AMPX ${ }^{1}$ module NPTXS is used to process the resonance parameters contained in the ENDF/B data ${ }^{2}$ for those nuclides listed above. In the resolved resonance range, each resonance is described by a few parameters (resonance energy, neutron widths, etc.) which are used as variables in a mathematical representation of the resonance shape. NPTXS uses these mathematical functions to reconstruct each of the resonances, giving the equivalent cross section at a number of energy points which span the resolved range. In the unresolved range, only average resonance quantities are given because the resonances are too closely spaced to be distinguished. The distribution of the average quantities can be integrated (flux-averaged) to yield average cross sections at energy points which span the unresolved range. The point cross sections for the resonance nuclides are used by $\operatorname{NEWXLACS}^{1}$ (see Sect. 2.3) to calculate the scattering matrix.

The background cross sections from file 3 of ENDF/B are added to those calculated in the resonance regions and output to a file which is similar to an ENDF/B file 3. Only the total, elastic, fission, and capture cross sections are put on this file, and the data are Dopplerbroadened to a specified temperature $\left(1000^{\circ} \mathrm{K}\right.$ in our case). The data in 
the unresolved resonance range are evaluated at an input value of $\sigma_{0}$ that is indicative of the system in which these cross sections will be used. ( $\sigma_{0}$ is the total cross section of the surrounding medium.)

\subsection{AMPX Master Interface Preparation by NEWXLACS}

The purpose of NEWXLACS ${ }^{1}$ is to create an AMPX master interface (i.e., a master cross section library) which contains all of the s-wave resonance parameters, the flux-averaged group cross sections, and the scattering matrix required in subsequent steps. NEWXLACS requires as input the ENDF/B-format tape for the desired nuclide and, if it is a resonance nuclide, the NPTXS-created file of point cross sections.

If the nuclide is not a resonance nuclide, NEWXLACS group-averages the point cross sections from file 3 of the ENDF/B-formatted data with an input weighting function. This weighting function was a Maxwellian thermal spectrum coupled to a $1 / E$ spectrum in the resonance range which was coupled to a fission spectrum in the fast region. These data are Doppler-broadened to a specified temperature. If it is a resonance nuclide, NEWXLACS puts both the resonance parameters and the group background cross sections on the interface so that the NITAWL module can be used to analyze systems with various resonance nuclide concentrations. These group background cross sections are evaluated for the total, elastic, fission, and capture reactions and taken from the file 3 background in ENDF/B and averaged over the weight function mentioned above.

All the other reactions in the ENDF/B file are group-averaged using the weight function and placed on the master interface. This includes the values for total, elastic, fission, and capture that are taken from 
the NPTXS-created file. The elastic scattering point data from this latter file are also used in conjunction with the secondary energy/angle distributions in the ENDF/B file to generate group-to-group transfer arrays (i.e., the scattering matrix) for the master interface.

\subsection{References for Sect. 2}

1. N. M. Greene, J. L, Lucius, L. M. Petrie, W. E. Ford III, J. E. White, and R. Q. Wright, AMPX: A Modular Code System for Generating Coupled Multigroup Neutron-Gamma Libraries from ENDF/B, ORNL/TM-3706 (March 1976).

2. ENDF/B-IV Library Tapes 401-411 and 414-419, available from the National Neutron Cross Section Center, Brookhaven National Laboratory (December 1974).

3. R. J. Howerton, D. E. MacGregor, S. T. Perkins, and E. F. Plechaty, The LLL Evaluated Nuclear Data Library (ENDL): Evaluation Techniques, Reaction Index, and Descriptions of Individual Evaluations, UCRL-50400, Vo1. 15, Part A (September 1975).

4. R. W. Benjamin, F. J. McCrosson, and P. L. Roggenkamp, Conversion of ${ }^{238} \mathrm{Pu}$ and ${ }^{252} \mathrm{Cf}$ Production Chain Cross Section Data to ENDF/B-IV Format, EPRI-NP-161 (December 1975).

5. R. W. Benjamin, Savannah River Laboratory, personal communication to A. G. Croff, Oak Ridge National Laboratory, January 1977. 
THIS PAGE

\section{WAS INTENTIONALLY \\ LEFT BLANK}




\section{MULTIGROUP DEPLETION CALCULATIONS}

The 84-energy-group AMPX master cross section library described in Sect. 2 of this report contains cross section information of a general nature for solving U-Pu cycle thermal reactor problems. This section describes the processing of this general, multigroup library into problem-dependent, burnup-dependent, multigroup libraries and then into problem-dependent, one-group libraries used in ORIGEN.

A schematic information flow diagram for the processing of the master cross section library into the problem-dependent, one-group libraries is given in Fig. 3.1. In this diagram, the principal computer codes used in processing the cross sections are contained in rectangular figures. Descriptions of the cross section parameters which comprise the input to and output from each computer code are contained in the curved figures. As is evident from Fig. 3.1, there are three principal cross section processing codes: NITAWL, ${ }^{1}$ XSDRNPM, ${ }^{1}$ and CITATION. ${ }^{2}$

A general description of these three computer codes is given in Sect. 3.1.

There are four principal steps involved in processing the master cross section library into ORIGEN libraries, as depicted in Fig. 3.1. The first of these is to perform "pin-cel1" neutron energy spectrum calculations at three (for a PWR) or four (for a BWR) different burnups using NITAWL and XSDRNPM which are used to account for self-shielding effects for the nuclides in Table 2.2. The second processing step is to perform "assembly-cell" spectrum calculations using these same computer codes to account for the fact that the fuel elements at the center of a fuel assembly see a significantly different neutron spectrum than those on the periphery of the assembly because of the varying characteristics 


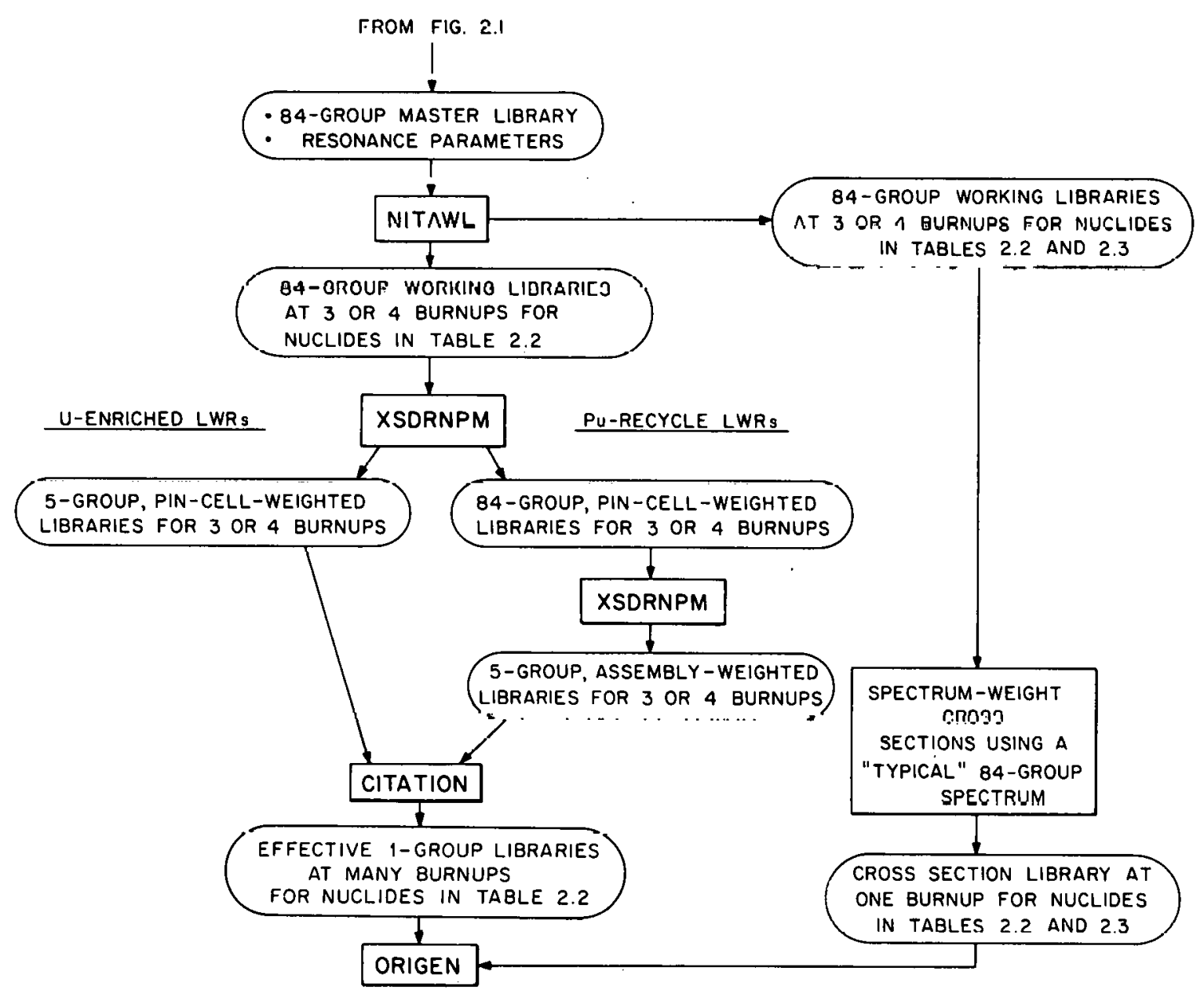

l'ig. J.1. lrocedure for processing AMl'X master interface crosa sections into ORIGEN cross sections. 
of the surrounding assemblies. This step is only performed for LWRs containing both plutonium- and uranium-enriched fuel. The third step is to perform fuel-depletion calculations with CITATION using few-group, self-shielded cross sections from XSDRNPM. The principal result of the CITATION calculation is one-group, burnup-dependent cross sections for a few of the most neutronically important actinides. The final step is to use a single neutron energy spectrum that is "typical" of each fuel type to collapse the multigroup cross sections for the nuclides in Tables 2.2 and 2.3 to one-group cross sections for ORIGEN. A summary description of this four-step processing sequence is given in Table 3.1 . A detailed description of each of the four steps is given in Sects. 3.2 to 3.4 .

A final, somewhat separate calculation that was performed involved using the XSDRNPM computer code to calculate the axial neutron flux shape and energy spectrum for uranium-enriched BWR and PWR fuel assemblies. These calculations, which are described in Sect. 3.5, result in a prediction of the activation of fuel-assembly end pieces and fuel-element plenum springs.

\subsection{General Description of Cross Section Processing Codes}

\section{1 .1 NITAWL}

The NITAWL ${ }^{1}$ computer code is used to account for resonance selfshielding effects in nuclides with resonance parameters. That is, given information about the fuel region of a pin cell, such as the Doppler temperature, moderator concentration, pin-cell dimensions, and resonance nuclide concentrations, NITAWL accounts for (1) Doppler broadening of the 
Table 3.1. Description of the processing of the master cross section library inzo ORIGEN cross sections for LWRs

\begin{tabular}{|c|c|c|c|c|}
\hline $\begin{array}{l}\text { Computer } \\
\text { ciode }\end{array}$ & Input & Function & Output & $\begin{array}{l}\text { Applicability } \\
\text { of step }\end{array}$ \\
\hline NITAWL & $\begin{array}{l}\text { 84-group master library } \\
\text { Resonance paraneters } \\
\text { Doppler temperature } \\
\text { Estimated actinide compo- } \\
\text { sition at three or four } \\
\text { burnups }\end{array}$ & $\begin{array}{l}\text { Calculazes resonance } \\
\text { self-shielding and Doppler- } \\
\text { broadening effects using } \\
\text { Nordhein integral treatment } \\
\text { for a pin cell }\end{array}$ & $\begin{array}{l}84-g \text { goup working } \\
\text { libraries at three } \\
\text { or four burnups }\end{array}$ & All L-Pu LWRs \\
\hline XSDRNPM & $\begin{array}{l}\text { 84-grcup working libraries } \\
\text { at three or four burnups }\end{array}$ & $\begin{array}{l}\text { Calculazes spatial and energy } \\
\text { self-shielding effects and } \\
\text { neutron energy spectrum asing } \\
\text { a } 1-D \text { discrete ordinates code } \\
\text { for a pin cell }\end{array}$ & $\begin{array}{l}\text { Five-group, pin- } \\
\text { cell-weighted } \\
\text { libraries at three } \\
\text { or 三our burnups }\end{array}$ & $\begin{array}{l}\text { Uranium- } \\
\text { enriched LWRs } \\
\text { only }\end{array}$ \\
\hline XSDRNPM & $\begin{array}{l}\text { 84-group working libraries } \\
\text { at three or four burnups }\end{array}$ & $\begin{array}{l}\text { Calculazes spatial self- } \\
\text { shieldiag effects and } \\
\text { neutron energy spectrum } \\
\text { lising a 1-D discrete } \\
\text { crdinat ss code for a } \\
\text { fin cell }\end{array}$ & $\begin{array}{l}84-g=\text { oup, pin-cell- } \\
\text { weighted libraries } \\
\text { at chree or four } \\
\text { burnaps }\end{array}$ & $\begin{array}{l}\text { Plutonium- } \\
\text { recycle LWRs } \\
\text { only }\end{array}$ \\
\hline XSDRNPM & $\begin{array}{l}84 \text {-group, pin-cell- } \\
\text { we-ghted libraries at } \\
\text { three or four bumups }\end{array}$ & $\begin{array}{l}\text { Calculazes spatial self- } \\
\text { shieldizg effects and } \\
\text { neutron energy spectrum } \\
\text { using a 1-D discrete } \\
\text { crdinates code for an } \\
\text { assembly }\end{array}$ & $\begin{array}{l}\text { Five-group, } \\
\text { assembly-weighted } \\
\text { libraries at three } \\
\text { or four burnups }\end{array}$ & $\begin{array}{l}\text { Plutonium- } \\
\text { recycle LWRs } \\
\text { only }\end{array}$ \\
\hline CITATION & $\begin{array}{l}\text { Five-group, pin-cell- } \\
\text { or assembly-weighted } \\
\text { libraries at three or } \\
\text { four burnups }\end{array}$ & $\begin{array}{l}\text { Five-group diffusion-theory } \\
\text { depletion and fuel } \\
\text { management }\end{array}$ & $\begin{array}{l}\text { One-zroup effective } \\
\text { libraries at many } \\
\text { burnups }\end{array}$ & Al1 U-Pu LWRs \\
\hline ORIJEN & $\begin{array}{l}\text { One-group, effeztive } \\
\text { libraries at many } \\
\text { burnups }\end{array}$ & $\begin{array}{l}\text { Zero-dimensional, one-group } \\
\text { depletion calculation fo: } \\
1300 \text { is itopes }\end{array}$ & - & A11 U-Pu LWRs \\
\hline
\end{tabular}


resonances and (2) the fact that the effect of large resonances is diminished because there are relatively few neutrons at the resonance energy. The latter effect results from the resonance itself depleting the supply of neutrons having the same energy as that of the resonance (i.e., energy self-shielding). The Nordheim integral treatment is used to account for the resonance self-shielding effects. The output of NITAWL is a multigroup cross section library (working library) in which the resonance parameters have been incorporated into the group-averaged cross sections.

\section{1 .2 XSDRNPM}

The XSDRNPM $^{1}$ computer code is effectively used to account for spatial and energy self-shielding effects within a fuel element or a fuel assembly. To do this, the code does a one-dimensional, static, $\mathrm{S}_{8} \mathrm{P}_{3}$, discreteordinates flux calculation and then uses this flux to weight the input cross section library (the working library) in space, energy, or both. This results in a cross section library which accounts for the fact that the neutron energy spectrum, and thus the effective nuclide cross sections, vary significantly within the fuel material and within the moderator. This library is designated as a "weighted library." The principal input data required are a physical description of the fuel element or assembly (i.e., the dimensions of each zone), the concentration of each nuclide within each zone, and a working library from NITAWL, corresponding to the nuclide concentrations. 


\subsubsection{CITATION}

The CITATION ${ }^{2}$ computer code is used to perform the reactor fueldepletion and fuel-management calculations using multigroup diffusion theory. The code can be used with a variety of geometries in one, two, or three dimensions. Output from CITATION includes the discharge composition of the fuel specific power and neutron flux in a particular unit of fuel as a function of burnup. Minor modifications to CITATION also allow effective cross sections for each nuclide as a function of burnup to be output for subsequent use in ORIGEN.

\subsection{Pin-Ce11 Calculations}

\subsubsection{General approach}

The so-called pin-cell calculation involves two distinct substeps. The first substep is to process the 84-energy-group master cross section library and its associated resonance parameters into an 84-group working library using the NITAWL computer code. This step accounts for Doppler broadening of the resonances and energy self-shielding. The second substep is to process the working library into a weighted library using the XSDRNPM computer code. This step accounts for the spatial selfshielding effects in the fuel element. The spatial weighting is over the entire pin cell because the cross sections will subsequently be used with nuclide densities that have been averaged over the entire pin cell. The results of this XSDRNPM pin-cell calculation are in either five energy groups, if they are to be used directly in CITATION calculations (see Sect. 3.4), or 84 energy groups, if they are to be used in subsequent XSDRNPM assembly-cell calculations (see sect. 3.3). Pin-cell calculations 
were made at three different fuel compositions for the PWRs, corresponding to burnups of 5, 16, and 27 GWd/MTIHM and at four different fuel compositions for the BWRs, corresponding to burnups of $3,10,17$, and $25 \mathrm{GWd} / \mathrm{MTIHM}$.

\subsubsection{Pin-cell description}

The pin cells for all four reactor types consisted of five concentric zones: fuel, gap, clad, moderator, and "extra." The extra zone consists of moderator, structural materials, and soluble neutron poisons not specifically associated with a particular fuel element. Examples of the types of material included in the extra zone include grid spacers, the material in water holes, fuel channels, and the moderator between fuel assemblies. A "white," or isotopic-reflecting, boundary condition was imposed on the outer boundary of the pin cells to simulate the presence of the cell in an infinite medium of other pin cells of its own type. The pin-cell dimensions for the PWR and BWR are given in Tables 3.2 and 3.3 respectively.

The nuclide number densities that are used as input to the NITAWL and XSDRNPM codes were based on depletion data ${ }^{3}$ given as a function of burnup for uranium- and plutonium-enriched PWRs and BWRs. The pin-cell calculations were made using compositions which corresponded to burnups of 5, 16, and $27 \mathrm{GWd} / \mathrm{MTIHM}$ for the PWR and 3, 10, 17, and 25 GWd/MTIHM for the BWR. These burnups were selected because they approximate the average, middle-of-cycle burnups for a PWR on a three-cycle refueling scheme with a discharge burnup of 33 GWd/MTIHM and a BWR on a four-cycle refueling scheme with a discharge burnup of 27.5 GWd/MTIHM. These burnupdependent cross section libraries were developed to account for the variation in the reactor neutron energy spectrum, and thus the effective nuclide cross sections, during the irradiation of the fuel. The calculation of the nuclide densities assumed a fuel density of $95 \%$ of the theoretical 
Table 3.2. Pin-cell dimensions for the $\mathrm{PWR}^{\mathrm{a}}$

\begin{tabular}{lcc}
\hline Region & Outer radius $(\mathrm{cm})$ & Volume fraction \\
\hline Fue1 & 0.41212 & 0.30659 \\
Cap & 0.41738 & 0.0078762 \\
Clad & 0.47572 & 0.094055 \\
Moderator & 0.71187 & 0.50626 \\
Extra & 0.74429 & 0.085219 \\
\hline $\begin{array}{l}\text { ata obtained from Westinghouse Nuclear Energy Systems, } \\
\text { RESAR-3, Reference Safety Analysis Report, DOCKET STN 50-480 } \\
(1972) .\end{array}$ &
\end{tabular}

Table 3.3. Pin-cell dimensions for the $B W R^{a}$

\begin{tabular}{lcc}
\hline Region & Outer radius $(\mathrm{cm})$ & Volume fraction \\
\hline Fuel & 0.53165 & 0.24015 \\
Gup & 0.53975 & $0.00737 / 1$ \\
Clad & 0.6270 .5 & 0.085799 \\
Moderator & 0.91845 & 0.38272 \\
ExLra & 1.08481 & 0.28321 \\
\hline a Data obtained from General Electric Standard Safety Analysis \\
Report, BWR/6, DockET STN 50-447 (1973).
\end{tabular}


and a stoichiometric amount of oxygen. For the Doppler-broadening of the resonances calculated by NITAWL, a Doppler temperature of $1000^{\circ} \mathrm{K}$ was assumed.

The concentration of the soluble boron poison in the moderator and extra zones of the PWR pin-cells was assumed to be a constant $550 \mathrm{ppm}$ for all burnups. In reality, the boron concentration varies from $\sim 1100$ ppm to $20 \mathrm{ppm}$ during each cycle. The choice of an average boron concentration for all burnups was made because later CITATION and ORIGEN calculations would not be able to account for this continuous variation. The saturated steam fraction of the water in the moderator zone for the BWR calculations was taken to be 0.392 at a pressure of 1050 psia, a value significantly lower than the volume-averaged steam fraction in the moderator zone of a modern BWR ( 0.50$).^{4}$ Similarly, the saturated steam fraction of the water in the extra zone was assumed to be 0.213 as compared to an estimated volume-averaged value of $0.353 .^{5}$ These lower steam fractions (i.e., higher water densities) were used to account for the fact that the subsequent fuel-depletion calculations were designed to simulate the "average" depletion characteristics of the reactor. Since the axial power shape in a BWR is skewed toward the bottom of the reactor because of the higher water density at the bottom. Volumeaveraging will not yield the appropriate nuclide densities. This is because the nuclide densities in low-power regions are weighted equally with those in high-power regions. Thus, a more appropriate weighting method would be to power-average the nuclide densities. Although this weighting method is made difficult because of the presence of control rods in the core, the actual power-averaged saturated steam fractions of the water in the moderator and extra zones together were estimated to be 0.365 . 
This value is comparable to the value of 0.316 , which was adjudged to give the "best" depletion results in this study, and to a volume-averaged saturated steam fraction of 0.429 . Power-averaged moderator densities are not necessary. in a PWR because the axial power shape is nearly symmetrical with respect to the reactor mid-plane, thus making poweraveraging and volume-averaging nearly equivalent. PWR nuclide densities in the moderator and extra zones were based on the properties of water at a temperature of $590^{\circ} \mathrm{F}$ and a pressure of 2250 psia.

\subsubsection{Results of pin-cell calculations}

The results of the pin-cell calculations are as follows:

1. 84- or 5-energy-group, pin-cell-averaged cross sections for the actinides, moderator, principal structural materlals, and poisons at multiple burnups;

2. 84-energy-group, pin-cel1-averaged neutron energy spectra, at multiple burnups;

3. one-group, pin-cell-averaged fission and activation product cross sections; and

4. pin-cell-averaged parameters to enable THERM, RES, and FAST values to be calculated.

The 84-energy-group cross sections are used in subsequent XSDRNPM assembly-cell calculations for the plutonium-recycle LWRs and will be discussed in Sect. 3.3. The five-energy-group cross sections are for the uranium-enriched LWRs and are used in subsequent CITATION depletion calculations described in Sect. 3.4. The nuclides in these cross section libraries are listed in Table 2.2. 
XSDRNPM also calculates a cell-averaged, 84-energy-group neutron spectrum for each of the pin-cells at each burnup. "Typical" spectra for the uranium-enriched PWR and BWR pin cells are given in Appendix A in both tabular and graphical form. The spectra for the plutonium-recycle LWRs result from the assembly-cell calculations discussed in Sect. 3.3. After the uranium-enriched LWR depletion calculations have been performed with CITATION, one of the pin cells is selected for each reactor as being representative of that reactor, based on the similarity of its neutron spectrum to that calculated by CITATION for the entire reactor. The neutron spectrum from this pin cell is used to collapse the multigroup cross sections for all nuclides listed in Tables 2.2 and 2.3 to one-group, pin-cell-averaged cross sections that are incorporated directly into the ORIGEN cross section library: These cross sections are listed in Appendix B. The collapse of these cross sections for the plutonium-recycle reactors is discussed in Sect. 3.3.

Finally, the pin cells selected for collapsing the cross sections to one group are also used to generate two sets of two neutron-energygroup cross sections and neutron spectra. These cross sections and neutron spectra are used to calculate values of THERM, RES, and FAST for the reactor being considered. The details of the methods used to calculate these values will be given in a separate publication. The results of the calculations are presented in Sect. 4.1. 


\subsection{Assembly-Cell Calculations}

\subsubsection{General approach}

The assembly-cell calculations use the XSDRNPM code and the 84energy-group, pin-cell-welghted cross sections previously produced by XSDRNPM (see Sect. 3.2.3) to determine effective cross sections and neutron energy spectra for uranium- and plutonium-enriched assemblies in plutonium-recycle LWRs. This procedure was used to account for the fact that the neutron energy spectrum on the periphery of a plutoniumenriched fuel assembly that is next to a uranium-enriched fuel assembly is different from the neutron energy spectrum in the center of either a plutonium- or uranium-enriched assembly. The assembly-cell calculations were not used for the uranium-enriched LWRs because of the relative similarity of adjacent fuel assemblies. The output cross sections from the assembly calculations are cast into a five-energy-group format that is suitable for input to CITATION after reformatting: A five-energygroup cross section set is produced for each of the burnups used in the pin-cell calculations (see Sect. 3.2.1) for both the uranium- and plutonium-enriched assemblies.

\subsubsection{Assembly-ce11 description}

The assembly cells for all of the assembly calculations consisted of two concentric zones: an inner, homogenized mixture representing the fuel assembly of interest and an outer, homogenized mixture representing the composition of a mixture of uranium- and plutonium-enriched fuel assemblies. The inner zone is the size of one cylindricized fuel assembly, whereas the outer zone is simply made large enough to establish 
a neutron energy spectrum. The resulting radii of these two zones were 12.08 and $22.08 \mathrm{~cm}$, respectively, for the PWR and 7.564 and $17.564 \mathrm{~cm}$, respectively, for the BWR. An isotropic-reflecting boundary condition was used at the outer boundary. The composition of the inner zone was equivalent to that obtained by homogenizing (volume-weighting) the pincell compositions described in Sect. 3.2.2. The composition of the outer zone corresponded to that of a homogenized, middle-of-cycle pin cell which was $30 \%$ plutonium-enriched and $70 \%$ uranium-enriched.

\subsubsection{Results of assembly-cell calculations}

The results of the assembly-cell calculations for the plutoniumrecycle LWRs are as follows:

1. five-energy-group, inner-zone-averaged cross sections for the actinides, principal structural materials, and poisons at multiple burnups;

2. 84-energy-group, inner-zone-averaged neutron spectra at multiple burnups;

3. one-group, inner-zone-averaged fission product, activation product, and actinide cross sections at one burnup; and

4. inner-zone-averaged parameters to enable THERM, RES, and FAST values to be calculated.

The five-energy-group, assembly-cell-averaged cross sections (i.e., weighted libraries) are used as input to the CITATION computer code. There are six weighted libraries for the plutonium-recycle PWR - three for the uranium-enriched assembly, corresponding to burnups of 5,16 , and $27 \mathrm{GWd} / \mathrm{MTIHM}$, and three for the plutonium-enriched assembly, corresponding to the same burnups. There are eight weighted libraries 
for the plutonium-recycle BWR - four each for the uranium- and plutoniumenriched assemblies, corresponding to burnups of 3, 10, 17, and 25 GWd/MTIHM. The nuclides in these weighted libraries are listed in Table 2.2.

Typical neutron-energy spectra calculated by the XSDRNPM code for uranium- and plutonium-enriched fuel assemblies in both the PWR and BWR are listed in Appendix A. These spectra correspond to a single burnup for each reactor that was selected because of the similarity of its neutron spectrum to that calculated by CITATION during the depletion calculations described in Sect. 3.4 .

These same neutron spectra are used to collapse cross sections for the actinides listed in Table 2.2 and the nuclides listed in Table 2.3 to one-group, assembly-cell-averaged cross sections that are incorporated directly into the ORIGEN cross section 1ibrary. These cross sections are listed in Appendix B.

Finaily, the same assembly cells selected for collapsing the multigroup cross sections to one group are rerun to generate two sets of two neutron-energy-group cross sections and neutron spectra that are used to calculate values of THERM, RES, and FAST for each fuel type being considered. The details of the methods used to calculate these values will be given in a separate publication. The results of the calculations are presented in Sect. 4.1. 


\subsection{Fuel-Depletion Calculations}

\subsubsection{General approach}

The purpose of performing a multigroup fuel-depletion calculation with the CITATION computer code was to model the depletion characteristics of an entire batch of reactor fuel at steady state. Hence for the purposes of updating the ORIGEN computer code, spatial details of the depletion are not 1mportant. Therefore, the basic approach taken was to use the simplest neutronic and fuel management model possiblc while still obtaining adequate depletion results. As is evident from the preceding sections, five-energy-group cross section sets were employed. The energy boundaries of this five-group structure are given in Table 3.4. This group structure consists of one thermal group and four fast groups spanning the energy range of $1.0 \times 10^{-5}$ to $10.0 \mathrm{MeV}$. Early in the planning stages of the ORIGEN update effort, discussions ${ }^{6}$ indicated that the neutronic interaction of the fuel assemblies with differing burnups would have an important effect on the results of the depletion calculation. Therefore, it was decided that the spatial order of the CITATION calculations would be kept as low as possible and that the simultaneous presence of fuel with different burnups would be accounted for in the fuel management scheme. This led to the selection of zero-dimensional, three- and four-region CITATION models for the uranium-enriched PWR and BWR, respectively, and two-dimensional, sixand eight-region models for the plutonium-recycle PWR and BWR, respectively. 
Table 3.4. CITATION cross section energy-group structure

\begin{tabular}{llc}
$\begin{array}{l}\text { Group } \\
\text { number }\end{array}$ & $\begin{array}{c}\text { Upper boundary } \\
(\mathrm{eV})\end{array}$ & $\begin{array}{c}\text { Lower boundary } \\
(\mathrm{cV})\end{array}$ \\
\hline 1 & $1.00000 \times 10^{7}$ & $5.53084 \times 10^{3}$ \\
2 & $5.53084 \times 10^{3}$ & $2.90232 \times 10^{1}$ \\
3 & $2.90232 \times 10^{1}$ & $1.85539 \times 10^{0}$ \\
4 & $1.85539 \times 10^{0}$ & $6.32500 \times 10^{-1}$ \\
5 & $6.32500 \times 10^{-1}$ & $1.00000 \times 10^{-5}$ \\
\hline
\end{tabular}

\subsubsection{CITATION depletion model description}

3.4.2.1 Uranium-enriched LWRs. The relative neutronic homogeneity of the uranium-erniched LWRs allowed the use of spatial models that were effectively zero-dimensional. More specifically, the spatial model used was a one-dimensional, three-region (PWR) or tour-region (BWK) slab with reflecting boundary conditions. The zero-dimensionality characteristic was achieved by making the volumes of each of the regions very small $\left(0.001 \mathrm{~cm}^{3}\right)$, thus forcing the neutron flux to be flat and have the same energy distribution over all three zones. In the PWR model, the first, second, and third regions were assigned cross sections corresponding to fuel burnups of 5, 16, and $27 \mathrm{GWd} / \mathrm{MTIHM}$, respectively. Similarly, the four regions in the BWR model are assigned cross section sets corresponding to $3,19,17$, and 25 GWd/MTIHM. The reload fuel is charged to the region that has been assigned the cross sections which correspond to the lowest burnup and is then irradiated for 293.3 full-power days for the PWR or 265.4 full-power days for the BWR. This somewhat depleted fuel composition 
is then moved to the region that has been assigned cross sections which correspond to the next higher burnup and is irradiated for another 293.3 or 265.4 full-power days while a fresh batch of fuel is irradiated in the vacated region. This process is continued for ten cycles, at which time the discharge composition of the fuel reaches a nearly constant value. Schematic depictions of the steady-state fuel management models for the uranium-enriched PWR and BWR are given in Figs. 3.2 and 3.3, respectively.

The models described above require some type of initial loading to begin the calculations. The three regions in the PWR model are initially loaded with fuel having enrichments of $3.1,2.6$, and 2.1 wt $\%$ ${ }^{235} \mathrm{U}$. In the $\mathrm{BWR}$ model, one region is initially loaded with fuel having a uranium enrichment of 1.1 wt $\%{ }^{235} \mathrm{U}$; the remaining regions contain fuel having a uranium enrichment of 2.5 wt $\%{ }^{235} \mathrm{U}$. All reload batches have uranium enrichments of 3.2 wt \% for the PWR and 2.75 wt \% for the BWR. During the first cycle, cross sections were altered from the assignments described previously in that all regions were assigned cross sections which corresponded to the lowest burnup for the reactor.

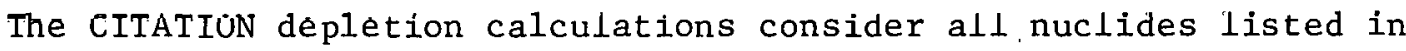
Table 2.2 explicitly. All nuclide densities input to CITATION are pince11 or assemb1y-cel1-averaged quantities.

The power-level input to CITATION is equivalent ot a specific power of $37.5 \mathrm{MW} / \mathrm{MTIHM}$ for the PWR and $25.9 \mathrm{MW} / \mathrm{MTIHM}$ for the BWR. The specific power of each batch of fuel in the CITATION models varies throughout its life, depending on its enrichment and the enrichment of the other fuel in the model at that time. 


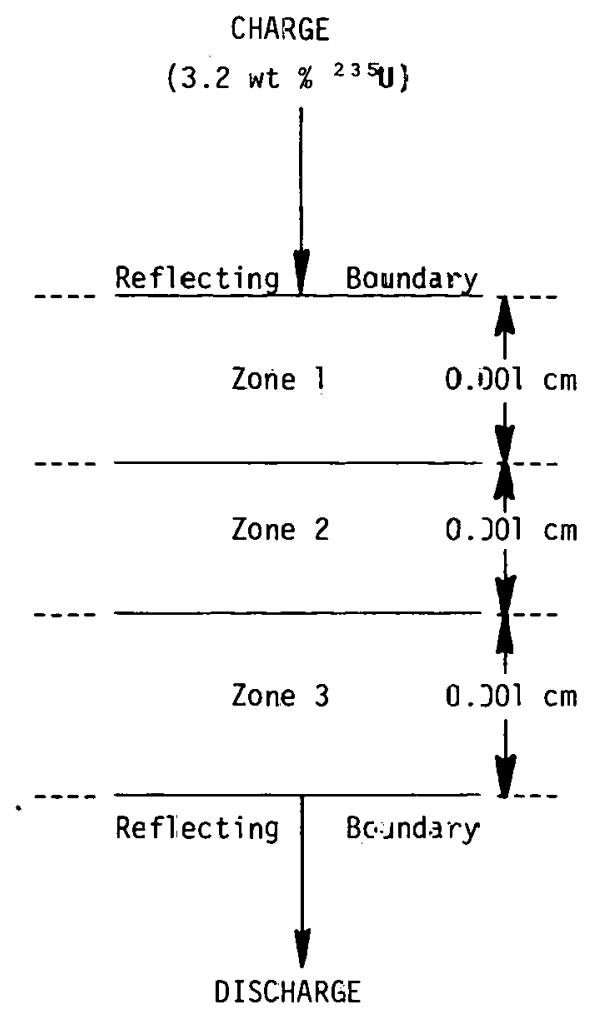

( 33 GWd/MTHMi)

\begin{tabular}{|c|c|c|c|c|}
\hline Zone & $\begin{array}{l}\text { Fue burnup at } \\
\text { which cross sections } \\
\text { were de termined } \\
\text { (GWd/MTHM) }\end{array}$ & $\begin{array}{l}\text { Status of fuel } \\
\text { at beginning } \\
\text { of cyile }\end{array}$ & $\begin{array}{l}\text { status of fuel } \\
\text { at end of } \\
\text { cycle }\end{array}$ & $\begin{array}{l}\text { Disposition of } \\
\text { zone at end } \\
\text { of cycle }\end{array}$ \\
\hline $\mathrm{i}$ & 5 & Fres? & $\begin{array}{l}\text { Irradiated } \\
\text { one cycle }\end{array}$ & Move to Zone 2 \\
\hline 2 & 16 & $\begin{array}{l}\text { Irradiated } \\
\text { one cy=le }\end{array}$ & $\begin{array}{l}\text { Irradiated } \\
\text { two cycles }\end{array}$ & Move to Zone 3 \\
\hline 3 & 27 & $\begin{array}{l}\text { Irradizted } \\
\text { two cy=les }\end{array}$ & $\begin{array}{l}\text { Irradiated } \\
\text { three cycles }\end{array}$ & Discharge \\
\hline
\end{tabular}

NOTES: 1. Cycle length is 293.3 full-pewer days.

2. 0ne-dimensional slab yeometry: used; the small thicknesses of the slabs $(=) .001 \mathrm{~cm})$ effectively make this a zero-dimensional calculation.

Iig. 3.2. CITATION fuel management model for the uranium-enriched PWR ( (IWR-U) after the first cycle. 
ORNL-DWG 78-13740

CHARGE

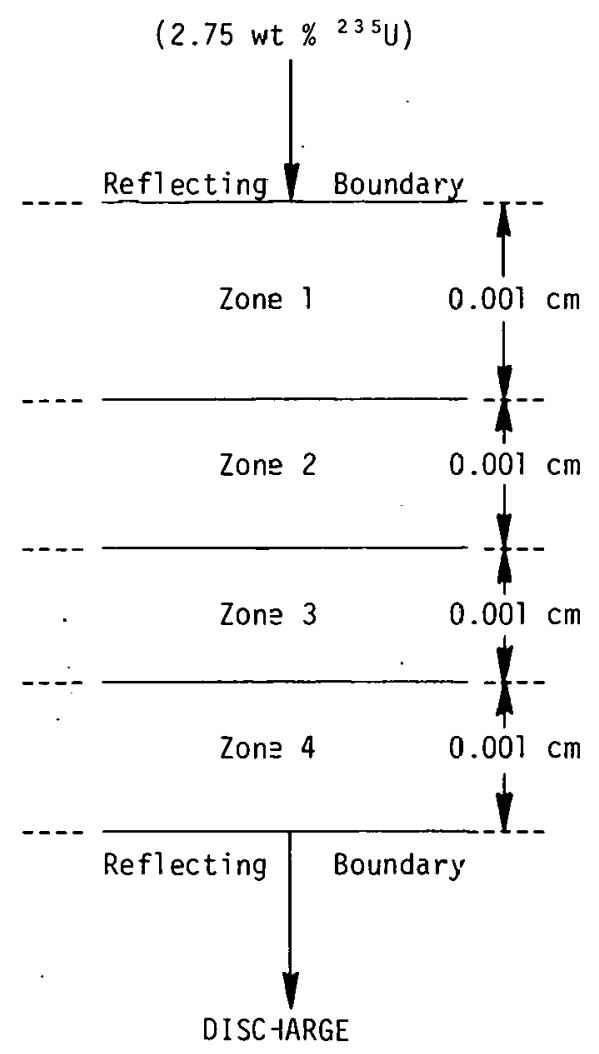

(27.5 GNd/MTHM)
BWR-U Fuel Management Description

\begin{tabular}{|c|c|c|c|c|}
\hline Zone & $\begin{array}{l}\text { Fuel burn:sp at } \\
\text { which cross sections } \\
\text { were determined } \\
\text { (GWd/MTHM) }\end{array}$ & $\begin{array}{l}\text { Status of fuel } \\
\text { at beginning } \\
\text { of cycle }\end{array}$ & $\begin{array}{l}\text { Status of fuel } \\
\text { at end of } \\
\text { cycle }\end{array}$ & $\begin{array}{c}\text { Disposition of } \\
\text { zone at end } \\
\text { of cycle }\end{array}$ \\
\hline 1 & 3 & Fresh & $\begin{array}{l}\text { Irradiated } \\
\text { one cycle }\end{array}$ & Move to Zone 2 \\
\hline 2 & $10^{\circ}$ & $\begin{array}{l}\text { Irradiated } \\
\text { one cycle }\end{array}$ & $\begin{array}{l}\text { Irradiated } \\
\text { two cycles }\end{array}$ & Move to Zone 3 \\
\hline 3 & 17 & $\begin{array}{l}\text { Irradiated } \\
\text { two cycles }\end{array}$ & $\begin{array}{l}\text { Irradiated } \\
\text { three cycles }\end{array}$ & Move to Zone 4 \\
\hline 4 & 25 & $\begin{array}{l}\text { Irradiated } \\
\text { three cycles }\end{array}$ & $\begin{array}{l}\text { Irradiated } \\
\text { four cycles }\end{array}$ & Discharge \\
\hline
\end{tabular}

NOTES: 1. Cycle length is 265.4 full-power days.

2. One-dimensional slab geometry used; the small thicknesses of the slabs $(=0.001 \mathrm{~cm})$ effectively make this a zero-dimensional calculation.

Fig. 3.3. CITAT-ION fuel management model for the aranium-enriched BWR (BWR-U) after the first cycle. 
3.4.2.2 Plutonium-recycle LWRs. The significant neutronic differences between ${ }^{235} \mathrm{U}$ and the fissile plutonium isotopes $\left({ }^{239} \mathrm{Pu}\right.$ and $\left.{ }^{241} \mathrm{Pu}\right)$ indicate that the cross sections used for uranium-enriched fuel must be different from those of plutonium-enriched fuel if the depletion calculations are to be accurate. Furthermore, the fact that LWR fuel assemblies are large when compared to the neutron mean free path in the reactor means that significant changes in the neutron spectrum can be expected between the periphery and the center of a plutonium-enriched assembly located next to a uranium-enriched assembly. These considerations require that that CITATION model used for depleting fuel in a plutonium-recycle LWR be greater than zero-dimensional to account for the spatial variation in neutron spectrum and flux. The model used was a two-dimensional, sixregion (PWR) or eight-region (BWR) slab with a periodic boundary condition on the right and left and a reflecting boundary condition on the top and bottom. Half of the regions in each reactor were assumed to be pilutonlumenriched, and half were assumed to be uranium-enriched. The fuel management and cross section assignment models used are analogous to those described in Sect. 3.4.2.1 and are depicted in Figs. 3.4 and 3.5. As noted above and described in Sect. 3.2 and 3.3, a different cross section set is used for each region of the model. The fuel management scheme is countercurrent in order to reduce power-peaking during the depletion calculation. The volume of each pair of plutonium- plus uranium-enriched regions was considered to be identical to that of a fuel assembly for the reactor being considered. The volume of the uranium-enriched regions was assumed to be larger than the volume of the plutonium-enriched regions by the ratio of the amount of uranium-enriched fuel to plutonium-enriched fuel 
ORNL DWG 78-13741

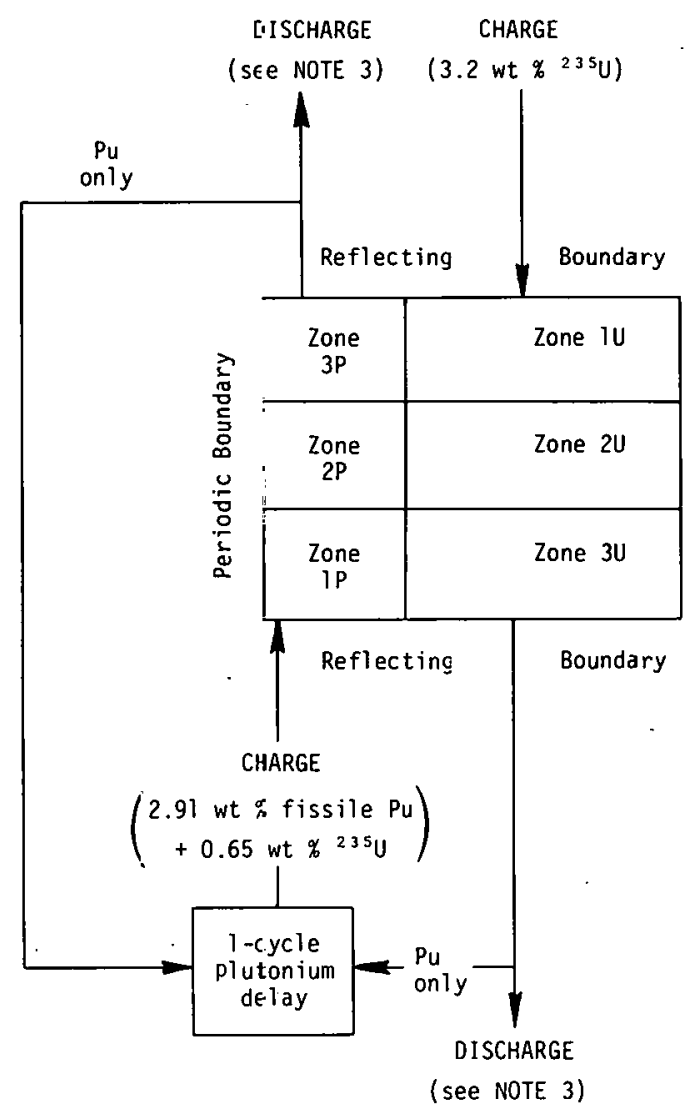

\begin{tabular}{|c|c|c|c|c|c|}
\hline & & PWR-P & el Management De & iption & \\
\hline & Zone & $\begin{array}{l}\text { Fuel burnup at } \\
\text { which cross sections } \\
\text { were determined } \\
\text { (GWd/MTHM) }\end{array}$ & $\begin{array}{l}\text { Status of fuel } \\
\text { at beginning } \\
\text { of cycle }\end{array}$ & $\begin{array}{l}\text { Status of fuel } \\
\text { at end of } \\
\text { cycle }\end{array}$ & $\begin{array}{c}\text { Disposition of } \\
\text { zone at end } \\
\text { of cycle }\end{array}$ \\
\hline & $1 U(I P)$ & 5 & Fresh & $\begin{array}{l}\text { Irradiated } \\
\text { one cycle }\end{array}$ & $\begin{array}{c}\text { Move to } \\
\text { Zone } 2 U(2 P)\end{array}$ \\
\hline & $2 U(2 P)$ & 16 & $\begin{array}{l}\text { Irradiated } \\
\text { one cycle }\end{array}$ & $\begin{array}{l}\text { Irradiated } \\
\text { two cycles }\end{array}$ & $\begin{array}{l}\text { Move to } \\
\text { Zone } 3 U(3 P)\end{array}$ \\
\hline & $3 U(3 P)$ & 27 & $\begin{array}{l}\text { Irradiated } \\
\text { two cycles }\end{array}$ & $\begin{array}{l}\text { Irradiated } \\
\text { three cycles }\end{array}$ & $\begin{array}{l}\text { Discharge; } \\
\text { Pu recycled }\end{array}$ \\
\hline
\end{tabular}

NOTミS: : Cycle length is 293.3 full-power days.

2. Two-dimensional $X-Y$ geometry used; "U" zones are $15.12 \times 21.0 \mathrm{~cm}$, and "P" zones are $5.88 \times 21.0 \mathrm{~cm}$.

3. Weighted-average burnup of " $U$ " and "P" discharged fuel is 33 GWd/MTHM.

Fig. 3.4. CITATION fuel management model for the plutonium-recycle PWR (PWR-Pu) after the first cycle. 


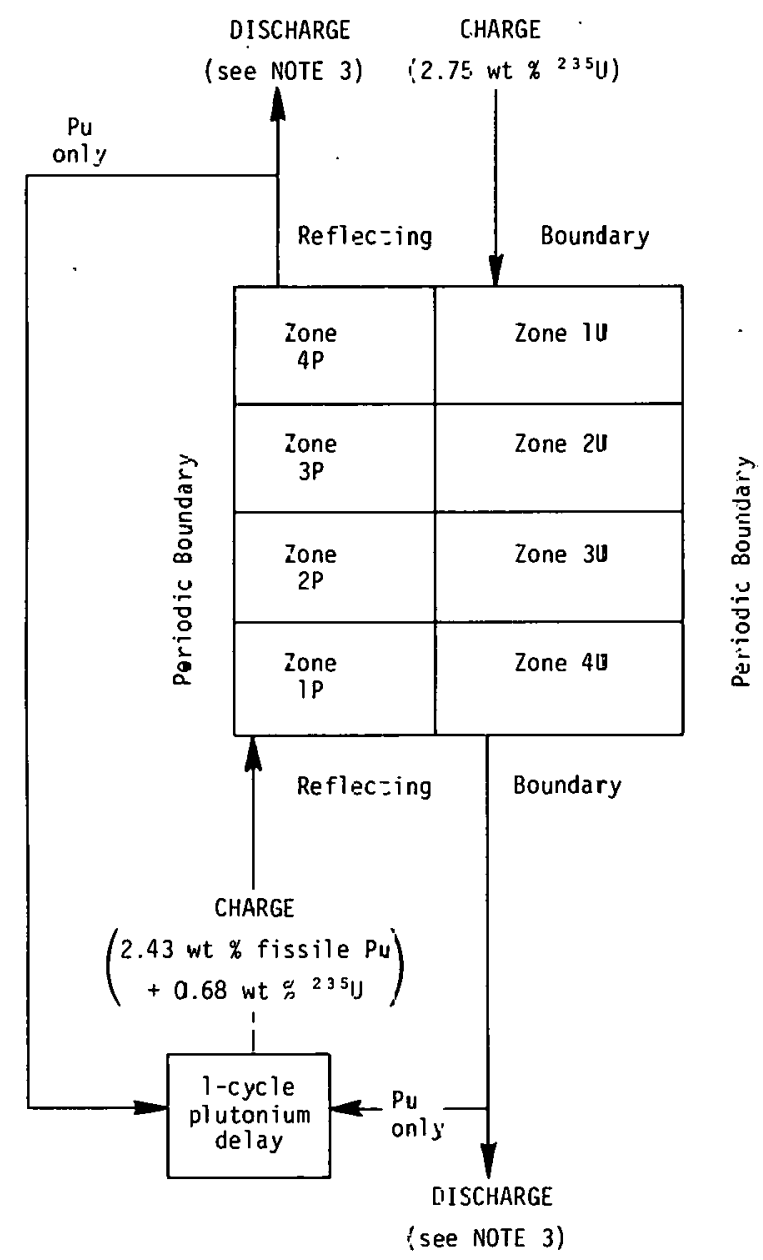

BWR-Pu Fuel Manageneent Description

\begin{tabular}{|c|c|c|c|c|}
\hline Zore & $\begin{array}{l}\text { Fuel burnup at } \\
\text { which cross sections } \\
\text { were determined } \\
\text { (GNd/MTHM) }\end{array}$ & $\begin{array}{l}\text { Status of fuel } \\
\text { at beginning } \\
\text { of cycle }\end{array}$ & $\begin{array}{l}\text { Status of fuel } \\
\text { at end of } \\
\text { cycle }\end{array}$ & $\begin{array}{l}\text { Disposition of } \\
\text { zone at erid } \\
\text { of cycle }\end{array}$ \\
\hline (Pרן: $1(1)$ & 3 & Fresh & $\begin{array}{l}\text { Irradiated } \\
\text { one cycle }\end{array}$ & $\begin{array}{c}\text { Move to } \\
\text { Zone } 2 U(2 \mathrm{U})\end{array}$ \\
\hline $2 U(2 P)$ & 10 & $\begin{array}{l}\text { Irradiated } \\
\text { one cycle }\end{array}$ & $\begin{array}{l}\text { Irradiated } \\
\text { two cycles }\end{array}$ & $\begin{array}{c}\text { Move tc } \\
\text { Zone } 3 U(\mathrm{SP})\end{array}$ \\
\hline $3 U(3 P)$ & 17 & $\begin{array}{l}\text { Irradiated } \\
\text { two cjcles }\end{array}$ & $\begin{array}{l}\text { Irradiated } \\
\text { three cycles }\end{array}$ & $\begin{array}{cl}\text { Move tc } & \text { tc } \\
\text { Zone } 4 U(4 P)\end{array}$ \\
\hline $40 \quad .7 P)$ & 25 & $\begin{array}{l}\text { Irradiated } \\
\text { three cycles }\end{array}$ & $\begin{array}{l}\text { Irradiated } \\
\text { four cycles }\end{array}$ & $\begin{array}{l}\text { Discharge; } \\
\text { Pu recycled }\end{array}$ \\
\hline
\end{tabular}

NOTES: 1. Cycle 1 ength is 265.4 full-power days

2. Two-dimensionā $X-Y$ geonetry used; "U" zanes are $9.12 \times 13.41 \mathrm{~cm}$, anc " zones are $4.29 \times i 3.41 \mathrm{~cm}$.

3. Weighted-averäge burnup of " $U$ " andl "P" discharged fuel is 27.5 GWd/MTHM.

Fig. 3.5. CITATION fuel management model for the plutonium-recycle BWR (BWR-Pu) after the first czcle. 
in the reactor after the second-plutonium recycle. This ratio is $72 / 28$ for the PWR and 68/32 for the BWR. The entire reactor is assumed to be uranium-enriched initially with the same initial compositions as those used for the uranium-enriched LWRs (see Sect. 3.4.2.1). The plutonium from both the uranium- and plutonium-enriched regions was assumed to be recycled to the plutonium-enriched regions after a one-cycle, out-of-reactor delay. The CITATION depletion calculation was terminated after the second complete plutonium recycle, which corresponded to 11 cycles for the PWR and 14 cycles for the BWR. As with the uranium-enriched reactors, the reactor-average specific powers were assumed to be $37.5 \mathrm{MW} / \mathrm{MTIHM}$ for the PWR and 25.9 MW/MTIHM for the BWR.

\subsubsection{Results of CITATION depletion calculations}

The results of the CITATION depletion calculations for uranium- and plutonium-recycle LWRs are as follows:

1. one-energy-group, effective cross sections for the nuclides listed in Table 2.2 , as a function of burnup;

2. the discharge composition of various LWR reactor fuels; and

3. five-group neutron spectra as a function of burnup.

The one-energy-group, effective cross sections of the principal actinides are reformatted and incorporated into the ORIGEN computer code as a function of burnup as described in Sect. 4.1. The PWR-U and PWR-PuPu cross sections incorporated into ORIGEN in this manner are listed in Appendix C.

The discharged composition of the fuels is used as a basis of comparison to ensure that ORIGEN depletion calculations are correct. This consideration will be discussed further in Sect. 4. 
The five-energy-group neutron spectra are used as a basis for selecting one of the cell calculations described in Sects. 3.2 and 3.3 to provide collapsed, one-energy-group cross sections for the fission products, activation products, and actinides for incorporation into the ORIGEN cross section library.

It should be noted that two sets of the results listed above are produced for each plutonium-recycle LWR (one for the uranium-enriched fuel and one for the plutonium-enriched fuel).

\section{3.j Axial Neutron Energy Spectrum Calculations}

\subsubsection{General approach}

Axial spectrum calculations were performed for uranium-enriched PWR and BWR fuel assemblies with the XSDRNPM computer code to provide information concerning the neutron flux level and spectrum outside the active fuel region of the core. These calculations are usetul in determining the degree to which the fuel plenum springs and fuel-assembly end pieces become activated.

\subsubsection{Axial assembly model}

The axial assembly model for the PWR consisted of 12 one-dimensional zones, each with a nuclide composition corresponding to one vertical segment of the fuel assembly. The fuel composition corresponded to that at middle-of-cycle and was assumed to be uniform throughout the active fuel region. The moderator density was assumed to be $0.7283 \mathrm{~g} / \mathrm{cm}^{3}$ throughout the entire assembly and to contain 550 ppm of boron. The dimensions and material makeup of each of the 12 PWR axial assembly zones are given in Table 3.5. 
Table 3.5. Dimensions and material makeup of the PWR axial assembly model

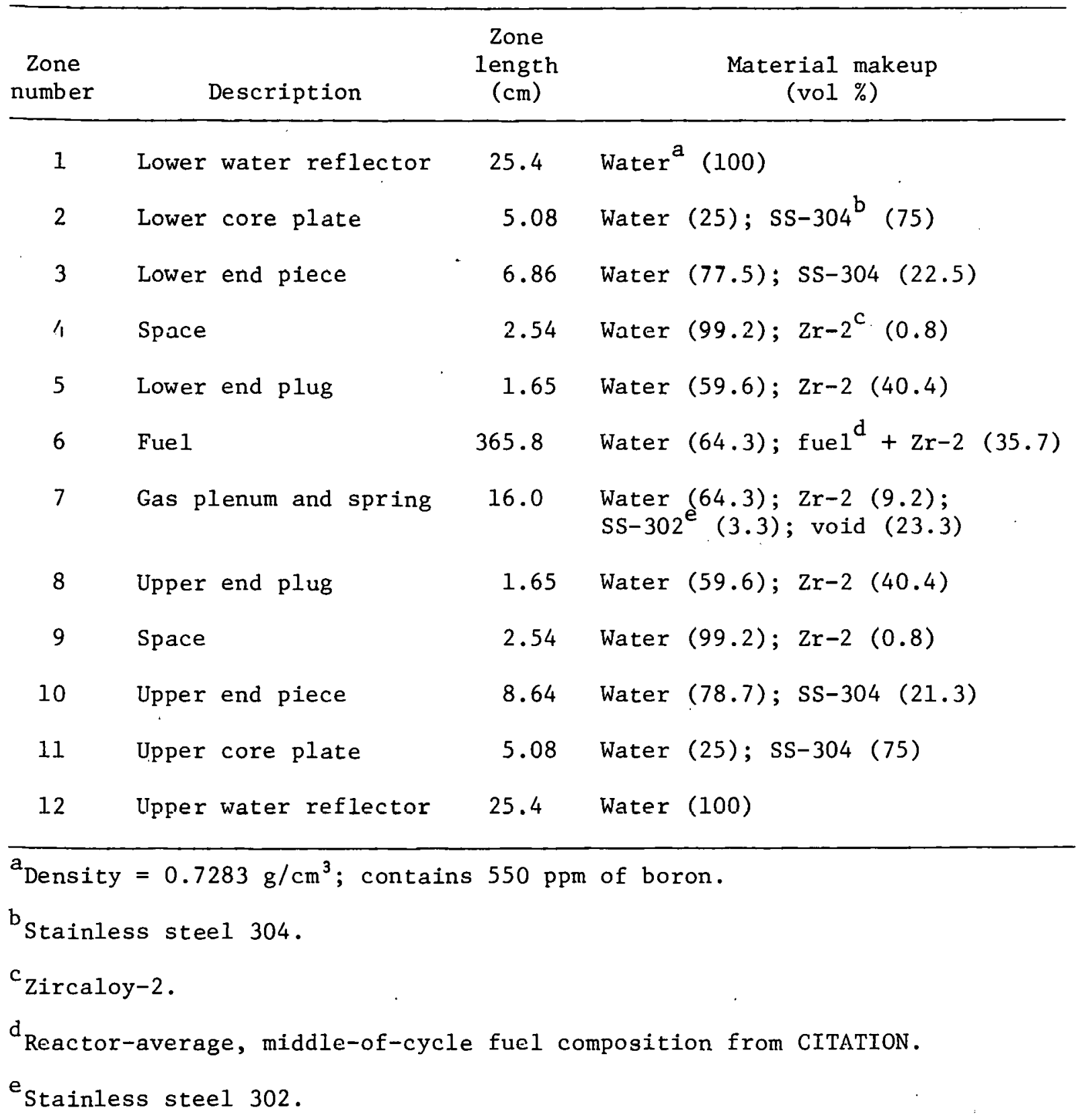


The axial assembly model for the BWR consisted of 16 one-dimensional zones. The fuel composition corresponded to that of middle-of-cycle and was assumed to be uniform throughout the active fuel region. The moderator density was assumed to vary in the active fuel region, corresponding to the axial change in void fraction as given in ref. 4. The dimensions and material makeup of each of the $16 \mathrm{BWR}$ axial assembly zones are given in Table 3.6 .

\subsubsection{Results of the axial spectrum calculations}

The desired result of the axial spectrum calculations is the ratio of the activation of selected structural materials in the end pieces and plenum springs to the activation of the same materials in the active fuel zone (i.e., an activation ratio). When this ratio is multiplied by the average neutron flux in the active fuel zone, the resulting value is the correct flux to use when irradiating the structural materials using the one-group cross sections obtained from XSDRNPM (Sects. 3.2.3 and 3.3 .3$)$. The activation ratios resulting from the uranium-enriched PWR and BWR spectrum calculations are summarized in Table 3.7. Activation ratios for the fuels in plutonium-recycle PWRs and BWRs were calculated by multiplying the corresponding uranium-enriched reactor activation ratio by the ratio of FAST for the new fuel type to FAST for the uranium-enriched reactor (see Sect. 4.1 for a discussion of FAST). This procedure was used because it is the fast (high-energy) neutrons that have the ability to reach the structural materials outside the core before being captured. The large difference in the activation ratios of the PWRs and the BWRs is a result of the soluble boron neutron poison assumed to be present in the PWR moderator, which effectively reduces the neutron flux. 
Table 3.6. Dimensions and material makeup of the BWR axial assembly model

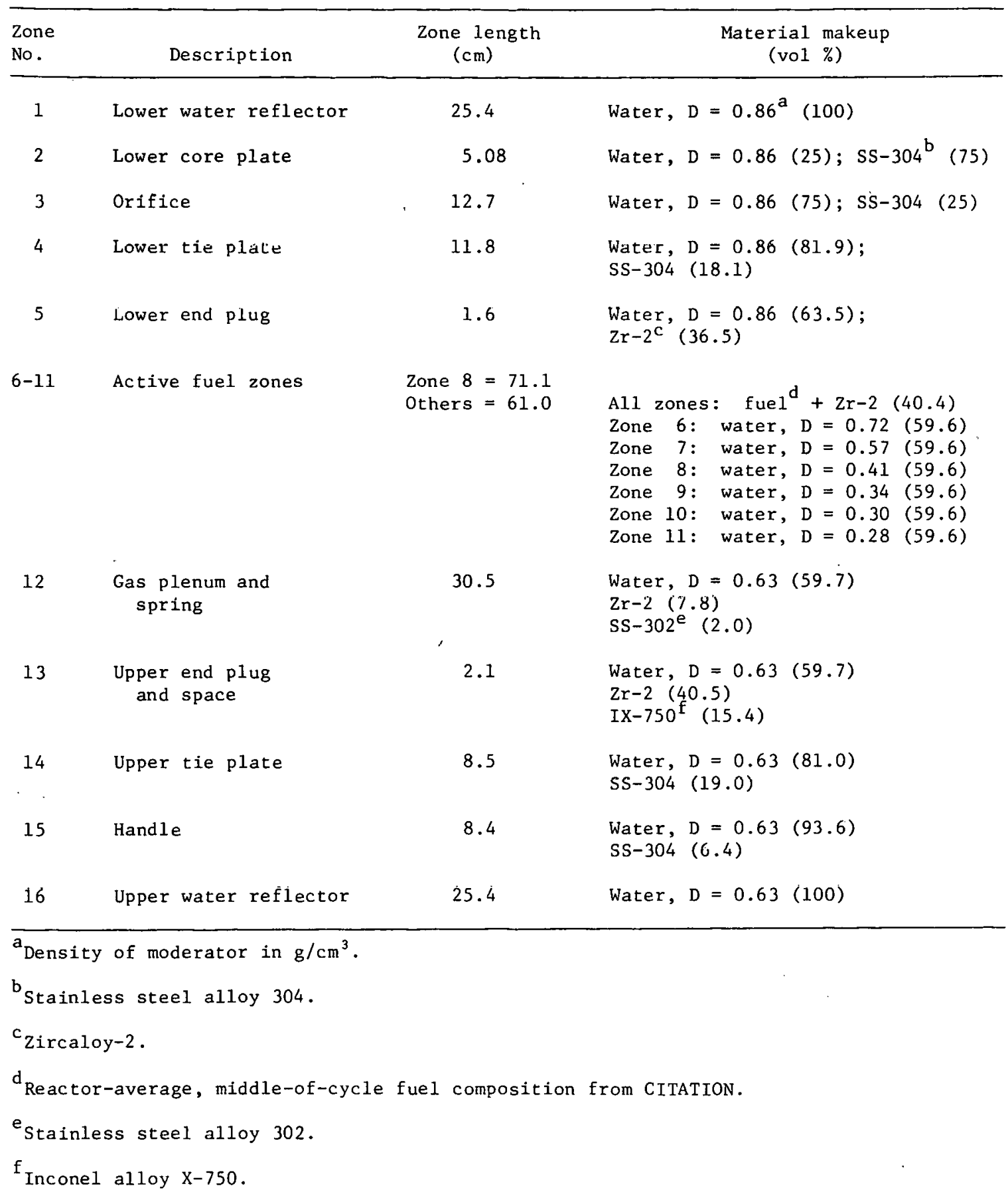


Table 3.7. Summary of the results of the axial spectrun calculations

\begin{tabular}{|c|c|c|c|c|c|c|}
\hline & FWR-U & $\mathrm{PWR}-\mathrm{PuU}^{\mathrm{a}}$ & $\mathrm{PWR}-\mathrm{PuPu}{ }^{\mathrm{a}}$ & BWR-U & $\mathrm{BWR}-\mathrm{PuU} \mathrm{b}^{\mathrm{b}}$ & $\mathrm{BWR}-\mathrm{PuPu}{ }^{b}$ \\
\hline \multicolumn{7}{|c|}{ Activation ratios ${ }^{c}$} \\
\hline End pieces ${ }^{d}$ & 0.011 & 0.011 & 0.013 & 0.130 & 0.131 & 0.142 \\
\hline Plenum springs & 0.042 & 0.043 & 0.048 & 0.500 & 0.505 & 0.545 \\
\hline \multicolumn{7}{|c|}{$\begin{array}{l}\text { Fraction of amount } \\
\text { actually. preser.t } \\
\text { to be usec in } \\
\text { ORIGEN }\end{array}$} \\
\hline $\mathrm{Fe}, \mathrm{Ni}, \mathrm{Cr}$ & 1.0 & 1.0 & 1.0 & 1.0 & 1.0 & 1.0 \\
\hline Mn & 0.80 & 0.80 & 0.80 & 0.80 & 0.80 & 0.80 \\
\hline Do & 0.67 & 0.67 & 0.67 & 0.67 & 0.67 & 0.67 \\
\hline $\mathrm{Zr}$ & 0.40 & 0.40 & 0.40 & 0.32 & 0.32 & 0.32 \\
\hline
\end{tabular}

${ }^{a}$ Activation ratios based on PWR-U axial spectrum calculation and ratio of FAST parameter (see Sect. 4.1); the fraction of the elenents to be used in ORIGEN is assumed to be constant for all PWRs.

${ }^{b}$

Altivation ratic based on BWR-U axial spectrum calculation and ratio of FAST parameter (see Sect. 4.1); the fraction of the elenents to be used in ORIGEN is assumed to be constant for all BWRs.

${ }^{c}$ Ratio of element activation in the specified material and location to the element activation for the same material in the active fuel zone.

dAverage of upper and lower end pieces. 
A second important result of the axial spectrum calculations is that, because of the changes in the neutron spectrum outside the active fuel zone, the effective cross sections of the structural materials change, to varying degrees, from their values in the active fuel zone. The effect of these cross section changes can be accounted for in ORIGEN by altering the amount of the element assumed to be initially present to a value other than the amount that would actually be present. Fortuitously, the effective crsos sections of the three major constituents of the stainless steel end pieces and plenum springs - iron, nickel, and chromium - all change to the same extent. Thus, these elements can be assumed to be present initially in their actual quantities. This fact is reflected in the portion of Table 3.7 labelled "fraction of amount actually present to be used in ORIGEN." However, the effective cross sections of three other constituents of the structural materials (manganese, cobalt, and zirconium) decrease to a greater extent than the cross sections of iron, nickel, and chromium in the neutron spectrum outside the active fuel region, thus requiring that the amount assumed to be present initially in ORIGEN be less than that actually present if the activation calculation is to be correct. The fraction of these three elements that should be input to ORIGEN to yield the correct activation is also indicated in Table 3.7. This fraction appears to be strongly correlated with the ratio of the thermal cross section to the resonance integral for the element of interest. 


\subsection{References for Sect. 3}

1. N. M. Greene, J. L. Lucius, L. M. Petrie, W. E. Ford III, J. E. White, and R. Q. Wright, AMPX: A Modular Code System for Generating Coupled Multigroup Neutron-Gamma Libraries from ENDF/B, ORNL/TM-3706 (March 1976).

2. T. B. Fowler, D. R. Vondy, and G. W. Cunningham, Nuclear Reactor Core Analysis Code: CITATIUN, ORÑL/TM-2496, Rev. 2 (July 1971).

3. Pacific Northwest Laboratories, Theoretical Analysis of Plutonium Buildup and Uranium Depletion in Pressurized Water and Boiling Water. Power Reactors, Report Y49024 to IAEA Division of Nuclear Power Reactors (July 1968).

4. General Electric Standard Safety Analysis Report, BWR/6, DOCKET STN 50-447 (1973).

5. W. B. Arthur, Union Carbide Nuclear Division, personal communication to A. G. Croff, Oak Ridge National Laboratory, January 1977.

6. D. R, Vondy, Oak Ridge National Laboratory, personal communication to A. G. Croff, Oak Ridge National Laboratory, September 1976. 


\section{DESCRIPTION OF REACTOR MODELS}

The results of the reactor physics calculations described in Sect. 3 were specifically developed to provide the neutronic and cross section data required by the ORIGEN computer code. However, the full incorporation of new U-Pu cycle LWR models into ORIGEN requires the results of work not directly involved with the reactor physics calculations. The additional work can be broken down into four major categories: (1) modification of the ORIGEN code to eliminate assumptions that are incompatible with the new cross sections, (2) specification of the initial structural material and fuel compositions, (3) comparison of ORIGEN fue1-depletion calculations with independent calculations to validate the new reactor models, and (4) a summary description of the new reference reactor models.

The required ORIGEN computer code modifications involve (1) allowing the recoverable energy per fission to be dependent on the fissile species involved, (2) redefining the ORIGEN neutron spectrum parameters THERM, RES, and FAST on a total flux basis instead of a thermal flux basis, and (3) allowing the cross sections of the principal actinides (i.e., 234-236,238 $\mathrm{U}, 238-242 \mathrm{Pu},{ }^{241,243} \mathrm{Am}$, and $242,244 \mathrm{Cm}$ ) to be a function of fue1 burnup. These modifications are discussed further in sect. 4.1. The specification of the input compositions to ORIGEN involves a literature search to determine (1) the mass and elemental composition (including minor constituents) of the structural metals in a fuel assembly, (2) the trace element composition of oxide fuel pellets, and (3) the heavy-metal isotopic composition of the fuel. These compositions are presented and discussed in Sect. 4.2 . 
A comparison of the spent fuel compositions predicted by the revised reactor models with independent calculations is required since the relative simplicity of the multigroup depletion (i.e., CITATION) models does not necessarily indicate an accurate result even when ORIGEN results agree well with CITTATION results. The results of depletion calculations were obtained from the literature, and ORIGEN depletion calculations were performed on a basis consistent with each literature reference. These two results are presented together in a series of tables in Sects. 4.3.1 and 4.3.2. In general, agreement was very good, although significant discrepancies were noted in the case of BWR-PuPu fuel.

A summary description of the results of ORIGEN fuel-depletion calculations for the U-Pu cycle LWRs is given in Sect. 4.3.3.

\subsection{Discussion of ORIGEN Modifications}

l'he incorporation of cross sections derlved from sophlsctcaced reactor physics codes into ORIGEN necessitates modifications to ORIGEN if its depletion calculations are to agree with the more sophisticated calculations. Although recent ORIGEN modifications (to be described in later publications) have been relatively extensive, only three basic changes are required in the existing version of ORIGEN $^{1}$ so that the cross sections from more sophisticated reactor physics codes may be used:

1. The present assumption that the recoverable energy per fission is a constant $200 \mathrm{MeV}$ per fission must be relaxed to account for the variation in this parameter for various actinides.

2. The values of THERM, RES, and FAST, used to calculate effective, one-group cross sections from $2200-\mathrm{m} / \mathrm{sec}$ cross 
sections, resonance integrals, and threshold cross sections, respectively, must be redefined and recalculated.

3. The assumption that the cross sections of the actinides present in relatively high concentrations in the reactor fuels are constant must be relaxed to account for the significant variation of these cross sections during fuel irradiation.

The conceptual details of these modifications, which have been incorporated into a code designated ORIGEN2, will be described in a later publication. Additionally, since the recoverable-energy-per-fission values for the various actinides are nearly constant for all reactor types, the values used in ORIGEN2 will be discussed generically in this same publication. The values of THERM, RES, and FAST that have been derived from XSDRNPM $^{2}$ neutron-energy-spectrum calculations are given in Table 4.1 . These values are not compatible with previous versions of ORIGEN since they are based on total flux instead of thermal flux. A relatively straightforward (but approximate) conversion process yields the THERM, RES, and FAST values given in Table 4.2 , which are compatible with previous versions of ORIGEN.

The variable actinide cross sections used in ORIGEN2 for the reactor models result from the CITATION calculations discussed in Sect. 3 and are given in Appendix $C$ for the PWR-U and PWR-PuPu fuels. ORIGEN2 has provisions for calculating and incorporating new values for those cross. sections listed in the tables in Appendix C before each irradiation step. The fission product yields are also adjusted for those actinides that have variable fission cross sections and are designated as fission product producers (e.g., ${ }^{235} \mathrm{U},{ }^{239} \mathrm{Pu}$, and ${ }^{241} \mathrm{Pu}$ ). 
Table 4.1. Values of THERM, RES, and FAST to be used with LWR total fluxes ${ }^{a}$

\begin{tabular}{|c|c|c|c|c|}
\hline Fuel type & THERM & RES & FAST & $\begin{array}{l}\text { Total flux } \\
\text { (neutrons } \mathrm{cm}^{-2} \mathrm{sec}^{-1} \text { ) }\end{array}$ \\
\hline PWR-U & 0.0748 & 0.0251 & 0.3113 & $3.25 \times 10^{14}$ \\
\hline \multicolumn{5}{|l|}{ PWR-Pu } \\
\hline PWR-PuU & 0.0698 & 0.0255 & 0.3129 & $3.18 \times 10^{14}$ \\
\hline PWR-PuPu & 0.0322 & 0.0235 & 0.3510 & $3.26 \times 10^{14}$ \\
\hline BWR-U & 0.0834 & 0.0256 & 0.2345 & $2.35 \times 10^{14}$ \\
\hline \multicolumn{5}{|l|}{$\mathrm{BWR}-\mathrm{Pu}$} \\
\hline BWR-PuU & 0.0739 & 0.0262 & 0.2370 & $2.55 \times 10^{14}$ \\
\hline $\mathrm{BWR}-\mathrm{PuPu}$ & 0.0505 & 0.0246 & 0.2563 & $2.08 \times 10^{14}$ \\
\hline
\end{tabular}

Table 4.2. Values of THERM, RES, and FAST to be used with t.WR thermal fluxes

\begin{tabular}{|c|c|c|c|c|c|c|}
\hline \multirow[b]{2}{*}{ Fue.1 type } & \multicolumn{2}{|c|}{ THERM } & \multicolumn{2}{|c|}{ RES } & \multicolumn{2}{|c|}{ FAST } \\
\hline & old & $\overline{\text { newa }}$ & old & $\overline{n e w^{a}}$ & $01 d$ & newa \\
\hline PWR-U & 0.632 & 0.701 & 0.333 & 0.304 & 2.000 & 2.010 \\
\hline \multicolumn{7}{|l|}{ PWR-Pu } \\
\hline PWR-PuU & 0.632 & 0.592 & 0.333 & 0.366 & 2.000 & 2.390 \\
\hline PWR-PuPu & 0.500 & 0.509 & 0.550 & 0.730 & 4.000 & 5.490 \\
\hline BWR-U & 0.632 & 0.676 & 0.333 & 0.307 & 2.000 & 1.314 \\
\hline \multicolumn{7}{|l|}{$\mathrm{BWR}-\mathrm{Pu}$} \\
\hline BWR-PuU & 0.632 & $\mathrm{~b}$ & 0.333 & 0.355 & 2.000 & 1.694 \\
\hline $\mathrm{BWR}-\mathrm{PuPu}$ & 0.500 & b & 0.550 & 0.487 & 4.000 & 2.599 \\
\hline
\end{tabular}




\subsection{Input Compositions and Masses}

There are three different composition-related aspects to be considered when specifying the LWR fuel-input composition:

1. the mass and composition of the fuel-assembly structural materials associated with a given amount of fuel,

2. the trace element concentrations in the oxide fuel pellets, and

3. the heavy-metal isotopic compusition of the fuel.

\subsubsection{Fuel-assembly structural material masses and compositions}

4.2.1.1 Composition. The seven structural materials used in the revised ORIGEN LWR models are Zircaloy-2, Zircaloy-4, Inconel 718 , Inconel X-750, stainless steel 302 , stainless steel 304 , and Nicrobraze 50. The assumed elemental composition of each of these materials is given in Table 4.3 .

A parameter of particular interest in Table 4.3 is the cobalt content of these structural materials. This is bccause naturally occurring ${ }^{59} \mathrm{Co}$ produces ${ }^{60} \mathrm{Co}$ which emits high-energy gamma rays that inhibit the detection of residual amounts of actinides in the structural materials after fuel dissolution. The cobalt is a contaminant in metals containing nickel and results from the use of nickel that has been previously alloyed with cobalt. By judiciously selecting the heats from which the metals containing nickel are taken, it appears to be possible to limit the cobalt contamination to $20.08 \mathrm{wt} \%$ for stainless steels. 7 
Table $\{.3$. Assumed elemenial compositions of LWR fuel-assembly siructural materials

\begin{tabular}{|c|c|c|c|c|c|c|c|c|}
\hline \multirow[b]{2}{*}{ Element } & \multirow[b]{2}{*}{$\begin{array}{l}\text { Atomic } \\
\text { number }\end{array}$} & \multicolumn{7}{|c|}{ Structural material composition, grans per tonre of metal } \\
\hline & & ZLrcaloy-2 & Zircaloy-4 & Inconel $-7-8$ & Inconel $\mathrm{X}-750$ & $\begin{array}{c}\text { Stainless steeI } \\
302\end{array}$ & $\begin{array}{c}\text { Stalnless steel } \\
304\end{array}$ & Nicrobraze 50 \\
\hline H & 1 & 13 & 13 & 0 & 0 & 0 & 0 & 0 \\
\hline B & 5 & 0.33 & 0.33 & 0 & . $\quad 0$ & 0 & 0 & 50 \\
\hline c & 6 & 120 & 120 & 400 & 399 & 1,500 & 800 & 100 \\
\hline $\mathrm{N}$ & 7 & 80 & 80 & 1,300 & 1,300 & 1,300 & 1,300 & 66 \\
\hline 0 & 8 & 950 & 950 & 0 & 0 & 0 & 0 & 43 \\
\hline $\mathrm{Al}$ & 13 & 24 & 24 & 5,992 & 7,982 & 0 & 0 & 100 \\
\hline Si & 14 & 0 & 0 & 1,997 & 2,993 & 10,000 & 10,000 & 511 \\
\hline $\mathbf{P}$ & 15 & 0 & 0 & 0 & 0 & 450 & 450 & 103,244 \\
\hline $\mathbf{s}$ & 16 & 35 & 35 & 70 & 70 & 300 & 300 & 100 \\
\hline $\mathrm{Ti}$ & 22 & 20 & 20 & 7,990 & 24,943 & 0 & 0 & 100 \\
\hline $\mathrm{v}$ & 23 & 20 & 20 & -0 & 0 & 0 & 0 & 0 \\
\hline $\mathrm{Cr}$ & 24 & 1,000 & $I, 250$ & 189,753 & 149,660 & 180,000 & 190,000 & 149,709 \\
\hline $\mathrm{Mn}^{\mathrm{a}}$ & 25 & 20 & 20 & 1,997 & 6,984 & $2 C, 000$ & 20,000 & 100 \\
\hline $\mathrm{Fe}$ & 26 & 1,500 & 2,250 & 179,766 & 67,846 & $69 i, 740$ & 688,440 & 471 \\
\hline $\mathrm{Co}^{\mathrm{a}}$ & 27 & 10 & 10 & 4,694 & 6,485 & 800 & 800 & 381 \\
\hline $\mathrm{N} 1$ & 28 & 500 & 20 & 519,625 & 721,861 & 85,200 & 89,200 & 744,438 \\
\hline $\mathrm{Cu}$ & 29 & 20 & 20 & 999 & 499 & 0 & 0 & 0 \\
\hline $2 r^{a}$ & 40 & 379,630 & 979,110 & 0 & 0 & 0 & 0 & 100 \\
\hline $\mathrm{Nb}$ & 41 & 0 & 0 & 55,458 . & 8,980 & 0 & 0 & 0 \\
\hline Mo & 42 & 0 & 0 & 29,961 & 0 & 0 & 0 & 0 \\
\hline Cd & 48 & 0.25 & 0.25 & 0 & 0 & 0 & 0 & 0 \\
\hline Sn & 50 & 16,000 & 16,000 & 0 & 0 & 0 & 0 & 0 \\
\hline Hf & 72 & 78 & 78 & 0 & 0 & 0 & 0 & 0 \\
\hline w & 74 & 20 & 20 & 0 & 0 & 0 & 0 & 100 \\
\hline $\mathrm{U}$ & 92 & 0.2 & 0.2 & 0 & 0 & 0 & 0 & 0 \\
\hline $\begin{array}{l}\text { Densi=y, } \\
\text { grams } / \mathrm{cm}^{3}\end{array}$ & -- & 6.56 & 6.56 & 8.19 & 8.30 & 8.02 & 8.02 & -- \\
\hline References & & 3,4 & 3,4 & $4-7$ & $4-7$ & $4,6-8$ & $4,6-8$ & 9 \\
\hline
\end{tabular}

aalue used in ORIGEN sholld be less than this (actual: value =f the materials are not in the active fiel zone; see Sect. $3 . j$ and Table 3.7 for Jetails. 
4.2.1.2 Structural material mass distribution. The PWR and BWR fuel-assembly structural material distributions recommended for use in reactor depletion calculations are given in Table 4.4. The various materials have been grouped into three categories (i.e., fuel zone, fuel-gas plenum zone, and end fitting zone) according to their proximity to the active fuel region. These categories correspond to those for which effective neutron fluxes were determined using axial neutron transport calculations (see Sect. 3.5). The elemental compositions of all materials listed in Table 4.4 are given in Table 4.3. It should be noted that the BWR fuel channel, which encloses the square array of fuel elements to prevent cross-flow between adjacent assemblies, is assumed to be used once before being discarded, even though it can be used more than once. ${ }^{10}$.

4.2.1.3 Fuel-assembly dimensions. The physical parameters of spent PWR and BWR fuel assemblies are given in Table 4.5 , even though they are not directly related to ORIGEN calculations. These parameters are presented because of the current interest in this information as it relates to the possible storage and disposal of unreprocessed spent fuel.

\subsubsection{Nonactinide element composition of LWR oxide fuels}

The nonactinide elements present. in fresh LWR fuels are comprised of a large number of trace elements $(<100 \mathrm{ppm})$ plus the oxygen present in the actinide oxide fuel material. A typical set of nonactinide element concentrations in fresh LWR oxide fuel is given in Table 4.6. The values in Table 4.6 generally reflect actual measured concentrations, instead of the maximum allowable concentrations given in purity specifications. If the concentration of a particular element has been determined to be less than a particular value, then that value is used in Table 4.6. 
Table 4.4. Assumed fuel-asiembly structural material mass distribution

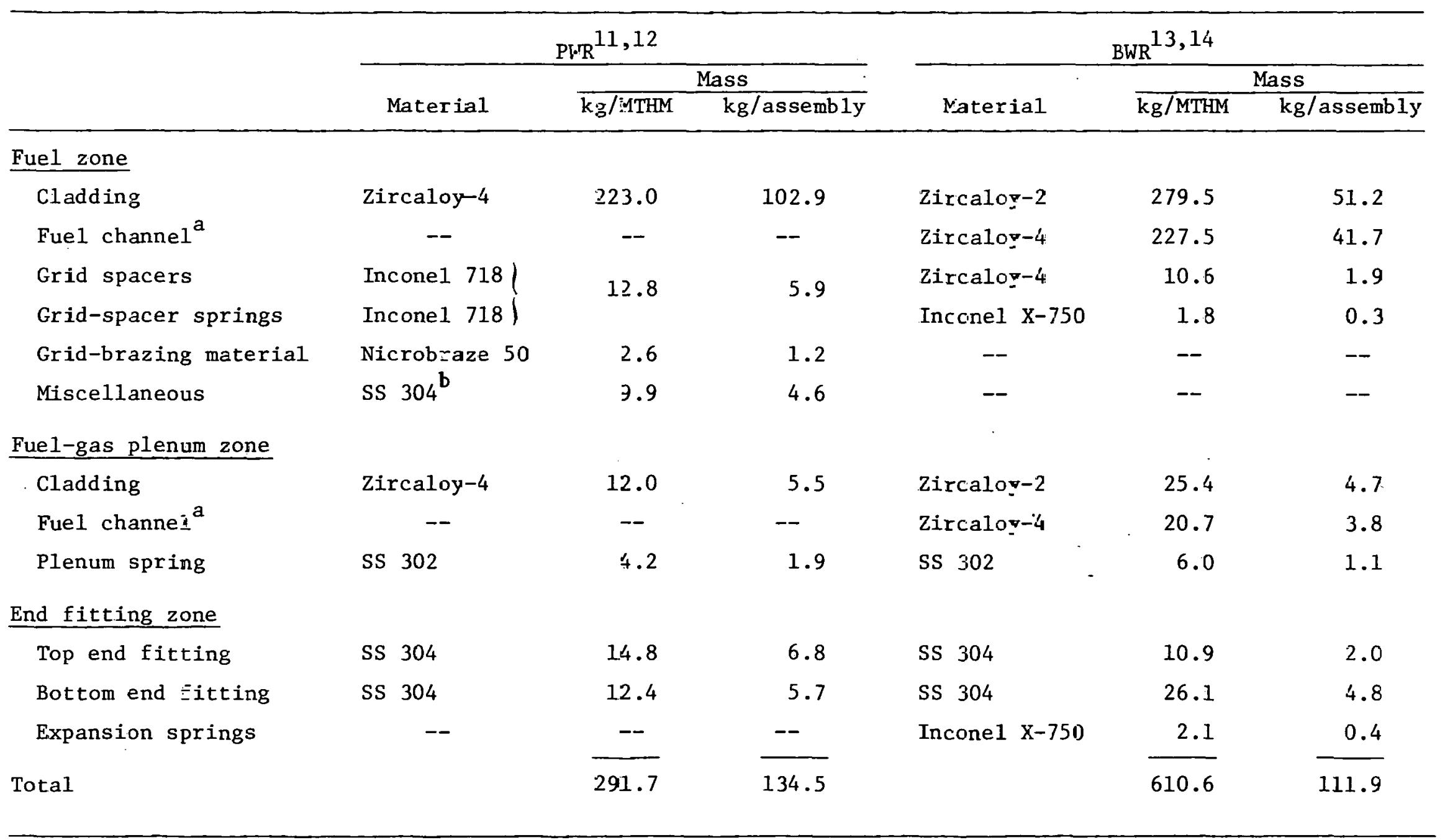

${ }^{a}$ Assumed to be discarded after one cycle (ref. 10).

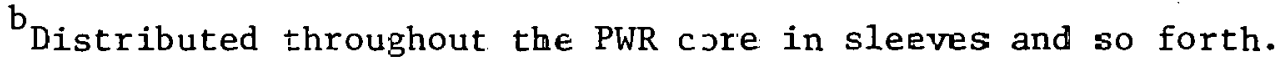


Table 4.5. Physical characteristics of LWR fuel assemblies

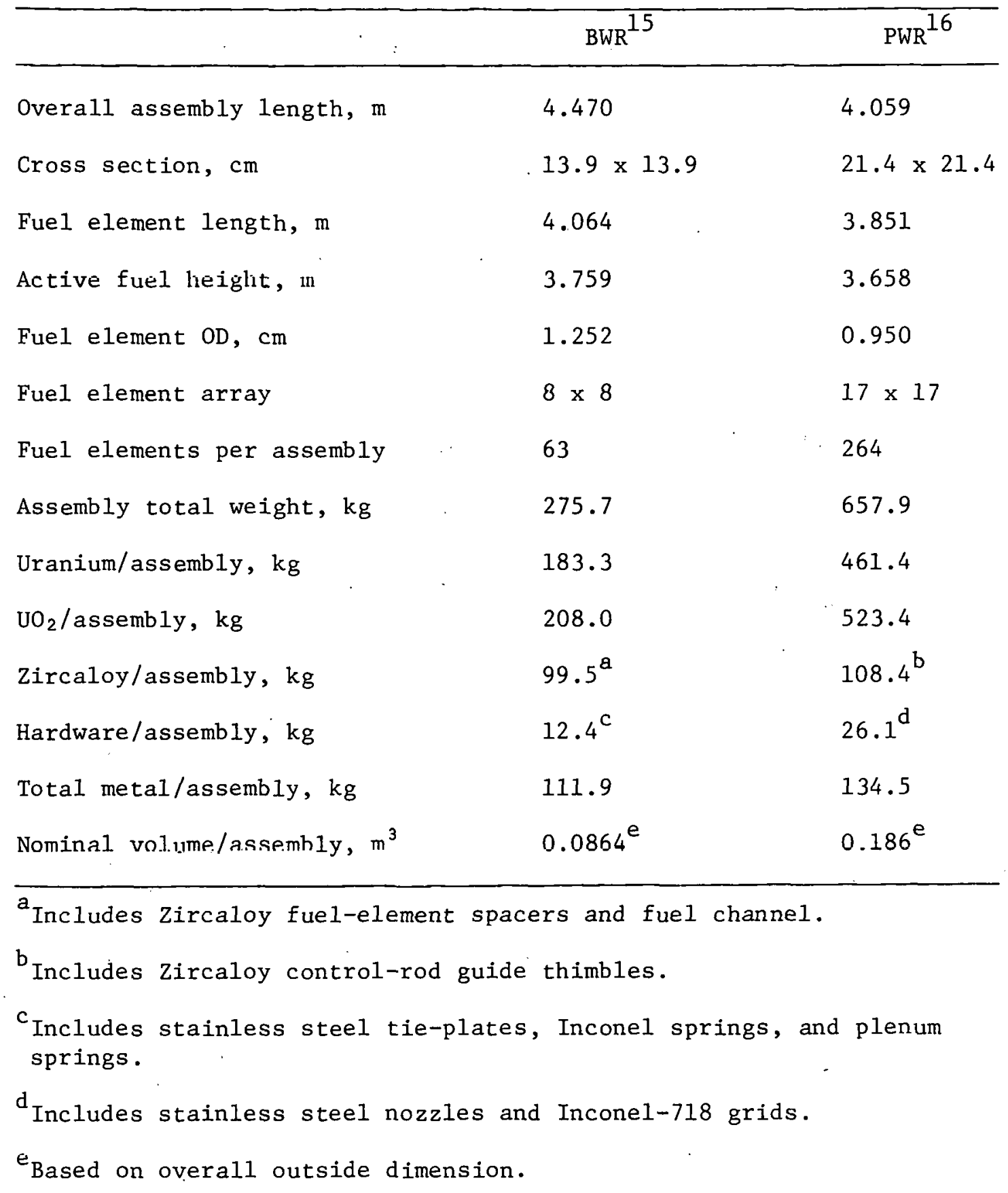


Table 4.6. Assumed nonactinide composition of LWR oxide fuels

\begin{tabular}{|c|c|c|c|c|c|c|c|}
\hline Element & $\begin{array}{l}\text { Atomic } \\
\text { number }\end{array}$ & $\begin{array}{l}\text { Concentration } \\
(\mathrm{ppm})^{\mathrm{a}}\end{array}$ & Reference & Element & $\begin{array}{l}\text { Atomic } \\
\text { number }\end{array}$ & $\begin{array}{l}\text { Concentration } \\
(\mathrm{ppm})^{\mathrm{a}}\end{array}$ & Reference \\
\hline $\mathrm{Li}$ & 3 & 1.0 & 17 & $\mathrm{Mn}$ & 25 & 1.7 & 18 \\
\hline B & 5 & 1.0 & 18 & $\mathrm{Fe}$ & 26 & 18.0 & 18 \\
\hline $\mathrm{C}$ & 6 & 89.4 & 18 & Co & 27 & 1.0 & 18 \\
\hline $\mathrm{N}$ & 7 & 25.0 & 4 & $\mathrm{Ni}$ & 28 & 24.0 & 18 \\
\hline 0 & 8 & 134,454 & $b$ & $\mathrm{Cu}$ & 29 & 1.0 & 18 \\
\hline F & 9 & 10.7 & 18 & $\mathrm{Zn}$ & 30 & 40.3 & 18 \\
\hline $\mathrm{Na}$ & 11 & 15.0 & 18 & Mo & 42 & 10.0 & 18 \\
\hline $\mathrm{Mg}$ & 12 & 2.0 & 18 & $\mathrm{Ag}$ & 47 & 0.1 & 18 \\
\hline $\mathrm{Al}$ & 13 & 16.7 & 18 & $\mathrm{Cd}$ & 48 & 25.0 & 18 \\
\hline Si & 14 & 12.1 & 18 & In & 49 & 2.0 & 18 \\
\hline $\mathrm{P}$ & 15 & 35.0 & 19 & Sn & 50 & 4.0 & 18 \\
\hline $\mathrm{C} 1$ & 17 & 5.3 & 18 & $\mathrm{Gd}$ & 64 & $2.5^{c}$ & 18 \\
\hline $\mathrm{Ca}$ & 20 & 2.0 & 18 & $W$ & 74 & 2.0 & 18 \\
\hline $\mathrm{T} \mathbf{i}$ & 22 & 1.0 & 20 & $\mathrm{~Pb}$ & 82 & 1.0 & 18 \\
\hline $\mathrm{V}$ & 23 & 3.0 & 18 & $\mathrm{Bi}$ & 83 & 0.4 & 20 \\
\hline $\mathrm{Cr}$ & 24 & 4.0 & 18 & & & & \\
\hline
\end{tabular}

Parts of element per million parts sf heavy netal.

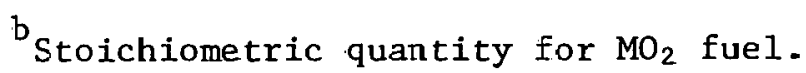

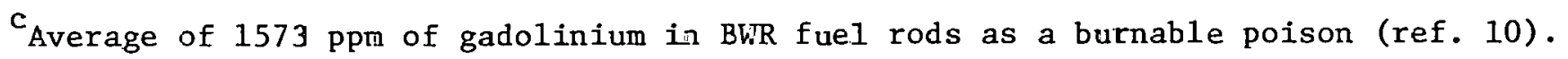


The 2.5-ppm gadolinium concentration given in Table 4.6 is only appropriate for. PWRs. The use of gadolinium as a burnable poison mixed with the BWR oxide fuel results in this value being increased to 1573 ppm on the average. 10

\subsubsection{Initial heavy-metal composition in LWR oxide fuels}

The average, initial heavy-metal (i.e., actinide) composition of one metric ton of fuel for the four LWRs is given in Table 4.7. The average fuel composition for each of the plutonium recycle reactors (e.g., the PWR-Pu) is comprised of two parts: a uranium-enriched part (e.g., PWR-PuU) that accounts for $270 \%$ of the fresh fuel and a plutoniumenriched part (e.g., PWR-PuPu) that accounts for $\sim 30 \%$ of the fresh fuel. The plutonium compositions in Table 4.7 are typical of those expected at the beginning of the second plutonium recycle and include the plutonium produced during the first plutonium recycle in both the uraniumand plutonium-enriched fuel. Thus, the model represents self-generated plutonium recycle (see Sect. 3.3), but not steady-state plutonium recycle, which would require that the amount of plutonium discharged after recycle $\mathrm{N}$, less processing losses, be equal to the amount charged to the plutoniumenriched fuel in recycle $\mathrm{N}+1$.

\subsection{ORIGEN Depletion Calculations}

This section describes and compares the results of ORIGEN depletion calculations for the four reactor (e.g., PWR-U, PWR-Pu, BWR-U, and BWR-Pu) fuel-cycle combinations considered in the previously described CITATION ${ }^{21}$ calculations (Sect. 3.4). These ORIGEN calculations require (1) the implementation of the modifications described in Sect. 4.1, (2) cross 
Tatle 4.7. Assumed initial composition of one average metri= con of heavy metal in LWRs

\begin{tabular}{|c|c|c|c|c|c|c|c|c|}
\hline & \multirow[b]{2}{*}{ PWR-E } & \multicolumn{3}{|c|}{ PWE-Pu } & \multirow[b]{2}{*}{$B N R-U$} & \multicolumn{3}{|c|}{ BWR-Pu } \\
\hline & & $\overline{\mathrm{PWR}-\mathrm{PuU}}$ & PWR-FuPu & Total & & $\overline{\text { BNR-PuU }}$ & BWR-PuPu & Total \\
\hline${ }^{234} \mathrm{U}, \mathrm{g}$ & 290 & 203 & 16 & 219 & 247 & 173 & 16 & 189 \\
\hline${ }^{235} \mathrm{U}, \mathrm{g}$ & 32,300 & 22,400 & $2, \mathbb{C}: 38$ & 24,438 & 27,500 & 19,250 & 2,349 & 21,301 \\
\hline${ }^{238} \mathrm{U}, \mathrm{g}$ & $967, \pi 10$ & 677,397 & $284, \equiv 17$ & 961,714 & 972,253 & $6: 30,577$ & 286,159 & 966,717 \\
\hline Total $\mathrm{U}, \mathrm{g}$ & $1,000, \approx 00$ & 700,000 & $286, \cong 71$ & 986,371 & $1,001,000$ & $71) 0,000$ & 288,224 & 988,207 \\
\hline${ }^{238} \mathrm{Pu}, \mathrm{g}$ & 0 & 0 & $\Xi 04$ & 304 & 0 & 0 & 311 & 312 \\
\hline${ }^{239} \mathrm{Pu}, \mathrm{g}$ & 0 & 0 & 6,722 & 6,722 & 0 & 0 & 5,723 & 5,730 \\
\hline${ }^{240} \mathrm{Pu}, \mathrm{g}$ & 0 & 0 & 3,472 & 3,472 & 0 & 0 & 3,229 & 3,240 \\
\hline${ }^{241} \mathrm{Pu}, \mathrm{g}$ & 0 & 0 & 1,595 & 1,995 & 0 & 0 & 1,564 & 1,563 \\
\hline${ }^{242} \mathrm{Pu}, \mathrm{g}$ & 0 & 0 & 1,136 & 1,136 & 0 & 0 & 949 & 943 \\
\hline Total Pu, g & 0 & 0 & 13,629 & 13,629 & 0 & 0 & 11,776 & 11,793 \\
\hline Total heavy metal, g & $1,000, \approx 00$ & 700,000 & 300,600 & $1,000,000$ & $1,031,000$ & 700,000 & 300,000 & $1,000,000$ \\
\hline
\end{tabular}


sections resulting from the reactor physics calculations described in Sect. 3, and (3) the input masses and compositions described in Sect. 4.2. A brief comparison of the PWR-U and BWR-U discharged-fuel composition predicted by CITATION and ORIGEN is given in Sect. 4.3.1. Section 4.3.2 contains comparisons of the discharged-fuel composition predicted by ORIGEN for all four reactor/fuel cycle combinations with available literature values. Section 4.3 .3 contains a summary description of the ORIGEN U-Pu cycle LWR models.

\subsubsection{Comparison of ORIGEN and CITATION depletion calculations}

Actinide depletion calculations were performed for the PWR-U and BWR-U reactors with both the ORIGEN and CITATION computer codes to verify the accuracy of ORIGEN (or CITATION) as a depletion module and to test the effectiveness of the ORIGEN modifications described in Sect. 4.1. A summary of the results of these calculations is given in Table 4.8.

In general, the discharged compositions of the spent fuels predicted by the two depletion codes agree very well, with most differences being $<1 \%$. Any differences $>1 \%$ can be attributed to the exclusion of certain decay chains from the CITATION calculations in order to eliminate the presence of feedback loops that cannot be handled by CITATION. The decay loops that were eliminated are the alpha-decay (100\% of all decay events) of ${ }^{242} \mathrm{Cm}$ to ${ }^{238} \mathrm{Pu}$ and the electron-capture-decay (18\% of all decay events) of ${ }^{242} \mathrm{Am}$ to ${ }^{242} \mathrm{Pu}$. If the ${ }^{242} \mathrm{Cm}$ alpha-decays were included in CITATION, the effect would be an increase in the amounts of ${ }^{238} \mathrm{Pu}$ and total plutonium at discharge. The inclusion of the ${ }^{242} \mathrm{Am}$ electron-capturedecays would decrease the amount of ${ }^{242} \mathrm{Cm}$ present at discharge somewhat and increase the amounts of ${ }^{242} \mathrm{Pu},{ }^{243} \mathrm{Am}$, and ${ }^{244} \mathrm{Cm}$ present at discharge. 
Table 4.8. Comparison of CITATION and ORIGEN depletion calculations at discharge for uranlum-enriched LWRs

\begin{tabular}{|c|c|c|c|c|c|c|}
\hline \multirow[b]{2}{*}{ Nuclide } & \multicolumn{3}{|c|}{ PWR-U ${ }^{a}$} & \multicolumn{3}{|c|}{$B W R-U^{d}$} \\
\hline & $\begin{array}{l}\text { CITATION } \\
\text { (g/MTIHM) }\end{array}$ & $\begin{array}{l}\text { ORIGEN } \\
\text { (g/MTIHM) }\end{array}$ & $\begin{array}{c}\text { Difference } \\
(\%)\end{array}$ & $\begin{array}{l}\text { CITATION }^{b} \\
\text { (g/MTIHM) }\end{array}$ & $\begin{array}{l}\text { ORIGEN } \\
\text { (g/MTIHM) }\end{array}$ & $\begin{array}{c}\text { Difference } \\
(\%)\end{array}$ \\
\hline${ }^{234} \mathrm{U}$ & 179 & 180 & $-0.9^{\mathrm{e}}$ & 157 & 157 & $0^{\mathrm{e}}$ \\
\hline${ }^{235} \mathrm{U}$ & 8,068 & 7,936 & $+0.6^{e}$ & 7,567 & 7,522 & $+0.2^{\mathrm{e}}$ \\
\hline${ }^{236} \mathrm{U}$ & 3,948 & 3,963 & +0.4 & 3,307 & 3,314 & +0.2 \\
\hline $238 \mathrm{U}$ & 944,100 & 944,100 & $0^{\mathrm{e}}$ & 951,700 & 951,700 & $0^{e}$ \\
\hline${ }^{2}{ }^{7} \mathrm{~Np}$ & 4.34 & 441 & -1.6 & 334 & 338 & +1.2 \\
\hline $23^{8} \mathrm{Pu}$ & $112^{\mathrm{f}}$ & 127 & $+13.4^{6}$ & $80.6^{\mathrm{f}}$ & 93.2. & $+15.6^{8}$ \\
\hline $239 \mathrm{Pu}$ & 4,972 & 5,033 & +1.2 & 4,787 & 4,831 & +0.9 \\
\hline $20^{\circ} \mathrm{Pu}$ & 2,293 & 2,318 & +1.0 & 2,086 & $2,09 y$ & +0.6 \\
\hline${ }^{241} \mathrm{Pu}$ & 1,205 & 1,223 & +1.5 & 1,086 & 1,094 & +0.7 \\
\hline $242 \mathrm{Pu}$ & $444^{h}$ & 461 & $-3.8^{i}$ & $370^{h}$ & 379 & $+2.4^{1}$ \\
\hline Total Pu & $9,029^{f, h}$ & 9,162 & $+1.5^{g, i}$ & $8,410^{f, h}$ & 8,496 & $+1.0^{8, i}$ \\
\hline $241 \mathrm{Am}$ & 32.4 & 31.7 & -2.2 & 36.6 & 36.1 & -1.4 \\
\hline $243 \mathrm{Am}$ & $81.4^{h}$ & 85.9 & $+5.5^{i}$ & $61.6^{\mathrm{h}}$ & 63.7 & $+3.4^{i}$ \\
\hline${ }^{242} \mathrm{Cm}$ & $13.2^{\mathrm{J}}$. & 11.4 & $-13.6^{6}$ & $12.0^{\mathrm{J}}$ & 10.2 & $-15.0^{5}$ \\
\hline $24+4 \mathrm{Cm}$ & $.17 .8^{\mathrm{h}}$ & 19.0 & $16.7^{i}$ & $12: 3^{h}$ & 12.8 & $+4.1^{i}$ \\
\hline
\end{tabular}

Initial composition: $290 \mathrm{~g}^{234} \mathrm{U} ; 32,000 \mathrm{~g}^{235} \mathrm{U} ; 967,710 \mathrm{~g}^{238} \mathrm{U}$.

$\mathrm{b}_{\text {Ref. } 21 \text {. }}$

$c_{\%}$ difference $=100$ (ORIGEN-CITATION) $/$ ORIGEN .

dinitial composition: $247 \mathrm{~g}^{234} \mathrm{U} ; 27,500 \mathrm{~g}^{235} \mathrm{U} ; 972,253 \mathrm{~g}^{238} \mathrm{U}$.

$e_{\%}$ difference based on depletion from initial amount.

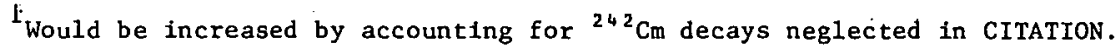

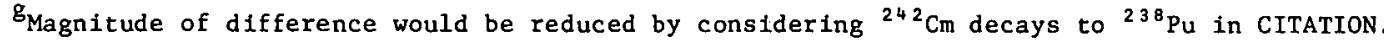

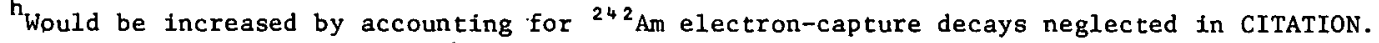

${ }^{1}$ Magnitude of difference would be reduced by considering ${ }^{2+2}$ Am electron-capture decays in CITATION.

$j_{\text {Would be decreased by accounting for }}{ }^{242} \mathrm{Am}$ electron-capture decays neglected in CITATION. 
In all cases, these changes serve to decrease the magnitude of the difference between the CITATION and ORIGEN depletion calculations.

\subsubsection{Comparison of ORIGEN and literature depletion calculations}

Since the reactor models used in the CITATION calculations were relatively simple, there is no assurance that the results of the ORIGEN calculations are correct, even if they are in good agreement with the CITATION calculations. Thus, it is necessary to compare the ORIGEN results with similar calculations from an exogenous source. Unfortunately, there is no single "reference" set of calculations which can serve as a basis for comparison, and large-scale dissolution and analysis of spent fuels from modern LWRs have not been performed yet. The net result is that the only exogenous basis of comparison is the multitude of spent fuel compositions that have been published in the literature. The appraoch taken in the following discussion is to compare the results of ORIGEN depletion calculations with the published discharged-fuel compositions. This procedure generally necessitates multiple ORIGEN runs for a given reactor since the different sources assumed different burnups and/or initial enrichments. It should be noted that the appearance of a spent fuel composition from the literature does not necessarily imply that it is more accurate than the ORIGEN calculation, since the methods and assumptions used in many of the literature calculations are unknown.

4.3.2.1 PWR-U fuel. The comparison of the PWR-U spent fuel compositions calculated by ORIGEN with those given in the literature is shown in Table 4.9. Each column entitled "ORIGEN" is followed by one or more columns which give the comparable literature values. As is evident by inspection, the agreement between ORIGEN and the 1iterature values for 
Table 4.5. Comparison of ORIGE: PtR-U fuel depletion calculaticns with 11terature ralues

\begin{tabular}{|c|c|c|c|c|c|c|c|c|c|c|c|}
\hline \multirow[b]{2}{*}{ Nuclide } & \multicolumn{11}{|c|}{ D1scharge PWR-U fuel couposition $\cdot g / \mathrm{MT}$ DWM) } \\
\hline & ORICEN & $\operatorname{Ref} .22$ & Fef. 23 & Ref. $24^{\mathrm{a}}$ & Ref. 25 & Ref. 26 & Réf. $27^{8}$ & ORIGEN & Ref. 28 & JRICEN & Ref. 29 \\
\hline${ }^{234} \mathrm{U}$ & $\left(\mathrm{D} \stackrel{180}{=110)^{\mathrm{b}}}\right.$ & $\begin{array}{c}158 \\
(D=132)\end{array}$ & $\overline{(-)}$ & $(D=151 ;)$ & $\overline{(-)}$ & $\begin{array}{l}- \\
(-)\end{array}$ & $\begin{array}{c}116 \\
(\mathrm{D}=174)\end{array}$ & $(\rightarrow)$ & $(-)$ & $(-)$ & $\cdot(-)$ \\
\hline $235_{U}$ & $(\mathrm{D}=24.064)^{\mathrm{b}}$ & $\begin{array}{c}8151 \\
(D=23,849)\end{array}$ & $\begin{array}{c}8500 \\
([-=23,500)\end{array}$ & $\dot{(-)}$ & $\begin{array}{c}8006 \\
(D=23,964)\end{array}$ & $\begin{array}{c}7924 \\
(D=24,076)\end{array}$ & $\begin{array}{l}7460 \\
(D-24,440)\end{array}$ & 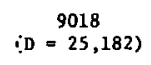 & $\begin{array}{c}9370 \\
(D=24,830)\end{array}$ & $\begin{array}{c}8084 \\
(D=22,016)\end{array}$ & $\begin{array}{c}8148 \\
(D=21,952)\end{array}$ \\
\hline $236 \mathrm{u}$ & 3963 & 4002 & 4005 & 3933 & $4500^{\mathrm{C}}$ & 4033 & .820 & - & - & 3653 & $35 \varepsilon 8$ \\
\hline${ }^{230_{U}}$ & $\left(D^{944,100}=23,610\right)^{b}$ & $\begin{array}{c}943,430 \\
(D=2 C, 280)\end{array}$ & $\begin{array}{c}542,788 \\
([-25,212)\end{array}$ & $\dot{(-)}$ & $\left(D^{933,585^{d}}=34,15\right)^{d}$ & $\begin{array}{c}943,742 \\
(D-23,967)\end{array}$ & $\begin{array}{c}9: 4,000 \\
(D=23,810)\end{array}$ & $(-)$ & $(-)$ & $\begin{array}{c}947,300 \\
(D=22,310)\end{array}$ & $\begin{array}{c}946,764 \\
(D=24,846)\end{array}$ \\
\hline${ }^{237} \mathrm{~Np}$ & 441 & 449 & - & $4 \times 3$ & - & - & 482 & - & - & - & - \\
\hline${ }^{23 \mathrm{P}_{\mathrm{Pu}}}$ & $\frac{127}{(1.4 z)^{\mathrm{e}}}$ & $\begin{array}{l}13 \mathrm{i} \\
(1.2 x)\end{array}$ & $(-)$ & $\begin{array}{l}1.15 \\
(1.48)\end{array}$ & $\begin{array}{c}178 \\
(1.9 z)\end{array}$ & $(-)$ & $\begin{array}{l}167 \\
: 1.88)\end{array}$ & $\begin{array}{c}120 \\
(1.38)\end{array}$ & - & $\begin{array}{c}107 \\
(1.2 z)\end{array}$ & $\begin{array}{l}- \\
(-)\end{array}$ \\
\hline${ }^{239} \mathrm{Pu}$ & $\underset{(54.98)^{5033}}{5}$ & $\begin{array}{l}5313 \\
(56.2 \pi)\end{array}$ & $\begin{array}{c}5570 \\
57.32)\end{array}$ & $\begin{array}{l}5490 \\
(56.97)\end{array}$ & $\begin{array}{c}5250 \\
(57.0 z)\end{array}$ & $\begin{array}{c}5036 \\
(54.8 x)\end{array}$ & $\begin{array}{l}\$ 300 \\
(88.4 x)\end{array}$ & $\begin{array}{c}5007 \\
(55.8 x)\end{array}$ & $\begin{array}{c}5370 \\
(57.6 x)\end{array}$ & $\begin{array}{c}5008 \\
(56.12)\end{array}$ & $\begin{array}{r}5321 \\
(58.17)\end{array}$ \\
\hline${ }^{240} \mathrm{Pu}$ & $\frac{2318}{(25.32)^{\mathrm{e}}}$ & $\begin{array}{l}2309 \\
(24 .<z)\end{array}$ & $\begin{array}{r}2238 \\
023.02)\end{array}$ & $\begin{array}{l}23: 2 \\
(24.1 \pi)\end{array}$ & $\begin{array}{c}2180 \\
(23.7 z)\end{array}$ & $\begin{array}{c}2219 \\
(24.18)\end{array}$ & $\begin{array}{l}: 200 \\
(: 4.2 x)\end{array}$ & $\begin{array}{r}2263 \\
(25.2 x)\end{array}$ & $\begin{array}{r}222.3 \\
(23.8 z)\end{array}$ & $\begin{array}{r}2219 \\
.(24.92)\end{array}$ & $\begin{array}{c}2098 \\
(22.92:\end{array}$ \\
\hline${ }^{241} \mathrm{Pu}$ & $(12.38)^{1223} \mathrm{e}^{\mathrm{e}}$ & $\begin{array}{l}1252 \\
(13.38)\end{array}$ & $\begin{array}{c}1370 \\
014.12)\end{array}$ & $\begin{array}{l}-22.5 \\
(12.98)\end{array}$ & $\begin{array}{c}1150 \\
(12.5 z)\end{array}$ & $\begin{array}{c}1243 \\
(13.52)\end{array}$ & $(.044)$ & $\begin{array}{c}1171 \\
(13.08)\end{array}$ & $\begin{array}{c}1310 \\
(14.0 .8)\end{array}$ & $\begin{array}{c}1168 \\
(\dot{3} 3.12)\end{array}$ & $\begin{array}{l}1277 \\
(14.08:\end{array}$ \\
\hline${ }^{242} \mathrm{Pu}$ & $(5.02)^{9}$ & $\begin{array}{c}446 \\
(4.2 z)\end{array}$ & $\begin{array}{c}542 \\
(5.65)\end{array}$ & $\begin{array}{l}4: 51 \\
(4.7 \pi)\end{array}$ & $\begin{array}{r}452 \\
(4.98)\end{array}$ & $\begin{array}{c}540 \\
(5.92)\end{array}$ & $\begin{array}{l}372 \\
-4.12)\end{array}$ & $\begin{array}{c}418 \\
(4.78)\end{array}$ & $\begin{array}{c}430 \\
(4.6 x)\end{array}$ & $\begin{array}{r}419 \\
4.780\end{array}$ & $\begin{array}{l}456 \\
\text { (5.0x: }\end{array}$ \\
\hline Fissile Pu & $\begin{array}{c}6256 \\
(68.3 x)\end{array}$ & $\begin{array}{l}6565 \\
(69.57)\end{array}$ & $\begin{array}{c}6540 \\
.71 .55)\end{array}$ & $\begin{array}{l}6735 \\
(69.8 \pi)\end{array}$ & $\begin{array}{c}6400 \\
(69.52)\end{array}$ & $\begin{array}{c}6279 \\
(69.5 x)\end{array}$ & $\begin{array}{l}-344 \\
(09.9 x)\end{array}$ & $\begin{array}{c}6178 \\
(68.82)\end{array}$ & $\begin{array}{c}6680 \\
(71.67)\end{array}$ & $\begin{array}{c}6176 \\
(69.28)\end{array}$ & $\begin{array}{r}6598 \\
(72.12)\end{array}$ \\
\hline Total $\mathrm{Pu}$ & 9162 & 945: & $9 \pi 12$ & $96+3$ & 9210 & 9038 & -080 & 8978 & 9330 & 8921 & 9151 \\
\hline${ }^{201} \mathrm{Am}$ & 31.7 & 44.2 & - & 1.98 & - & - & -0.8 & 30.6 & - & - & - \\
\hline${ }^{243}{ }_{\mathrm{AmI}}$ & 85.9 & 88.0 & - & 39 & - & - & 102 & 74.0 & - & - & - \\
\hline${ }^{242} \mathrm{~cm}$ & 11.4 & 17.0 & - & 5.0 & - & - & 5.1 & 10.4 & - & - & - \\
\hline${ }^{244} \mathrm{~cm}$ & 19.0 & 24.3 & - & 23.8 & - & - & $=0.2$ & 15.5 & - & - & - \\
\hline $\begin{array}{l}\text { Initial en- } \\
\text { richment, } \\
\text { wt } z 23 \mathrm{U}\end{array}$ & 3.210 & 3.20 & 3.20 & $\stackrel{?}{?}$ & 3.20 & 3.20 & .3 .19 & 3.42 & 3.42 & 3.01 & 3.01 \\
\hline $\begin{array}{l}\text { Burnup, } \\
\text { Mud }(t) / \text { tone } \\
\text { heavy metal }\end{array}$ & e $\quad 33,030$ & 33,000 & 32,854 & $?$ & 33,000 & 33,100 & 33,000 & 33,000 & 33,000 & 30,390 & 30,390 \\
\hline
\end{tabular}

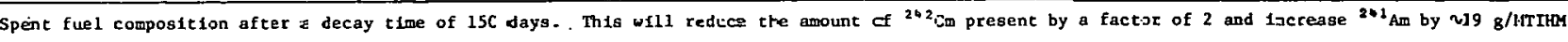

Indicates depletion of 1sotope in g/tTriHy.

${ }^{c}$ Initlal composition contalned $600 \mathrm{~g}$ of ${ }^{236} \mathrm{U} / \mathrm{MTIF}$.

dProbable typographical error; numbers should be $\$ 43,585$ and $D=24,125$.

eisotopic composition of plutarium as a weight pexcentage. 
the PWR-U is generally quite good, even for the americium and curium isotopes. It should be noted that two of the cases assume decay times of 150 days, thus affecting the amounts of ${ }^{241} \mathrm{Am}$ and ${ }^{242} \mathrm{Cm}$ present. These cases have been designated with a footnote.

A second comparison of the PWR-U discharged-fuel composition is given in Table 4.10, with the basis for comparison being the dischargedfuel composition predicted by the original ORIGEN cross section libraries. The agreement for ${ }^{235,238} \mathrm{U}$ and the principal plutonium isotopes is reasonably good; however, the new cross sections result in significant changes in the amounts of ${ }^{238} \mathrm{Pu},{ }^{243} \mathrm{Am}$, and ${ }^{244} \mathrm{Cm}$ present at discharge.

4.3.2.2 BWR-U fuel. The comparison of the ORIGEN and literature spent fuel compositions for BWR-U fuels is given in Table 4.11. In general, the agreement is quite good, although significant differences do exist between refs. 25,30 , and 31 . It should be noted however that this agreement was obtained at the expense of having to adjust the moderator density somewhat arbitrarily, as described in Sect. 3.2.3.

4.3.2.3 PWR-PuU fuel. The comparison of the ORIGEN and the single literature spent fuel compositions for the uranium-enriched fuel in a self-generated pluconlum recycle reactor is given in l'able 4.12. The agreement between ORIGEN and the literature values is quite good in this case, although it is difficult to generalize here because of the limited comparison basis.

4.3.2.4 PWR-PuPu fuel. The ORIGEN and 1iterature spent fuel composition predictions for the mixed-oxide fuel in a self-generated plutonium recycle reactor are given in Table 4.13. The different assumptions used in the literature calculations make the comparison of 
Table 4.10. Comparison of PWR-U discharged-fuel composition predicted by the old and new ORIGENs

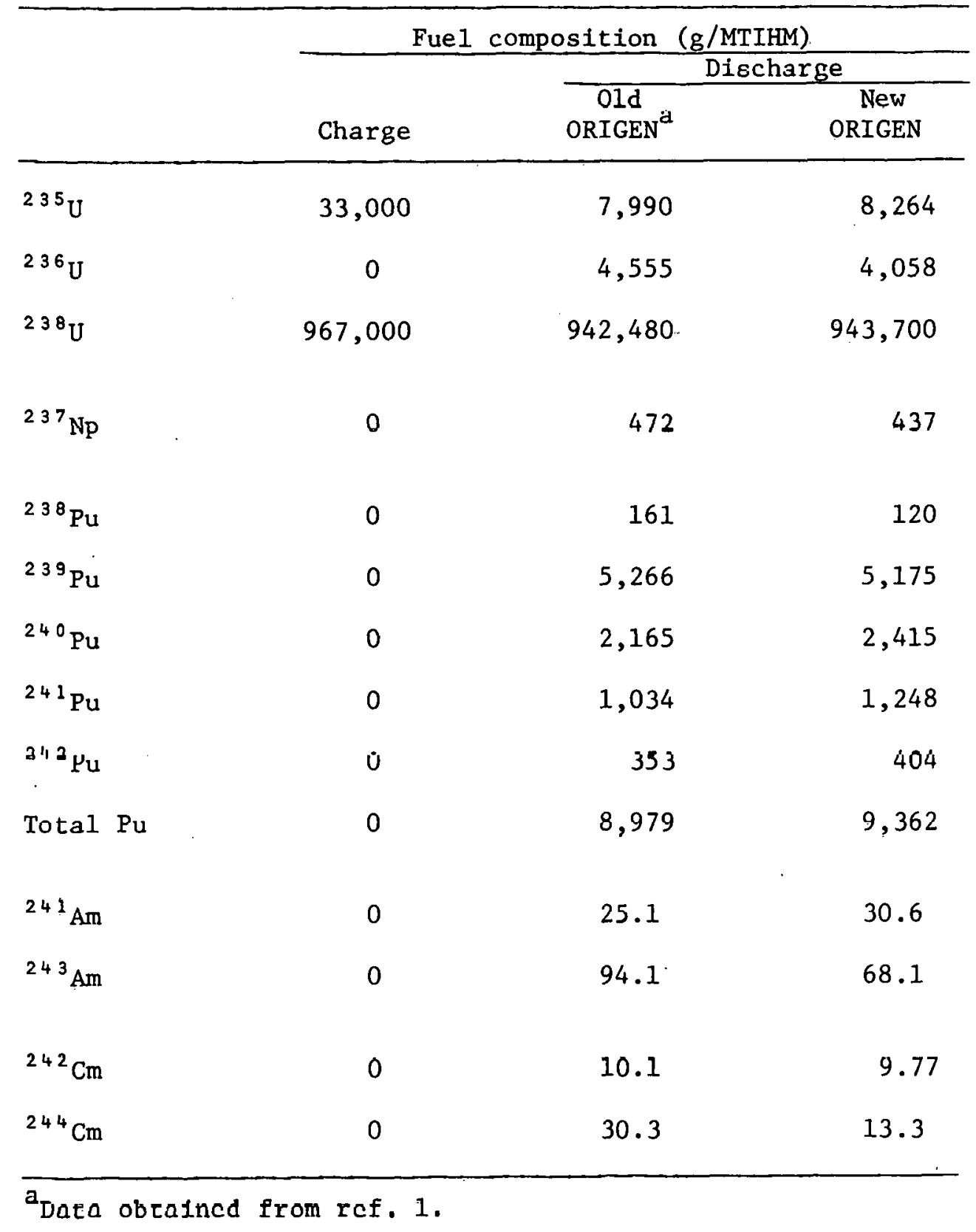


Table 6.11. Compar1son of ORIGEN BWR-U fuel-depletion calculations with 11terature values

\begin{tabular}{|c|c|c|c|c|c|c|c|c|c|c|c|}
\hline \multirow[b]{2}{*}{ Nuclide } & \multirow{2}{*}{\multicolumn{11}{|c|}{ 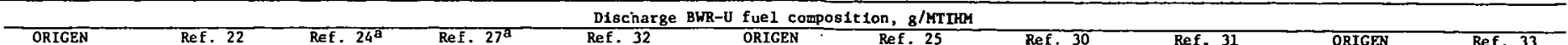 }} \\
\hline & & & & $\overline{\operatorname{ReF}} .27^{\mathrm{a}}$ & $\operatorname{Ref} .32$ & ORICEN & Ref. 25 & Ref. 30 & Ref. 31 & $\overline{\text { ORIGEN }}$ & Ref. 33 \\
\hline${ }^{234} \mathrm{U}$ & $\begin{array}{c}157 \\
(D=90)^{b}\end{array}$ & $\begin{array}{c}140 \\
(D=107)\end{array}$ & $\begin{array}{l}140 \\
(-)\end{array}$ & $\stackrel{27}{:-1}$ & $\begin{array}{l}- \\
(-)\end{array}$ & $\left(\begin{array}{c}154 \\
=93)\end{array}\right.$ & $\frac{-}{(-)}$. & $i-$ & - & $\dot{(-)}$ & $\frac{-}{(-)}$ \\
\hline $235 \mathrm{U}$ & $\begin{array}{c}7522 \\
\text { (D) } \\
19,978)^{b}\end{array}$ & $\begin{array}{c}7657 \\
\text { (D) }=19,843)\end{array}$ & $(-)$ & $\begin{aligned} & 7680 \\
(D & 19,820)\end{aligned}$ & $\begin{array}{c}7301 \\
\text { (D }=20,099)\end{array}$ & $\begin{array}{c}6608 \\
(D=18,994)\end{array}$ & $\begin{array}{c}6400 \\
(D=19,300)\end{array}$ & $\begin{array}{c}6: 09 \\
(D=19,391)\end{array}$ & $\begin{array}{c}7002 \\
(D=18,597)\end{array}$ & $\begin{array}{c}10,020 \\
(D=19,980)\end{array}$ & $\begin{array}{c}9478 \\
(D=20,522)\end{array}$ \\
\hline${ }^{236} \mathrm{U}$ & 3314 & 3344 & $\$ 342$ & 3660 & - & 3134 & $3700^{c}$ & $3 \ddot{2} 23$ & 3207 & - & - \\
\hline${ }^{238} U$ & $\begin{array}{c}951,700 \\
\text { ID }=20,553)^{b}\end{array}$ & $\begin{array}{c}951,426 \\
\text { (D }=20,827)\end{array}$ & $(-)$ & $\begin{array}{c}950,000 \\
(D=22,453)\end{array}$ & - & $\begin{array}{c}952,600 \\
(D=21,553)\end{array}$ & $\begin{array}{c}953,000 \\
(D=20,700)\end{array}$ & $\begin{array}{c}954,520 \\
(D=19,033)\end{array}$ & $\begin{array}{c}952.096 \\
(1=22,051)\end{array}$ & $\dot{-i}$ & $\overline{(-)}$ \\
\hline${ }^{237} \mathrm{~Np}$ & 338 & 360 & 362 & 368 & - & - & - & - & - & - & - \\
\hline $2{ }^{238} \mathrm{Pu}$ & $\frac{93.2}{(1.1 \mathrm{x}) \mathrm{d}}$ & $\begin{array}{l}109 \\
(1.38)\end{array}$ & $\begin{array}{l}109 \\
01.38)\end{array}$ & $\begin{array}{l}120 \\
(1.4 \pi)\end{array}$ & $(-)$ & $\begin{array}{l}97.4 \\
(1.1 z)\end{array}$ & $\begin{array}{l}155 \\
(1.97)\end{array}$ & $(-)$ & $\therefore$ & $(-)$ & - \\
\hline${ }^{239} \mathrm{Pu}$ & ${ }_{(56.9 z)^{d}}^{4831}$ & $\begin{array}{l}4905 \\
(58.1 z)\end{array}$ & $\begin{array}{l}5070 \\
(60.2 \pi)\end{array}$ & $\begin{array}{l}5260 \\
(613.6 x)\end{array}$ & $\begin{array}{l}- \\
(-)\end{array}$ & $\begin{array}{c}4856 \\
(56.07)\end{array}$ & $\begin{array}{l}4630 \\
(56.97)\end{array}$ & $\begin{array}{l}4212 \\
(57.08)\end{array}$ & $\begin{array}{l}4266 \\
(56.32)\end{array}$ & $\overline{(-)}$ & $(-)$ \\
\hline${ }^{2 * 0} \mathrm{Pu}$ & $(24.7 z)^{d}$ & $\begin{array}{l}2067 \\
(24.58)\end{array}$ & $\begin{array}{l}z 064 \\
(z 4.0 z)\end{array}$ & $\begin{array}{c}2.980 \\
(24.0 z)\end{array}$ & $(-)$ & $\begin{array}{c}2149 \\
(24.8 x)\end{array}$ & $\begin{array}{c}20<0 \\
(25.1 z)\end{array}$ & $\begin{array}{c}1753 \\
(23.78)\end{array}$ & $\begin{array}{c}1813 \\
(23.97)\end{array}$ & $(-)$ & $\begin{array}{l}- \\
(-)\end{array}$ \\
\hline${ }^{241} \mathrm{Pu}$ & $\underset{(12.9 z)^{d}}{1094}$ & $\begin{array}{l}1025 \\
(12.1 z)\end{array}$ & $\begin{array}{l}1020 \\
(11.97)\end{array}$ & $\begin{array}{c}930 \\
(19.7 x)\end{array}$ & - & $\cdot \begin{array}{c}1143 \\
(13.22)\end{array}$ & $\begin{array}{c}935 \\
(11.58)\end{array}$ & $\begin{array}{c}991 \\
(13.4 z)\end{array}$ & $\begin{array}{l}1023 \\
(13.5 \pi)\end{array}$ & $(-)$ & $(-)$ \\
\hline${ }^{242} \mathrm{Pu}$ & $(4.5 z)^{379}$ & $\begin{array}{c}335 \\
(4.0 x)\end{array}$ & $\begin{array}{c}338 \\
13.97)\end{array}$ & $\begin{array}{l}294 \\
(3.4 x)\end{array}$ & $(-)$ & $\begin{array}{c}418 \\
(4.8 z)\end{array}$ & $\begin{array}{c}378 \\
(4.67)\end{array}$ & $\begin{array}{l}428 \\
(5.87)\end{array}$ & $\begin{array}{l}470 \\
(6.2 z)\end{array}$ & $\overline{(-)}$ & $\frac{-}{(-)}$ \\
\hline Fissile Pu & $\begin{array}{c}5925 \\
(69.7 \pi)\end{array}$ & $\begin{array}{l}5930 \\
(70.38)\end{array}$ & $\begin{array}{l}6090 \\
(=0.87)\end{array}$ & $\begin{array}{l}61.90 \\
(7 L .38)\end{array}$ & $\begin{array}{c}5648 \\
(-)\end{array}$ & $\begin{array}{r}5999 \\
(69.2 \pi)\end{array}$ & $\begin{array}{c}556.5 \\
(68.48)\end{array}$ & $\begin{array}{l}5203 \\
(70.58)\end{array}$ & $\begin{array}{c}5289 \\
(69.87)\end{array}$ & $\begin{array}{c}5636 \\
(72.0 z)\end{array}$ & $\begin{array}{c}5638 \\
(69.3 x)\end{array}$ \\
\hline Total Pu & 8496 & 8441 & $\varepsilon 601$ & 8584 & - & 8664 & $81 \vdots 8$ & 7385 & 7578 & 7832 & 8130 \\
\hline${ }^{241} \mathrm{Am}$ & 36.1 & 53.8 & $\$ 4.0$ & 42.1 & - & 37.6 & - & - & - & - & - \\
\hline${ }^{243} \mathrm{Am}$ & 63.7 & 62.7 & $\epsilon 2.8$ & 71.5 & - & 73.9 & - & - & - & - & - \\
\hline${ }^{24}{ }^{2} \mathrm{Cm}$ & 10.2 & 14.1 & 4.3 & 4.5 & - & 11.1 & - & - & - & - & - \\
\hline${ }^{246} \mathrm{Cg}$. & 12.8 & 16.0 & 15.6 & 23.2 & - & 15.6 & - & - & - & - & - \\
\hline $\begin{array}{l}\text { Initial en- } \\
\text { richment } \\
\text { wt } z=3 s_{-j}\end{array}$ & 2.75 & 2.75 & $?$ & 2.73 & 2.74 & $2: 56$ & 2.57 & 2.60 & 2.56 & 3.0 & 3.0 \\
\hline $\begin{array}{l}\text { Burnup, } \\
\text { Mwd (t:/tonne } \\
\text { heavy metal }\end{array}$ & 27,500 & 27,500 & $?$ & 27,500 & 29,0148 & 27,500 & 27,500 & 27,037 & $2 i, 500$ & 25,172 & 25,000 \\
\hline
\end{tabular}

${ }^{a}$ Spent fuel composition after a decay time of 150 dars. This will reduce the amount cf ${ }^{202} \mathrm{Cll}$ present by $\imath 19 \mathrm{~g} / \mathrm{MTIHM}$.

bindicates depletion of isotope in s/MTIHM.

${ }^{c}$ Initiai composition contained $600 \mathrm{~g}^{236} \mathrm{U} / \mathrm{MTIHM}$.

d dsotop:c composition of plutonium as a weight percestage. 
Table 4.12. Comparison of ORIGEN PWR-PuU fuel-depletion calculations with literature values

\begin{tabular}{|c|c|c|}
\hline \multirow[b]{2}{*}{ Nuclide } & \multicolumn{2}{|c|}{$\begin{array}{l}\text { Discharged PWR-PuU fuel } \\
\text { composition (g/MTIHM) }\end{array}$} \\
\hline & ORIGEN & Ref. 29 \\
\hline $23{ }^{4} U$ & $\overline{(-)}$ & $\overline{(-)}$ \\
\hline${ }^{235} \mathrm{U}$ & $\begin{array}{c}8991 . \\
(D=22,009)^{a}\end{array}$ & $\begin{array}{c}8674 \\
(D=22,331)\end{array}$ \\
\hline${ }^{235} \mathrm{U}$ & 3669 & - \\
\hline $2{ }^{38} \mathrm{U}$ & $\begin{array}{c}946,200 \\
(D=20,800) .\end{array}$ & $\begin{array}{c}946,174 \\
(D=22,821)\end{array}$ \\
\hline $237 \mathrm{~Np}$ & 413 & - \\
\hline $2{ }^{3}{ }^{A} \mathrm{Pu}$ & $\dot{(-)}$ & $\overline{(-)}$ \\
\hline $239 \mathrm{Pu}$ & $\begin{array}{l}5524^{\prime} \\
(59.3 \%)^{b}\end{array}$ & $\begin{array}{l}5338 \\
(58.5 \%)\end{array}$ \\
\hline${ }^{24}{ }^{\circ} \mathrm{Pu}$ & $\begin{array}{c}2101 \\
(22.5 \%)\end{array}$ & $\begin{array}{l}2046 \\
(22.4 \%)\end{array}$ \\
\hline $2{ }^{41} \mathrm{Pu}$ & $\begin{array}{c}1277 \\
(13.7 \%)\end{array}$ & $\begin{array}{l}1290 \\
(14.2 \%)\end{array}$ \\
\hline $212 \mathrm{Pu}$ & $\begin{array}{c}421 \\
(4.5 \%)\end{array}$ & $\begin{array}{l}445 \\
(4.9 \%)\end{array}$ \\
\hline Hissile ru & $\begin{array}{c}6801 \\
(72.9 \%)\end{array}$ & $\begin{array}{l}6628 \\
(72.7 \%)\end{array}$ \\
\hline Toral Pu & 9323 & 9119 \\
\hline 241 Ani & 32.2 & \\
\hline${ }^{24}{ }^{3} \mathrm{Am}$ & 75.3 & - \\
\hline $242 \mathrm{~cm}$ & 10.7 & - \\
\hline${ }^{244} \mathrm{Cm}$ & 15.4 & - \\
\hline $\begin{array}{l}\text { Initial enrichment, } \\
\text { wt } \% 2{ }^{25} \mathrm{U}\end{array}$ & 3.10 & 3.10 \\
\hline Burnup, MWd $(t) /$ MTIHM & 30.197 & 30,390 \\
\hline
\end{tabular}

${ }^{a}$ Indicates depletion of isotope in $\mathrm{g} / \mathrm{MTIHM}$.

${ }^{b}$ Isotopic composition of plutonium as a weight percentage. 
Table 4.13. Comparison of ORIGEN PWR-PuPu fuel-depletion calculations with literature values

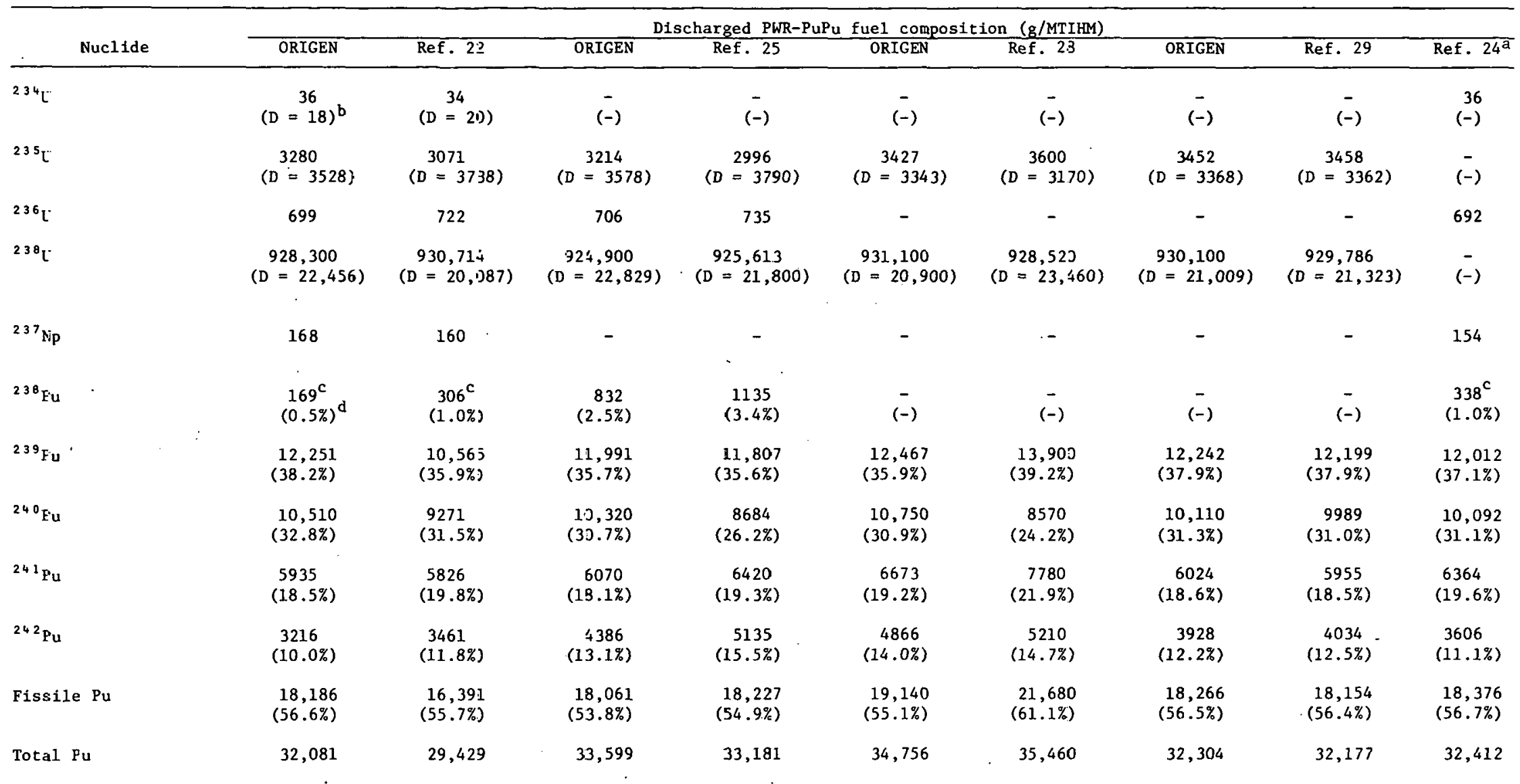


Table 4.13 (continued)

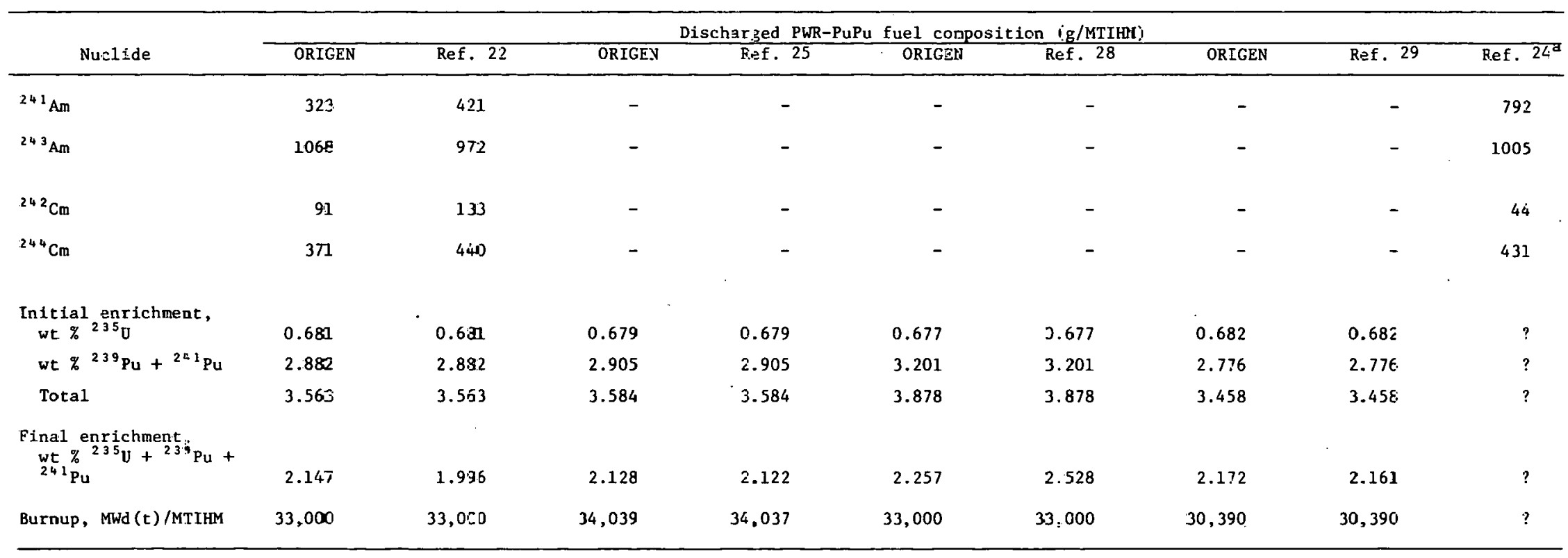
a Spent fuel composition after a decay time of $15 C$ days. This will reduce the amount of ${ }^{242}$ Cn present by abour a factor of 2 and increase the amount
of $241 \mathrm{Am}$ by $v_{\mathrm{g}}$ /MTIHM.

'Indicates deplerion of isotope in $\varepsilon / M T I H M$.

"No ${ }^{238} \mathrm{Pu}$ presen: in plutonium charged to reactor.

d Isotopic composition oz̃ plutcniur: es. a weigtt percentage. 
these numbers with each other to determine their internal consistency very difficult. However, despite this variation, the ORIGEN results agree well with nearly all of the literature values. It should be noted that the ORIGEN spent fuel compositions represent the discharge from the second plutonium recycle. When possible, second-recycle values were also selected from the literature. However, in some cases the recycle number associated with the literature spent fuel compositions was unknown, and they were used on this basis.

4.3.2.5 BWR-PuU fuel. The results of the ORIGEN depletion of the uranium-enriched portion of a self-generated plutonium-recycle BWR are given in Table 4.14. No literature comparisons were available for this fuel.

4.3.2.6 BWR-PuPu fuel. The comparison of the ORIGEN and literature spent fuel compositions for the mixed-oxide fuel in a self-generated plutonium-recycle BWR is given in Table 4.15. In an overall sense, the agreement appears to be good and similar to that obtained for the BWR-U fuel (see Table 4.11). However, close inspection shows significant differences between ORIGEN and the literature values concerning the amounts of ${ }^{239} \mathrm{Pu}$ and ${ }^{240} \mathrm{Pu}$ in the spent fuel. The source of these differences is unknown, but the use of an adjusted moderator density identical to the one used for the BWR-U fuel may be a factor.

\subsubsection{Summary description of the ORIGEN U-Pu cycle LWR models}

Fuel-depletion calculations have been performed for the six U-Pu cycle LWR fuel types considered in this report - PWR-U, PWR-PuU, PWR-PuPu, BWR-U, BWR-PuU, and BWR-PuPu - using input compositions given in Table 4.7. The results of these calculations, including irradiation conditions and 
Table 4.14. Results of ORIGEN

BWR-PuU fuel depletion

\begin{tabular}{|c|c|}
\hline Nuclide & $\begin{array}{l}\text { Discharged BWR-PuU } \\
\text { fuel composition } \\
\text { (g/MTIHM) }\end{array}$ \\
\hline $234 \mathrm{U}$ & $(D=93)^{a}$ \\
\hline${ }^{235} \mathrm{U}$ & $\begin{array}{c}7987 \\
(D=19,513)\end{array}$ \\
\hline${ }^{236} \mathrm{U}$ & 3275 \\
\hline $2{ }^{38} \mathrm{U}$ & $\begin{array}{c}950,300 \\
(D-21,053)\end{array}$ \\
\hline $23^{7} \mathrm{~Np}$ & 370.3 \\
\hline${ }^{238} \mathrm{Pu}$ & $(1.1 \%) b$ \\
\hline $239 \mathrm{Pu}$ & $\begin{array}{c}5608 \\
(59.4 \%)\end{array}$ \\
\hline${ }^{240} \mathrm{Pu}$ & $\begin{array}{c}2148 \\
(22.7 \%)\end{array}$ \\
\hline${ }^{241} \mathrm{Pu}$ & $\begin{array}{c}1211 \\
(12.8 \%)\end{array}$ \\
\hline${ }^{242} \mathrm{Pu}$ & $\begin{array}{c}374 \\
(4.0 \%)\end{array}$ \\
\hline Fissile $\mathrm{Pu}_{\mathrm{u}}$ & $\begin{array}{c}6819 \\
(12.2 \%)\end{array}$ \\
\hline Tutal Pu & 9444 \\
\hline $241 \mathrm{Am}$ & 37.9 \\
\hline${ }^{243} \mathrm{Am}$ & 70.2 \\
\hline $242 \mathrm{rm}$ & 10.9 \\
\hline $244 \mathrm{Cm}$ & 14.9 \\
\hline $\begin{array}{l}\text { Initial enrichment, } \\
\text { wt } \%{ }^{25} \mathrm{U}\end{array}$ & 2.75 \\
\hline Burnup, MWd $(t) /$ MTIHM & 27,500 \\
\hline
\end{tabular}


Table 4.15. Comparison of ORIGEN BWR-PuPu fuel-depletion calculations with literature values

\begin{tabular}{|c|c|c|c|c|c|}
\hline \multirow[b]{2}{*}{ Nuclide } & \multicolumn{5}{|c|}{ Discharged BWR-PuPu fuel composition (g/MTIHM) } \\
\hline & ORIGEN & Ref. 25 & $\operatorname{Ref} \cdot 27^{a}$ & ORIGEN & $\operatorname{Ref} .28$ \\
\hline${ }^{234} \mathrm{U}$ & $\left(\mathrm{n}=\mathrm{15}^{39} \mathrm{~b}\right.$ & $\begin{array}{c}37 \\
(D=17)\end{array}$ & $\begin{array}{r}37 \\
(-)\end{array}$ & $\overline{(-)}$ & $\overline{(-)}$ \\
\hline${ }^{235} \mathrm{U}$ & $\begin{array}{c}3295 \\
(D=3585)\end{array}$ & $\begin{array}{c}3199 \\
(D=3657)\end{array}$ & $\overline{(-)}$ & $\begin{array}{c}3111 \\
(D=3718)\end{array}$ & $\begin{array}{l}2875 \\
(D=954)\end{array}$ \\
\hline${ }^{236} \mathrm{U}$ & 678 & 707 & 687 & 700 & 749 \\
\hline $238^{2} \mathrm{U}$ & $\begin{array}{c}940,100 \\
(\nu=17,311)\end{array}$ & $\begin{array}{c}939,947 \\
(D=17,464)\end{array}$ & $\overline{(-)}$ & $\begin{array}{c}935,600 \\
(D=18,314)\end{array}$ & $\begin{array}{c}934,805 \\
(D=19,109)\end{array}$ \\
\hline $237 \mathrm{~Np}$ & 113 & 149 & 146 & - & - \\
\hline${ }^{238} \mathrm{Pu}$ & ${ }_{(0.6 \%)^{c}}^{155^{c}}$ & $\begin{array}{l}369^{c} \\
(1.4 \%)\end{array}$ & $\begin{array}{l}304^{\mathrm{c}} \\
(1.1 \%)\end{array}$ & $\begin{array}{l}821 \\
(2.9 \%)\end{array}$ & $\begin{array}{l}1196 \\
(4.2 \%)\end{array}$ \\
\hline${ }^{239} \mathrm{Pu}$ & $\begin{array}{c}9349 \\
(35.4 \%)\end{array}$ & $\begin{array}{l}9770 \\
(37.6 \%)\end{array}$ & $\begin{array}{l}10,658 \\
(38.6 \%)\end{array}$ & $\begin{array}{l}8995 \\
(31.8 \%)\end{array}$ & $\begin{array}{c}9848 \\
(34.4 \%)\end{array}$ \\
\hline $240 \mathrm{Pu}$ & $\begin{array}{c}9516 \\
(36.1 \%)\end{array}$ & $\begin{array}{l}8290 \\
(31.9 \%)\end{array}$ & $\begin{array}{l}8706 \\
(31.5 \%)\end{array}$ & $\begin{array}{c}9683 \\
(34.3 \%)\end{array}$ & $\begin{array}{c}8200 \\
(28.7 \%)\end{array}$ \\
\hline $241 \mathrm{Pu}$ & $\begin{array}{c}4537 \\
(17.2 \%)\end{array}$ & $\begin{array}{c}4724 \\
(18.2 \%)\end{array}$ & $\begin{array}{l}5027 \\
(18.2 \%)\end{array}$ & $\begin{array}{l}4788 \\
(17.0 \%)\end{array}$ & $\begin{array}{c}5002 \\
(17.5 \%)\end{array}$ \\
\hline${ }^{242} \mathrm{Pu}$ & $\begin{array}{c}2833 \\
(10.7 \%)\end{array}$ & $\begin{array}{l}2831 \\
(10.9 \%)\end{array}$ & $\begin{array}{l}2920 \\
(10.6 \%)\end{array}$ & $\begin{array}{l}3956 \\
(14.0 \%)\end{array}$ & $\begin{array}{c}4356 \\
(15.2 \%)\end{array}$ \\
\hline Fissile Pu & $\begin{array}{l}13,886 \\
(52.6 \%)\end{array}$ & $\begin{array}{l}14,494 \\
(55.8 \%)\end{array}$ & $\begin{array}{r}15.685 \\
(56.8 \%)\end{array}$ & $\begin{array}{l}13,78.3 \\
(48.8 \%)\end{array}$ & $\begin{array}{l}14,850 \\
(51.9 \%)\end{array}$ \\
\hline Total Pu & 26,390 & 25,984 & 27,615 & 28,243 & 28,602 \\
\hline${ }^{241} \mathrm{Am}$ & 304 & 508 & 639 & - & - \\
\hline $243 \mathrm{Am}$ & 814 & 769 & 839 & - & - \\
\hline${ }^{242} \mathrm{Cm}$ & 75.6 & 109 & 36.3 & - & - \\
\hline${ }^{244} \mathrm{Cm}$ & 244 & 329 & 32.5 & - & - \\
\hline $\begin{array}{l}\text { Intrial enrichment, } \\
\text { wt } \% 235 \mathrm{U} \text {. }\end{array}$ & 0.686 & 0.686 & $?$ & 0.683 & 0.683 \\
\hline wt $\%\left({ }^{239} \mathrm{Pu}+{ }^{241} \mathrm{Pu}\right)$ & 2.427 & 2.427 & $?$ & 2.429 & 2.429 \\
\hline Total & 3.112 & 3.112 & $?$ & 3.112 & 3.112 \\
\hline $\begin{array}{l}\text { Final enrichment, } \\
\text { wt } \%\left({ }^{235} \mathrm{U}+{ }^{239} \mathrm{Pu}+\right. \\
241 \mathrm{Pu})\end{array}$ & 1.717 & 1.769 & $?$ & 1.689 & 1.773 \\
\hline Burnup, MWd (t)/MTIHM. & 27,500 & 27,500 & $?$ & 29,490 & 29,490 \\
\hline
\end{tabular}

${ }^{a}$ Spent fuel composition after a decay time of 150 days. This will reduce the amount of $242 \mathrm{Cm}$ present by about a factor of 2 and increase the amount of ${ }^{241} \mathrm{Am}$ by $\sim 9 \mathrm{~g} / \mathrm{MTIHM}$.

${ }^{b}$ Indicates depletion of isotope in g/MTIHM.

${ }^{\mathrm{C}}$ No ${ }^{23 \mathrm{P}} \mathrm{Pu}$ present in plutonium charged to reactor.

${ }^{d}$ Isotopic composition of plutonium as a weight percentage. 
measures of the uranium and plutonium contents of the fresh and spent fuels, are given in Table 4.16. Many of the values in this table are given in terms of both kilograms per cycle and kilograms per year, assuming an $80 \%$ capacity factor for the latter. 
Table 4.16. Summary of ORIGEN LWR model characteristics

\begin{tabular}{|c|c|c|c|c|c|c|c|c|}
\hline \multirow[b]{2}{*}{ Parameter } & \multirow[b]{2}{*}{ PWR-U } & \multicolumn{3}{|c|}{ PiNR-Pu } & \multirow[b]{2}{*}{ BWR-U } & \multicolumn{3}{|c|}{$\mathrm{BWR}-\mathrm{Pu}$} \\
\hline & & $\overline{\mathrm{PWR}-\mathrm{PuU}}$ & PWR-PuPu & Total & & $\overline{\text { BWR-PuU }}$ & BWR-PuPu & Total \\
\hline Electric power. MW(e) & 1250 & 875 & 375 & 1250 & 1250 & 875 & 375 & 1250 \\
\hline Thermal power, MW(t) & 3800 & 2660 & 1140 & 3800 & 3800 & 2660 & 1140 & 3800 \\
\hline $\begin{array}{l}\text { Average specific power, } \\
\text { MW(t)/MTIHM }\end{array}$ & 37.5 & 37.5 & 37.5 & 37.5 & 25.9 & 25.9 & 25.9 & 25.9 \\
\hline $\begin{array}{l}\text { Average fuel burnup: } \\
\text { MWd/MTIHMB }\end{array}$ & 33,000 & 33,000 & 33,000 & 33,000 & 27,500 & 27,500 & 27,500 & 27,500 \\
\hline $\begin{array}{l}\text { Irradiation duration, } \\
\text { full-power days }\end{array}$ & 880 & 880 & 880 & 880 & 1062 & 1062 & 1062 & 1062 . \\
\hline $\begin{array}{l}\text { Refueling cycle length, } \\
\text { full-power days }\end{array}$ & 293.3 & 293.3 & 293.3 & 293.3 & 265.5 & 265.5 & 265.5 & 265.5 \\
\hline days at $80 \%$ sapacity factor & 367 & 367 & 367 & 367 & 332 & 332 & 332 & 332 \\
\hline $\begin{array}{l}\text { Charge, } \mathrm{kg} / \text { refueling cycle } \\
\quad(\mathrm{kg} / \text { year at } 30 \% \text { capacity factor) }\end{array}$ & & & - & & & & & \\
\hline${ }^{235} \mathrm{U}$ & $\begin{array}{c}1081 \\
(1077)\end{array}$ & $\begin{array}{l}757 \\
(754)\end{array}$ & $\begin{array}{c}68.8 \\
(68.6)\end{array}$ & $\begin{array}{c}826 \\
(823)\end{array}$ & $\begin{array}{c}1009 \\
(1110)\end{array}$ & $\begin{array}{l}706 \\
(777)\end{array}$ & $\begin{array}{c}75.2 \\
(82.7)\end{array}$ & $\begin{array}{c}781 \\
(860)\end{array}$ \\
\hline Total U & $\begin{array}{c}33,778 \\
(33,647)\end{array}$ & $\begin{array}{c}23,644 \\
(23,553)\end{array}$ & $\begin{array}{c}9674 \\
(9636)\end{array}$ & $\begin{array}{c}33,318 \\
(33,189)\end{array}$ & $\begin{array}{l}36,680 \\
(40,369)\end{array}$ & $\begin{array}{c}25,676 \\
(28,258)\end{array}$ & $\begin{array}{c}10,572 \\
(11,636)\end{array}$ & $\begin{array}{c}36,248 \\
(39,894)\end{array}$ \\
\hline Fissile $\mathrm{Pu}^{\mathrm{C}}$ & $\begin{array}{c}0 \\
(0)\end{array}$ & $\begin{array}{c}0 \\
(0)\end{array}$ & $\begin{array}{c}294 \\
(293)\end{array}$ & $\begin{array}{c}294 \\
(293)\end{array}$ & $\begin{array}{c}0 \\
(0)\end{array}$ & $\begin{array}{c}0 \\
(0)\end{array}$ & $\begin{array}{c}267 \\
(294)\end{array}$ & $\begin{array}{l}267 \\
(294)\end{array}$ \\
\hline Total $\mathrm{Pu}^{\mathrm{d}}$ & $\begin{array}{c}0 \\
(0)\end{array}$ & $\begin{array}{c}0 \\
(0)\end{array}$ & $\begin{array}{l}460 \\
(459)\end{array}$ & $\begin{array}{l}460 \\
(459)\end{array}$ & $\begin{array}{c}0 \\
(0)\end{array}$ & $\begin{array}{c}0 \\
(0)\end{array}$ & $\begin{array}{c}432 \\
(475)\end{array}$ & $\begin{array}{c}432 \\
(475)\end{array}$ \\
\hline Total $(U+P u)$ & $\begin{array}{c}33,778 \\
(33,647)\end{array}$ & $\begin{array}{c}23,644 \\
(23,553)\end{array}$ & $\begin{array}{l}10,134 \\
(10,095)\end{array}$ & $\begin{array}{c}33,778 \\
(33,648)\end{array}$ & $\begin{array}{c}36,580 \\
(40,369)\end{array}$ & $\begin{array}{c}25,676 \\
(28,258)\end{array}$ & $\begin{array}{c}11,004 \\
(12,111)\end{array}$ & $\begin{array}{l}36,680 \\
(40,369)\end{array}$ \\
\hline
\end{tabular}


Table 4.16 (continued)

\begin{tabular}{|c|c|c|c|c|c|c|c|c|}
\hline \multirow[b]{2}{*}{ Parameter } & \multirow[b]{2}{*}{ PWR-U } & \multicolumn{3}{|c|}{ PWR-Pu } & \multirow[b]{2}{*}{ BWR-U } & \multicolumn{3}{|c|}{$\mathrm{BWR}-\mathrm{Pu}$} \\
\hline & & PWR-PuU & PWR-PuPu & Total & & BWR-PuU & BWR-PuPu & Total \\
\hline \multicolumn{9}{|l|}{$\begin{array}{l}\text { Discharge, kg/refuelirg cycle } \\
\text { (kg/year at } 80 \% \text { capa:ity factor) }\end{array}$} \\
\hline $235_{U}$ & $\begin{array}{c}267 \\
(266)\end{array}$ & $\begin{array}{c}199 \\
(198)\end{array}$ & $\begin{array}{c}33.5 \\
(33.4)\end{array}$ & $\begin{array}{c}233 \\
(231)\end{array}$ & $\begin{array}{c}276 \\
(304)\end{array}$ & $\begin{array}{c}205 \\
(226)\end{array}$ & $\begin{array}{c}36.7 \\
(40.4)\end{array}$ & $\begin{array}{c}242 \\
(266)\end{array}$ \\
\hline Total U & $\begin{array}{c}32,173 \\
(32,048)\end{array}$ & $\begin{array}{c}22,592 \\
(22,504)\end{array}$ & $\begin{array}{c}9422 \\
(9385)\end{array}$ & $\begin{array}{c}32: 014 \\
(31: 889)\end{array}$ & $\begin{array}{l}35,319 \\
(38,872)\end{array}$ & $\begin{array}{c}24,693 \\
(27,177)\end{array}$ & $\begin{array}{l}10,356 \\
(1 i, 398)\end{array}$ & $\begin{array}{c}35,049 \\
(38,575)\end{array}$ \\
\hline Fissile $\mathrm{Pu}^{\mathrm{C}}$ & $\begin{array}{c}210 \\
(209)\end{array}$ & $\begin{array}{c}164 \\
(163)\end{array}$ & $\begin{array}{c}186 \\
(185)\end{array}$ & $\begin{array}{c}350 \\
(: 48)\end{array}$ & $\begin{array}{c}217 \\
(239)\end{array}$ & $\begin{array}{l}175 \\
(193)\end{array}$ & $\begin{array}{l}157 \\
(173)\end{array}$ & $\begin{array}{c}332 \\
(366)\end{array}$ \\
\hline Total Pu & $\begin{array}{c}308 \\
(307)\end{array}$ & $\begin{array}{c}232 \\
(231)\end{array}$ & $\begin{array}{c}344 \\
(342)\end{array}$ & $\begin{array}{c}576 \\
(573)\end{array}$ & $\begin{array}{c}309 \\
(340)\end{array}$ & $\begin{array}{c}242 \\
(267)\end{array}$ & $\begin{array}{c}318 \\
(350)\end{array}$ & $\begin{array}{c}560 \\
(617)\end{array}$ \\
\hline Total $(\mathrm{U}+\mathrm{Pu})$ & $\begin{array}{l}32,481 \\
(32,354)\end{array}$ & $\begin{array}{l}22,824 \\
(22,735)\end{array}$ & $\begin{array}{c}9766 \\
(9727)\end{array}$ & $\begin{array}{l}32,590 \\
(32,462)\end{array}$ & $\begin{array}{l}35,628 \\
39,212)\end{array}$ & $\begin{array}{l}24,935 \\
(27,444)\end{array}$ & $\begin{array}{l}10,674 \\
(11,748)\end{array}$ & $\begin{array}{c}35,609 \\
(39,192)\end{array}$ \\
\hline Total heavy metal & $\begin{array}{c}32,503 \\
(32,376)\end{array}$ & $\begin{array}{c}22,840 \\
(22,751)\end{array}$ & $\begin{array}{c}9795 \\
(9756)\end{array}$ & $\begin{array}{c}32,635 \\
(32,507)\end{array}$ & $\begin{array}{c}35,647 \\
: 39,233)\end{array}$ & $\begin{array}{c}24,949 \\
(27,459)\end{array}$ & $\begin{array}{c}10,697 \\
(11,773)\end{array}$ & $\begin{array}{c}35,646 \\
(39,232)\end{array}$ \\
\hline
\end{tabular}

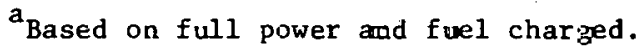

$\mathrm{b}_{\text {MTIHM }}=$ metric ton of initial heary metal.

$\mathrm{C}_{239} \mathrm{Pu}+241 \mathrm{Pu}+{ }^{239} \mathrm{~Np}$.

$\mathrm{d}^{238} \mathrm{Pu}+{ }^{239} \mathrm{Pu}+{ }^{240} \mathrm{Pu}+{ }^{241} \mathrm{Pu}+{ }^{24 \cdot 2} \mathrm{Pu}+{ }^{239} \mathrm{~Np}$. 


\subsection{References for Sect. 4}

1. M. J. Be11, ORIGEN - The ORNL Isotope Generation and Depletion Code, ORNL-4628 (Mày 1973).

2. N. M. Greene, J. L. Lucius, L. M. Petrie, W. E. Ford III, J. E. White, and R. Q. Wright, AMPX: A Modular Code System for Generating Coupled Multigroup Neutron-Gamma Libraries from ENDF/B, ORNL/TM-3706 (March 1976).

3. N. M. Levitz, B. J. Kullen, and M. J. Steindler, Management of Waste Cladding Hulls. Part I. Pyrophoricity and Compaction, ANL-8139 (February 1975).

4. W. Davis, Jr., Carbon-14 Production in Nuclear Reactors, ORNL/NUREG/TM-12 (February 1977).

5. The Superalloys, Chester T. Sims and William C. Hagel, eds., Wiley, 1972.

6. "Manufacturing Program," technical literature distributed by Techalloy Company, Inc., Rahns, Pa. (December 1972).

7. G. R. Kilp, Westinghouse Electric Corporation, persọnal communication, July 1977 .

8. R. H. Perry, C. H. Chilton, and S. D. Kirkpatrick, Chemical Engineers' Handbook, 4th ed., McGraw-Hill, 1963.

9. Wall-Colmonoy Corp., Detroit, Mich., personal communication, 1976.

10. D. E. Delwiche, General Electric Corporation, personal communication, November 1977.

11. G. R. Kilp, Westinghouse Electric Corporation, personal communication, December 1975 . 
12. G. R. Kilp, Westinghouse Electric Corporation, personal communication, July 1977 .

13. M. O. Marlowe, General Electric Corporation, personal communication, February 1976.

14. D. E. Delwiche, General Electric Corporation, personal communication, September 1977.

15. General Electric Standard Safety Analysis Report, BWR/6, DOCKET STN 50-447 (1973).

16. Westinghouse Nuclear Energy Systems, RESAR-3, Reference Safety Analysis Report, DOCKET STN 50-480 (1972).

17. G. LaPier, Babcock and Wilcox Corp., Nuclear Materials Division, personal communication, May 9, 1978.

18. General Electric Corporation, Plutonium Utilization in Boiling Water Reactors: Phase II Semi-Annual Report, January-June 1971, NEDC-10586 (December 1971).

19. L. G. Wisnyi, LWB/LSBR Development Porgram: High Cross-Section Impurities in Reactor Corc Matcrialo; KAPL-3322 (June 1067).

20. Y. B. Katayama, Leaching of Irradiated LWR Fuel Pellets in Deionized and Typical Ground Water, BNWL-2057 (July 1976).

21. T. B. Fowler, D. R. Vondy, and G. W. Cunningham, Nuclear Reactor Core Analysis Code: CITATION, ORNL/TM-2496, Rev. 2 (July 1971).

22. Pacific Northwest Laboratories, Theoretical Analysis of Plutonium Bu1ldup and Uranium Depletion in Pressurized Water and Boiling Water Power Reactors, Report Y49024 to IAEA Division of Nuclear Power Reactors (July 1968). 
23. B. L. Vondra, LWR Fuel Reprocessing and Recycle Program Quarterly Report for Period April 1 to June 30, 1976, ORNL/TM-5547 (July 1976).

24. R. W. Bown, USAEC Office of Planning and Analysis, personal communication to A. M. Perry, November 1974 .

25. D. E. Deonigi, Battelle Pacific Northwest Laboratories, personal communication to J. P. Nichols concerning mass flow data for light water reactors with plutonium recycle, May 1972.

26. W. B. Arthur, Union Carbide Corporation Nuclear Division, personal communication concerning charge/discharge data for a PWR, March 1977.

27. E. Schmidt, Predictions for the High-Level Alpha-Active Waste to be Generated by Nuclear. Power Stations in the Member States of the European Communities, EUR 5690e (1976).

28. Westinghouse Electric Corporation, Economic Utilization of Plutonium in Pressurized Water Reactors, WCAP-7160 (February 1968).

29. T. M. Helm, M. R. Shay, R. W. Hardie, and R. P. Omberg, eds., Reactor Design Characteristics and Fuel Inventory Data, IIEDL, unnumbered report (September 1977).

30. B. I. Vondra, LWR Fuel Reprocessing and Recycle Program Quarterly Report for Period July 1 to September 30, 1976, ORNL/TM-5660 (November 1976).

31. W. B. Arthur, Union Carbide Corporation, Nuclear Division, personal communication concerning charge/discharge data for a BWR, March 1977. 
32. R. J. Mullin, Tennessee Valley Authority, personal communication to J. T. Bradbury, February 11, 1977.

33. H. E. Williamson, Appraisal of BWR Plutonium Burners for Energy Centers, GEAP-11367 (January 1976). 


\section{APPENDIX A:}

84-ENERGY-GROUP NEUTRON SPECTRA GRAPHS AND LISTINGS 
APPENDIX A: 84-ENERGY-GROUP NEUTRON SPECTRA GRAPHS AND LISTINGS

This appendix contains graphs and listings of 84-energy-group neutron spectra for the six U-Pu cycle LWR fuel types considered in this report as calculated by the XSDRNPM code. The units of the neutron fluxes in this appendix are flux per unit lethargy. The PWR-U and BWR-U spectra are pin-cell-averaged; the PWR-PuU, PWR-PuPu, BWR-PuU, and BWR-PuPu spectra are averaged over the zone in the assembly-cell model containing the fuel type of interest (see Sect. 3.3.2). 


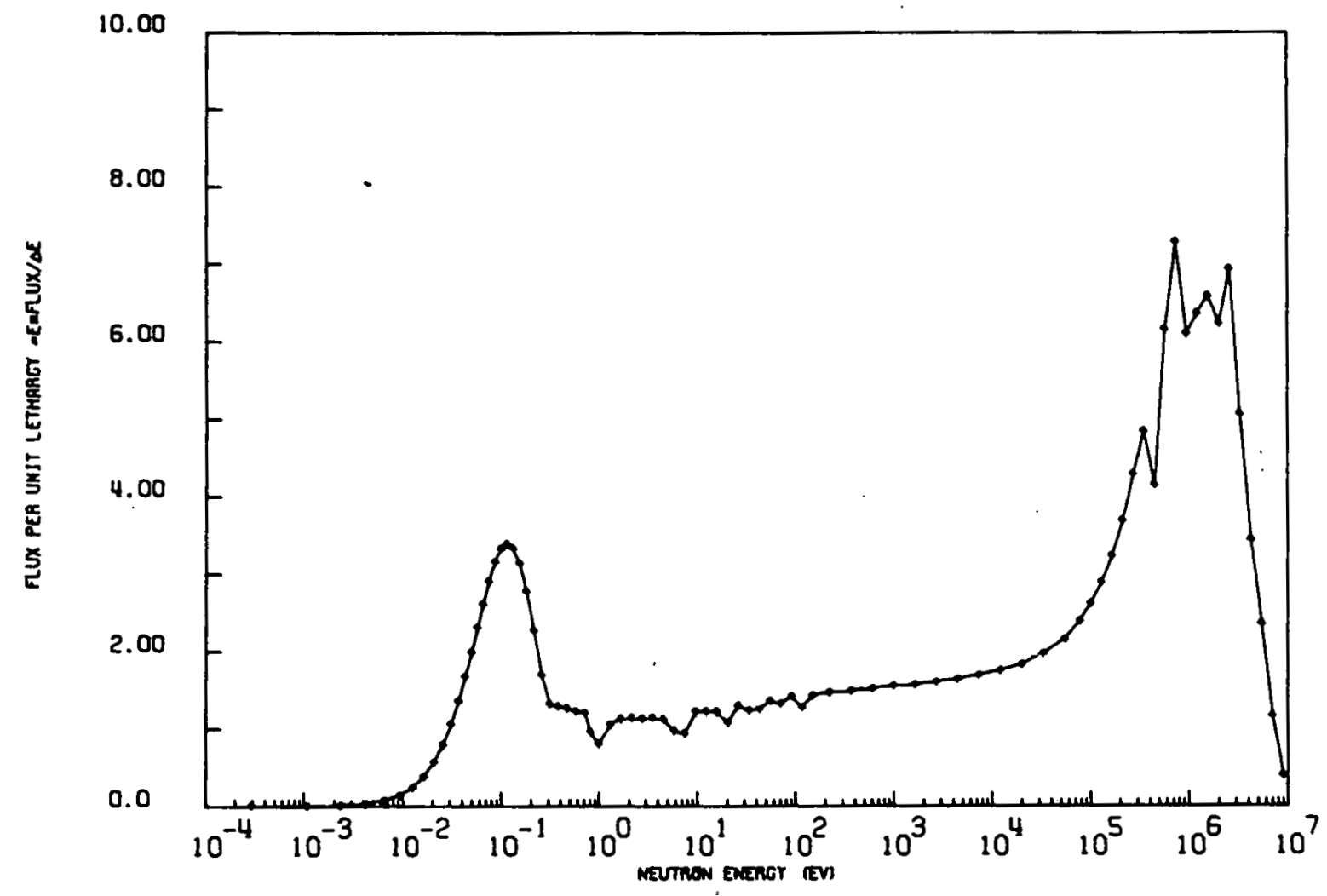

Fig. A.1. Neutron energy spectrum in a PWR-U. 


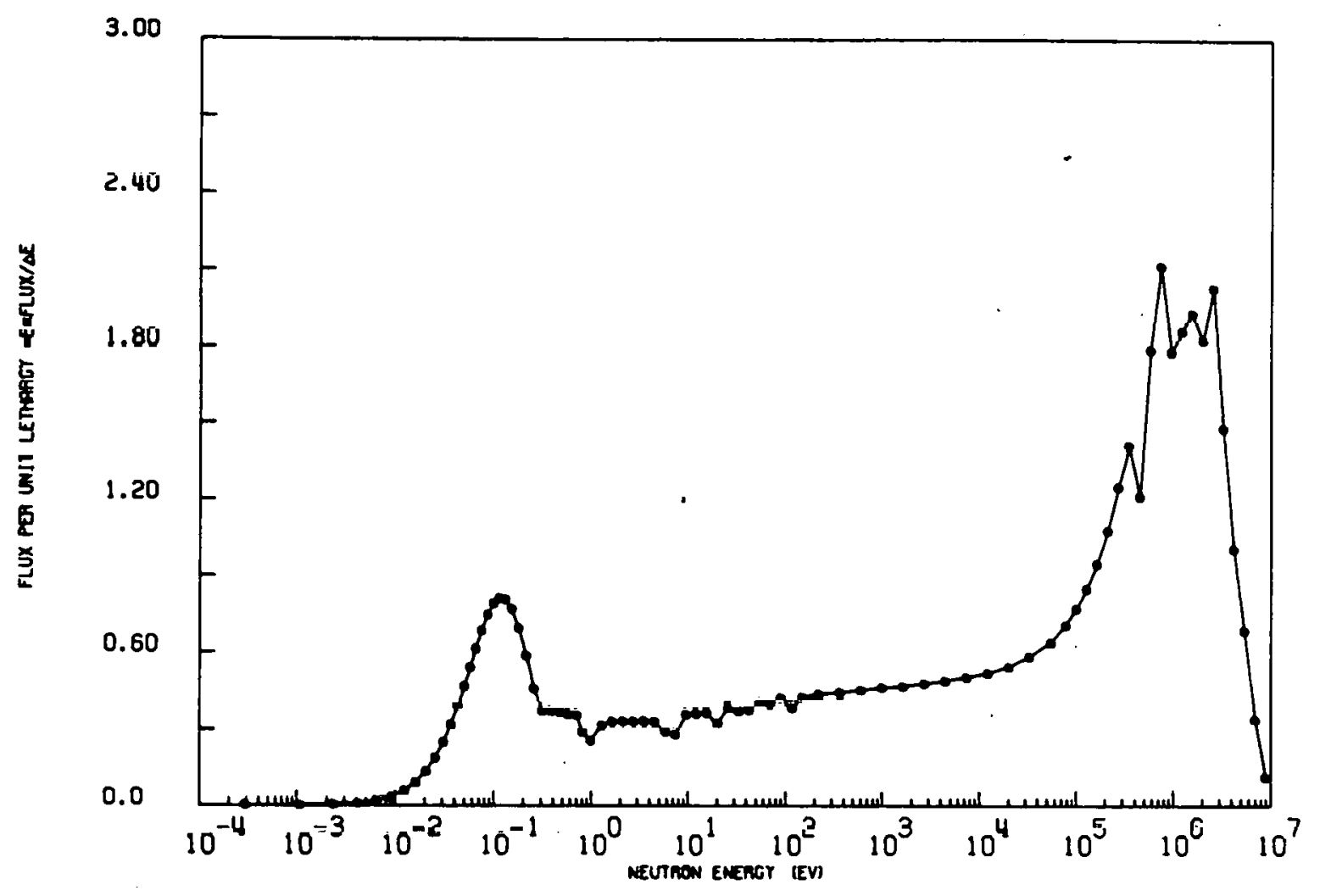

Fig. A.2. Neutron energy spectrum in a PWR-PuU. 


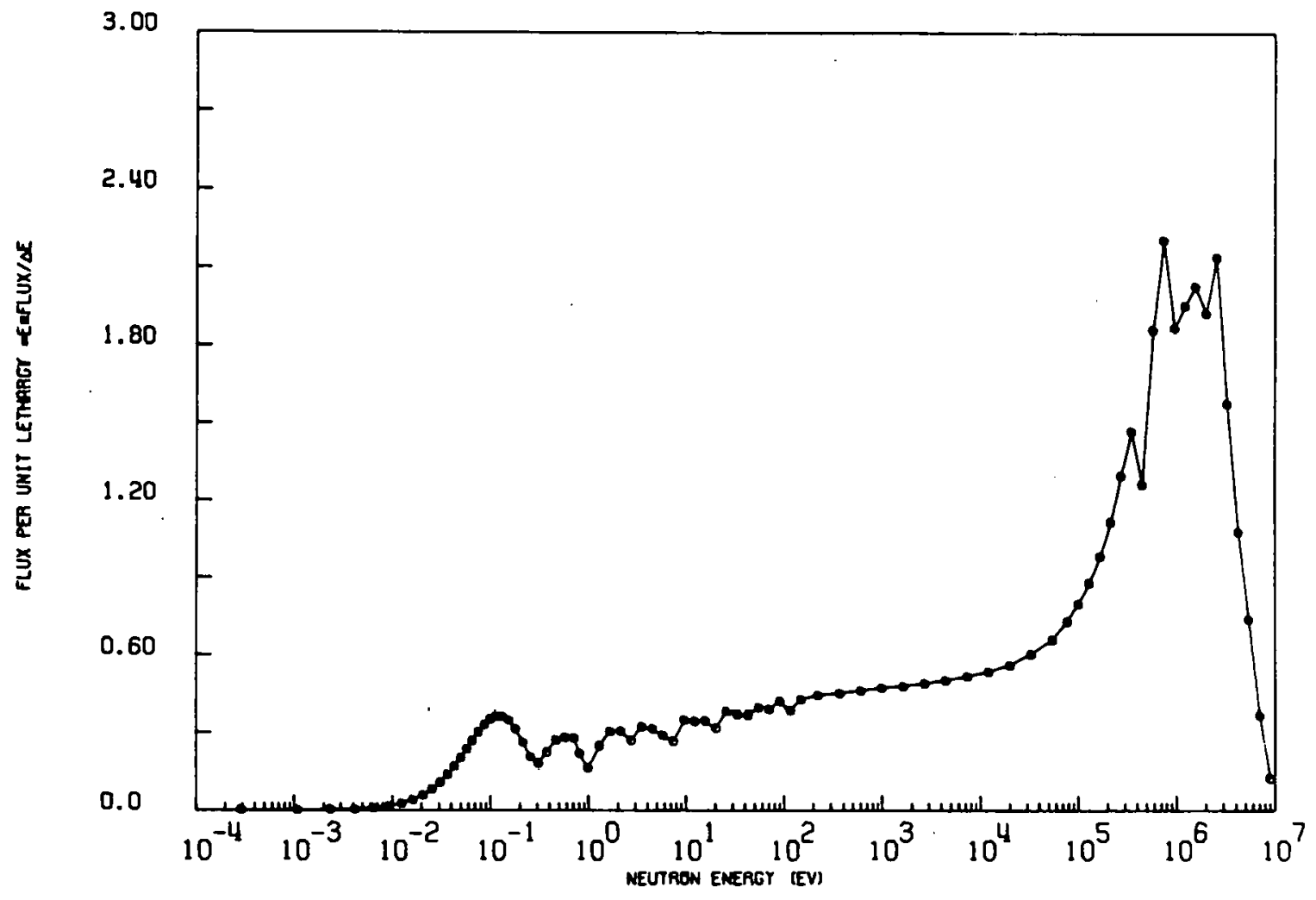

Fig. A.3. Neutron energy spectrum in a PWR-PuPu. 


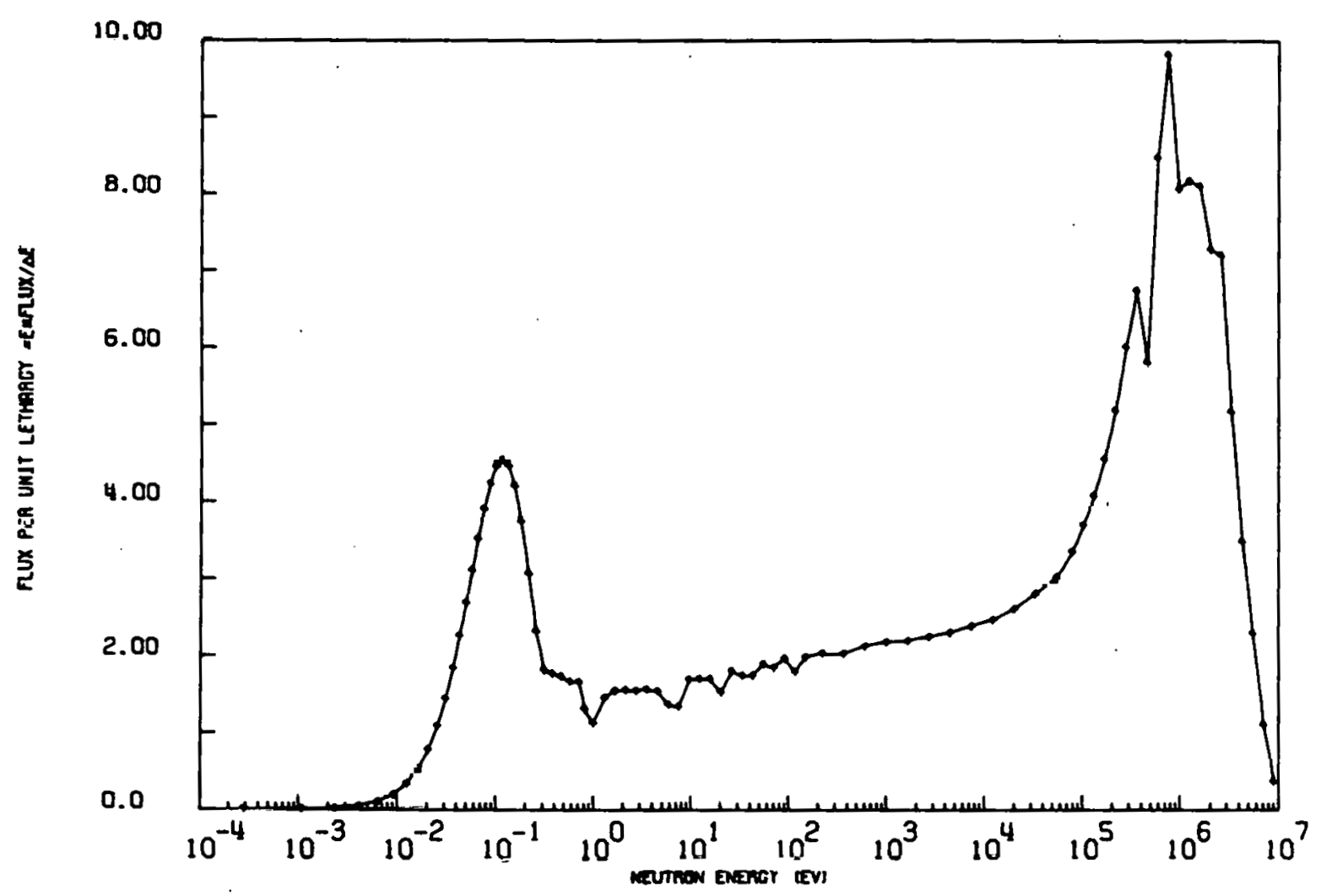

Fig. A.4. Neutron energy spectrum in a BWR-U. 


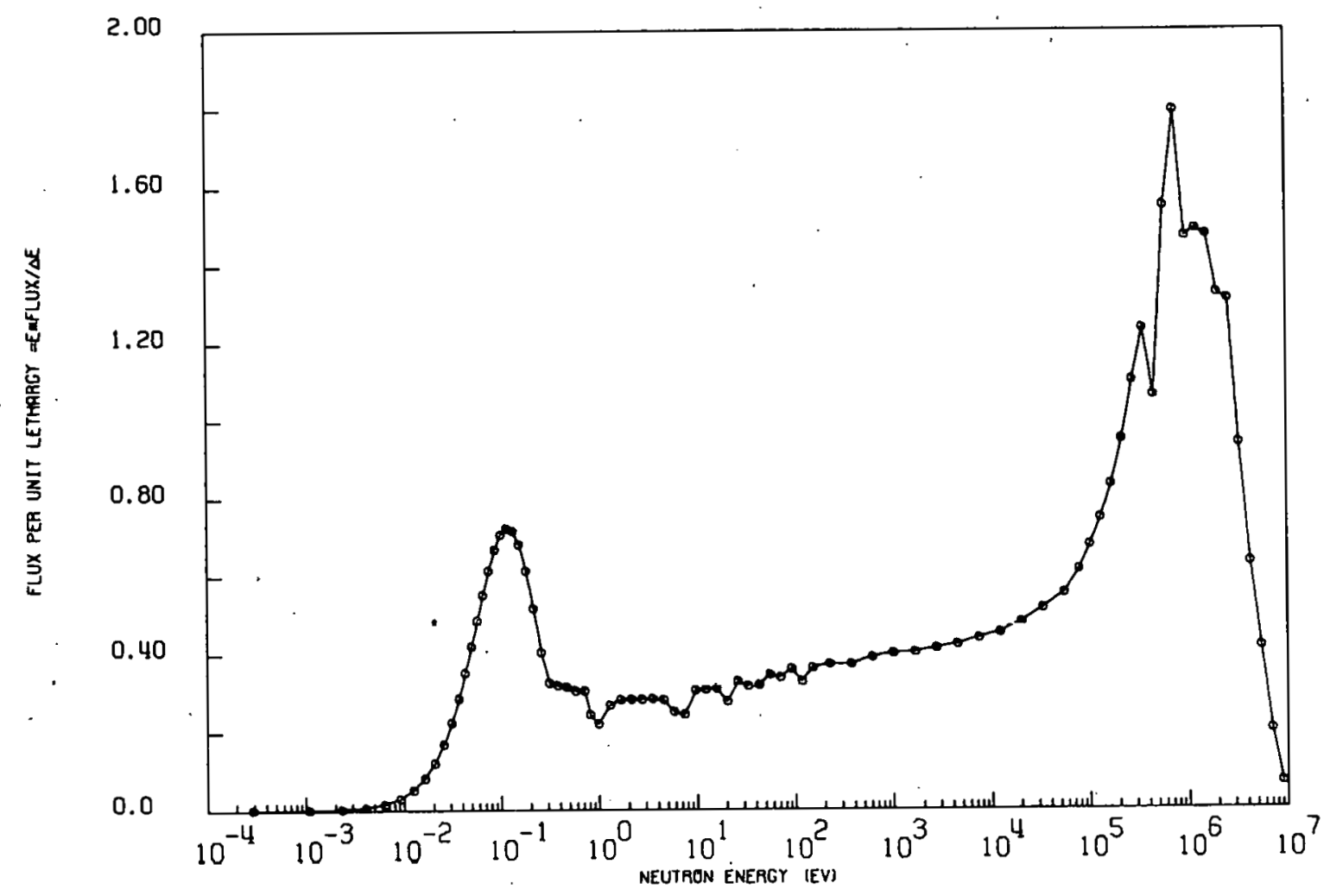

Fig. A.5. Neutron energy spectrum in a BWR-PuU. 


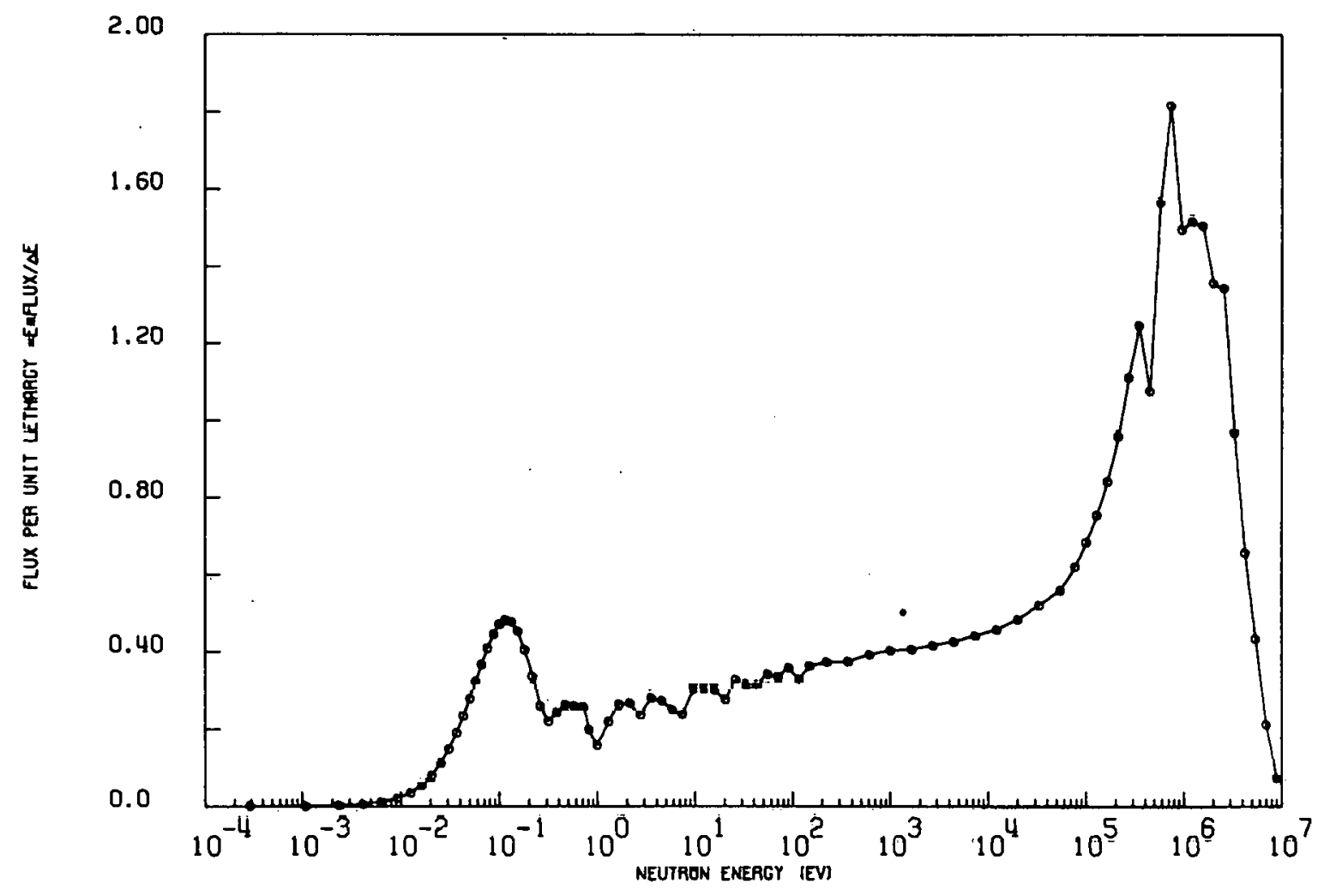

Fig. A.6. Neutron energy spectrum in a BWR-PuPu. 
Table A.1. Flux per unft lethargy for U-Pu cycle PUR and BWR 'fuels

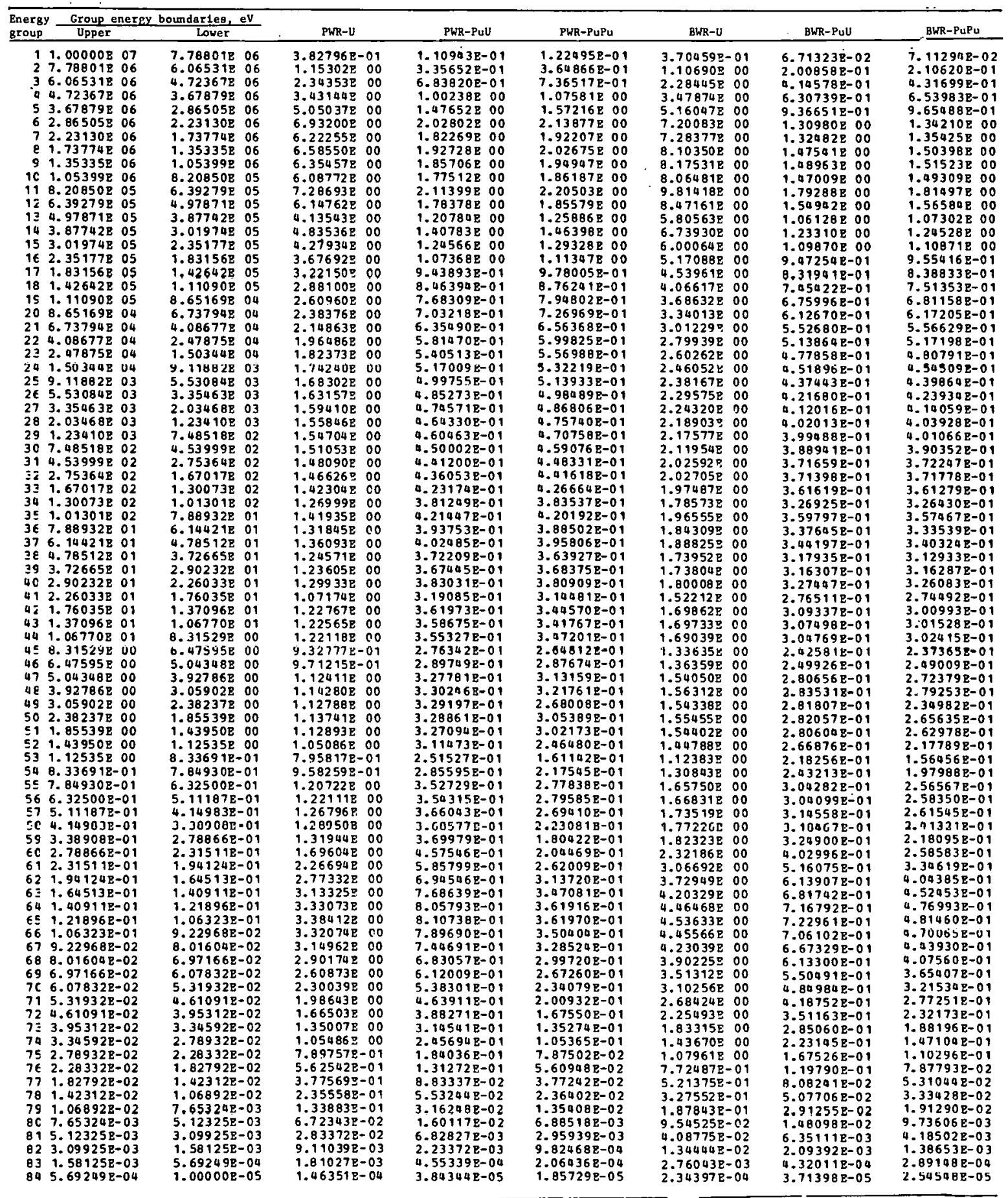


THIS PAGE

\section{WAS INTENTIONALLY}

LEFT BLANK 
APPENDIX B :

ONE-GROUP, SPECTRUM-AVERAGED CROSS SECTIONS FOR U-PU CYCLE

PWR AND BWR FUELS 
Table B.1. One-group, spectrum-averaged cross sections for $\mathrm{U}-\mathrm{Pu}$ cycle 1 ight-water reactors

\begin{tabular}{|c|c|c|c|c|c|c|c|}
\hline \multirow[b]{2}{*}{ Tsntope } & \multirow{3}{*}{$\begin{array}{c}\text { Cross } \\
\text { section } \\
\text { type }\end{array}$} & \multicolumn{6}{|c|}{ Cross section, barns } \\
\hline & & PWR-U & PWR-PuU & PWR-PuPu & BWR-U & BWR-PuU & BWR-PuPu \\
\hline $\mathrm{H}-$ & & $3.47 r-02$ & $? .899-02$ & $1.61 \mathrm{~F}-0 ?$ & $3.42 p-0 ?$ & 3. $098-0 ?$ & $2.315-02$ \\
\hline$B-10$ & $N, A$ & $4.02 E \quad 02$ & $3.35 \mathrm{E} \quad 02$ & $1.86 \mathrm{E} \quad 02$ & $3.64 P \quad 02$ & $3.28 \mathrm{E} 02$ & 2. $36 \mathrm{E} \quad 02$ \\
\hline$B-11$ & $N, G$ & $5.35 \mathrm{E}-04$ & $4.48 \mathrm{E}-04$ & $2.56 \mathrm{E}-04$ & $4.87 \mathrm{~B}-04$ & $4.418-04$ & $3.21 \mathrm{E}-04$ \\
\hline$c-12$ & $N, G$ & 3. $11 \mathrm{E}-04$ & $2.74 E-04$ & $9.44 \mathrm{~F}-04$ & $3.21 E-04$ & $2.89 \mathrm{E}-04$ & $2.07 E-04$ \\
\hline$N-14$ & $\mathrm{~N}, \mathrm{P}$ & $1.81 E-01$ & $1.62 \mathrm{E}-01$ & $9.34 \mathrm{E}-02$ & $1.85 E-01$ & $1.69 \mathrm{E}-01$ & 1. $26 F-01$ \\
\hline $0-16$ & $\mathrm{~N}, \mathrm{~A}$ & 2. $72 E-03$ & $2.75 \mathrm{E}-03$ & 3. $13 \mathrm{E}-03$ & $2.04 \mathrm{E}-03$ & $2.06 \mathrm{~B}-03$ & $2.25 \mathrm{E}-03$ \\
\hline NA -23 & $N, G$ & $5.28 \mathrm{E}-02$ & $4.73 E-02$ & $2.70 F-02$ & $5.47 \mathrm{E}-02$ & 4. $98 \mathrm{E}-02$ & $1 E-02$ \\
\hline$C R-52$ & $N, G$ & $3.35 \mathrm{E}-01$ & $2.81 \mathrm{E}-01$ & $1.62 E-01$ & $3.06 \mathrm{E}-01$ & $2.77 \mathrm{E}-01$ & $2.03 E-01$ \\
\hline$M N-55$ & $\mathrm{~N}, \mathrm{G}$ & $1.53 \mathrm{E} 00$ & $1.39 \mathrm{~B} 00$ & $9.0115-01$ & $1.57 \mathrm{E} \quad 00$ & $1.116 \mathrm{E} \quad 00$ & $1.15 \mathrm{E} 00$ \\
\hline$F E-56$ & $N, G$ & $2.68 E-01$ & $2.298-01$ & $1.31 \mathrm{E}-01$ & $2.73 E-01$ & $2.48 \mathrm{E}-01$ & $1.88 \mathrm{E}-01$ \\
\hline$N I-5 R$ & $N, G$ & $4.87 \mathrm{E}=01$ & $4.07 \mathrm{E}-01$ & $2.31 \mathrm{E}=01$ & $4.43 \mathrm{E}=01$ & $4.01 \mathrm{E}=01$ & $1 E=01$ \\
\hline$G F-72$ & $N, G$ & $1.23 \mathrm{E}-01$ & 1. $17 \mathrm{E}-01$ & $8.23 \mathrm{~F}-02$ & $1.23 E-01$ & $1.24 E-01$ & $1.02 E-01$ \\
\hline$G E-73$ & $N, G$ & $7 \mathrm{E} \quad 00$ & $3.30 \mathrm{E} \quad 00$ & $2.85 \mathrm{E} 00$ & $3.33 E 00$ & $3.44 \mathrm{E} \quad 00$ & E 00 \\
\hline$G E-74$ & $N, G$ & $1 E-02$ & $5.30 E-02$ & $4.00 \mathrm{E}-02$ & $5.56 \mathrm{E}-02$ & $5.59 \mathrm{E}-02$ & $4.79 E-02$ \\
\hline$G E=76$ & $N, G$ & $5 E-02$ & $5.76 z-02$ & $5.57 \mathrm{E}-02$ & $5.86 \mathbf{E}-02$ & $6.02 \mathrm{E}-02$ & 5. $92 \mathrm{E}-02$ \\
\hline AS -75 & $N, G$ & $2.15 \mathrm{E} \quad 00$ & $2.24 \mathrm{E} \quad 00$ & $2.16 \mathrm{~F} 00$ & $2.21 \mathrm{E} \quad 00$ & $2.31 \mathrm{E} 00$ & $2.29 E \quad 00$ \\
\hline$S E-76$ & $N, G$ & $7.88 \mathrm{E} \quad 00$ & $7.33 \mathrm{E} 00$ & $4.05 \mathrm{E} 00$ & $7.81 \mathrm{E} \quad 00$ & $7.84 \mathrm{E} 00$ & $5.81 \mathrm{E} \quad 00$ \\
\hline$S E-77$ & $N, G$ & $4.38 \mathrm{E} \quad 00$ & 4.14800 & $2.55 \mathrm{E} 00$ & $4.38 \mathrm{E} 00$ & $4.41 \mathrm{E} \quad 00$ & $3.43 E 00$ \\
\hline$S E-78$ & $N, G$ & $1.85 E-01$ & $1.90 F-01$ & $1.86 \mathrm{E}-01$ & $1.90 E-01$ & $1.95 \mathrm{E}-01$ & $E-01$ \\
\hline$S E-80$ & $\mathrm{~N}, \mathrm{G}$ & $8.99 E-02$ & $8.69 E-02$ & $6.63 \mathrm{E}-02$ & $9.10 \mathrm{E}-02$ & $9.19 \mathrm{E}-02$ & $E-02$ \\
\hline$S E-82$ & $N, G$ & $8.62 \mathrm{E}-03$ & 8. $35 \mathrm{E}-03$ & 7. $04 \mathrm{~F}, 03$ & $8.71 \mathrm{E}-03$ & $8.69 E-03$ & $7.88 E-03$ \\
\hline$B P-79$ & $N, G$ & $4.80 \mathrm{E} \quad 00$ & $4.97 \mathrm{E} \quad 00$ & $4.78 \mathrm{~F} 00$ & $4.96 \mathrm{E} 00$ & $5.16 \mathrm{~B} 00$ & $5.09 \mathrm{E} \quad 00$ \\
\hline$B R-81$ & $N, G$ & $1.79 \mathrm{E} \quad 00$ & $1.85 \mathrm{E} \quad 00$ & $1.95 \mathrm{E} 00$ & $1.85 \mathrm{E} \quad 00$ & $1.91 \mathrm{E} 00$ & 1.93800 \\
\hline$K R-80$ & $N, G$ & $2.82 E 00$ & $2.87 \mathrm{E} \quad 00$ & 2. $42 F 00$ & $2.86 E 00$ & $\begin{array}{ll}3.00 E & 00 \\
7 & \end{array}$ & $\begin{array}{ll}2.74 E & 00 \\
7.78 E & 00\end{array}$ \\
\hline $\begin{array}{l}K P-82 \\
K P-83\end{array}$ & $N, G$ & $\begin{array}{ll}25 E & 00 \\
13 E & 01\end{array}$ & $\begin{array}{l}7.44 E 00 \\
2.01 \mathrm{~F}\end{array}$ & $6.43 \mathrm{E} 00$ & $7.36 E 00$ & $7.75 \mathrm{E} 00$ & $\begin{array}{ll}7.18 \mathrm{E} & 00 \\
1.68 \mathrm{E} & 01\end{array}$ \\
\hline $\begin{array}{l}K R-83 \\
K R-84\end{array}$ & $\begin{array}{l}N, G \\
N, G\end{array}$ & $\begin{array}{rr}3 E & 01 \\
5 E-01\end{array}$ & $\begin{array}{rl}2.01 \mathrm{E} & 01 \\
1.30 \mathrm{E}-01\end{array}$ & $\begin{array}{r}1.25 \mathrm{E} \quad 01 \\
1.37 \mathrm{E}-01\end{array}$ & $\begin{array}{rr}2.13 \mathrm{E} & 01 \\
1.31 \mathrm{E}-01\end{array}$ & $\begin{array}{l}2.14 \mathrm{E} \quad 01 \\
1.35 \mathrm{E}-01\end{array}$ & $\begin{array}{l}1.68 \mathrm{E} \quad 01 \\
1.40 \mathrm{E}-01\end{array}$ \\
\hline$K R-85$ & $N, G$ & $4 E-01$ & $1.74 E-01$ & 1. $13 \mathrm{E}-01$ & $1.84 \mathrm{E}-01$ & $1.86 \mathrm{E}-01$ & $3 E-01$ \\
\hline$K B=86$ & $N, G$ & $1 \mathrm{E}=02$ & $9.838=03$ & $7.87 \mathrm{E}=03$ & $1.03 E=02$ & $1.04 \mathrm{E}=02$ & $9.18 x-03$ \\
\hline R. $9-85$ & $N, G$ & $2 E-01$ & $2.57 \mathrm{E}-01$ & $2.57 \mathrm{E}-01$ & $2.62 \mathrm{E}-01$ & $2.68 \mathrm{E}-01$ & $E-01$ \\
\hline$R B-86$ & $N, G$ & $1.14 \mathrm{E} \quad 00$ & $1.14 \mathrm{E} \quad 00$ & $1.01 \mathrm{E} 00$ & $1.16 \mathrm{~F} \quad 00$ & $1.19 \mathrm{E} 00$ & $1.11 E 00$ \\
\hline $\mathrm{RB}-87$ & $\mathrm{~N}, \mathrm{G}$ & $9 E-02$ & $7.94 \mathrm{E}-02$ & $7.97 \mathrm{E}-02$ & $7.88 \mathrm{E}-02$ & 8. $12 \mathrm{E}-02$ & $3 E-02$ \\
\hline$S R-86$ & $N, G$ & $E-01$ & $3.79 \mathrm{E}-01$ & 2. $80 \mathrm{E}-01$ & $96 \mathrm{E}-01$ & $4.01 \mathrm{E}-01$ & 3. $40 E-01$ \\
\hline$S P-87$ & $N, G$ & $O E \quad O O$ & $4.25 E \quad 00$ & $3.65 \mathrm{E} \quad 00$ & $37 \mathrm{E} 00$ & $4.44 \mathrm{EO} 00$ & $O E \quad O O$ \\
\hline$S R-8 R$ & $N, G$ & $1.24 \mathrm{E}-03$ & $1.20 \mathrm{E}-03$ & $1.05 \mathrm{E}-0 \mathrm{~J}$ & $1.23 \mathrm{E}-03$ & $1.21 \mathrm{E}-03$ & $1.11 E-03$ \\
\hline$S R-89$ & $\mathrm{~N}$ & $5.26 \mathrm{E}-02$ & $5.03 E-02$ & $3.53 \mathrm{E}-02$ & $5.28 \mathrm{E}-02$ & $5.31 \mathrm{e}-02$ & $E-02$ \\
\hline$S R-90$ & N, G & $74 E-02$ & $8.15 E-02$ & $4.72 \mathrm{E}-02$ & $8.68 E-02$ & $8.71 \mathrm{E}-02$ & $6.58 E-02$ \\
\hline $7-89$ & N, G & $3 E-01$ & $25 E_{i}-01$ & $7.72 \mathrm{E}-02$ & $3 E-01$ & $1.33 \mathrm{E}-01$ & $4 E-01$ \\
\hline$Y-90$ & $N, G$ & $3 E-01$ & 4. $15 E-01$ & $2.89 \mathrm{E}-01$ & $6 E-01$ & $4.40 \mathrm{E}-01$ & $3 E-01$ \\
\hline$Y-91$ & $N, G$ & $5 E-01$ & $1.57 F-01$ & $1.06 \mathrm{E}-01$ & $1.66 z-01$ & $1.67 \mathrm{E}-01$ & 1. $36 \mathrm{E}-01$ \\
\hline$Z R-90$ & $N, G$ & $1 E-02$ & $2.47 E-02$ & $2.23 \mathrm{E}-02$ & $2.54 \mathrm{E}-02$ & $2.55 \mathrm{E}-02$ & $2.40 \mathrm{E}-02$ \\
\hline $2 R-91$ & $\mathbf{N}, \mathbf{G}$ & -01 & $77 E-01$ & $2.52 \mathrm{E}-01$ & $1 E-01$ & $2.88 \mathrm{E}-01$ & 2 \\
\hline $28-92$ & $N, G$ & $3 E-02$ & 5. $36 z-02$ & $4.62 E-02$ & $5.56 E-02$ & $5.62 \mathrm{E}-02$ & 5. $18 E-02$ \\
\hline$Z R-92$ & $N, G$ & $O E-02$ & $5.68 \mathrm{E}-02$ & $5.19 E-02$ & $6.10 E-02$ & $5.98 E-02$ & $\mathrm{E}-02$ \\
\hline $2 R-93$ & $N, G$ & $3 \mathrm{E} \quad 00$ & $1.07 E 00$ & $1.03 \mathrm{E} 00$ & $1.06 \mathrm{E} \quad 00$ & $1.11 \mathrm{E} \quad 00$ & $1.09 E \quad 00$ \\
\hline ZR- 94 & $N, G$ & $4 E-02$ & $1.94 \mathrm{E}-02$ & $1.85 \pi-02$ & $2.01 \mathrm{E}-02$ & $2.03 \mathrm{E}-02$ & $1.98 \mathrm{E}-02$ \\
\hline$Z R-95$ & $N, G$ & $2 E-01$ & $37 \mathrm{~F}-01$ & $2.33 \mathrm{E}-01$ & $2.40 \mathrm{E}-01$ & $2.46 E-01$ & $2.45 \mathrm{E}-01$ \\
\hline $2 R=96$ & $\mathrm{~N}, \mathrm{G}$ & $7 E-01$ & $1.85 .8-01$ & $1.28 \mathrm{E}-01$ & $1.81 \mathrm{E}-01$ & $1.87 \mathrm{~B}-01$ & $1.96 \mathrm{E}-01$ \\
\hline $\mathrm{NB}-93$ & $N, G$ & $O E-01$ & $.17 \mathrm{E}-01$ & $3.96 E-01$ & $4.23 \mathrm{E}-01$ & 4. $35 \mathrm{E}-01$ & $4.24 \mathrm{E}-01$ \\
\hline
\end{tabular}


Table B.1 (continued)

\begin{tabular}{|c|c|c|c|c|c|c|c|}
\hline \multirow[b]{2}{*}{ Isotope } & $\begin{array}{l}\text { Cross } \\
\text { section }\end{array}$ & \multicolumn{6}{|c|}{ Cross section, barns } \\
\hline & type & $\overline{P W R-U}$ & PWR-PuU & PWR-PuPu & BWR-U & BWR-PuI & $\mathrm{BWR}-\mathrm{PuPu}$ \\
\hline$\overline{\mathrm{NB}-93}$ & $\mathrm{~N}, \mathrm{G}$ & $4 . \overline{32 E-01}$ & $4.23 \mathrm{E}-01$ & $4.03 \mathrm{E}-01$ & $4.32 \mathrm{E}-01$ & $4.28 \mathrm{E}-01$ & $4.17 E-01$ \\
\hline$N B-94$ & $\mathrm{~N}, \mathrm{G}$ & $4.28 \mathrm{E} \quad 00$ & $4.33 \mathrm{E} \quad 00$ & $3.86 \mathrm{E} \quad 00$ & $4.39 \mathrm{~F}, 00$ & $4.51 \mathrm{E} 00$ & $4.28 \mathrm{~F}, 00$ \\
\hline NB -95 & $N, G$ & $8.51 E-01$ & $8.75 F-01$ & $8.72 \mathrm{E}-01$ & $8.79 \mathrm{E}-01$ & $9.06 z-01$ & $9.08 E-01$ \\
\hline MO- 94 & $N, G$ & $3.95 E-02$ & 4. $065-02$ & $4.33 F-02$ & $4.11 \mathrm{E}-02$ & 4. $18 \mathrm{E}-02$ & 4. $36 E-02$ \\
\hline MO- 95 & $N, G$ & $4.22 \mathrm{E} \quad 00$ & $4.36 \mathrm{E} \quad 00$ & $3.91 \mathrm{E} 00$ & $4.30 \mathrm{E} \quad 00$ & $4.53 \mathrm{E} 00$ & $4.29 \mathrm{E} 00$ \\
\hline MO- 96 & $N, G$ & $6.87 E-01$ & 7. $12 E-01$ & $7.13 E-01$ & $7.10 \mathrm{E}-01$ & $7.35 \mathrm{E}-01$ & $7.41 E-01$ \\
\hline MO- 97 & $N, G$ & $6.93 E-01$ & $7.05 \mathrm{E}-01$ & $6.55 r-01$ & $7.14 \mathrm{E}-09$ & $7.35 \mathrm{E}-01$ & $7.08 E-01$ \\
\hline MO- 98 & N, G & $37 E-01$ & $2.46 E-01$ & $2.56 \mathrm{~F}-01$ & $2.47 \mathrm{E}-01$ & $2.54 \mathrm{E}-01$ & $2.62 \mathrm{E}-01$ \\
\hline MO- 98 & N, G & $1.14 \mathrm{E} \quad 00$ & $1.12 \mathrm{E} \quad 00$ & $1.06 \mathrm{E} 00$ & $1.12 E 00$ & $1.11 \mathrm{E} 00$ & $1.08 \mathrm{E} 00$ \\
\hline MO- 99 & N, G & $1.01 E \quad 00$ & $1.05 \mathrm{E} \quad 00$ & $1.04 \mathrm{~F} 00$ & $1.05 \mathrm{E} 00$ & $1.08 \mathrm{E} 00$ & $1.09 \mathrm{E} 00$ \\
\hline$M 0-100$ & $N, G$ & $1.48 \mathrm{E}-01$ & $1.53 \mathrm{E}-01$ & $1.55 F-01$ & $1.53 \mathrm{E}-01$ & $1.57 \mathrm{E}-01$ & $1.60 \mathrm{E}-01$ \\
\hline TC. -99 & $\mathrm{~N}, \mathrm{G}$ & $9.14 \mathrm{E} \cap 0$ & $9.83 \mathrm{E} \quad 00$ & $9.45 \mathrm{E} 00$ & $9.30 \mathrm{E} 00$ & $1.03 \mathrm{E} 01$ & $1.01 \mathrm{E} \quad 01$ \\
\hline$R U-99$ & $N, G$ & $4.31 \mathrm{E} \quad 00$ & $4.45 E \quad 00$ & $4.44 \mathrm{~F} .00$ & 4.46500 & $4.60 \mathrm{E} 00$ & $4.65 \mathrm{E} \quad 00$ \\
\hline $\mathrm{RU}-100$ & $N, G$ & $7.80 \mathrm{E}-01$ & $7.53 E-01$ & $5.48 \mathrm{E}-01$ & $7.87 \mathrm{E}-01$ & $7.96 E-01$ & $6.71 \mathrm{E}-01$ \\
\hline$R ! 1-101$ & $N, G$ & $2.95 \mathrm{E} \quad 00$ & $3.08 E 00$ & $3.04 E 00$ & $3.05 \mathrm{E} \cap 0$ & $3.18 \mathrm{E} \quad 00$ & $3.19 \mathrm{E} \quad 00$ \\
\hline$R \Pi-102$ & N, G & $2.62 \mathrm{E}-01$ & $2.58 \mathrm{E}-01$ & $2.20 \mathrm{~F}-01$ & $2.66 \mathrm{E}-01$ & $2.69 \mathrm{E}-01$ & $2.46 \mathrm{E}-01$ \\
\hline$R U-103$ & $N, G$ & $2.67 \mathrm{E} 00$ & $2.74 \mathrm{E} \quad 00$ & $2.55 \mathrm{~F}: 00$ & $2.74 \mathrm{~F} 00$ & $2.85 \mathrm{E} \quad 00$ & $2.75 \mathrm{~F} \quad 00$ \\
\hline$R U-104$ & $N, G$ & $2.62 E-01$ & $2.69 E-01$ & $2.69 \mathrm{~F}-01$ & $2.71 E-01$ & $2.78 E-01$ & $2.80 E-01$ \\
\hline $\mathrm{BU}-105$ & $N, G$ & $2.91 E-01$ & $3.00 \mathrm{E}-01$ & $3.15 \mathrm{~F}-01$ & $3.05 E-01$ & 3. $12 E-01$ & 3. $22 \mathrm{E}-01$ \\
\hline $\mathrm{RO}-106$ & $N, G$ & $90 E-02$ & 9. $10 E-02$ & $9.19 \mathrm{E}-02$ & $9.29 E-02$ & $9.51 E-02$ & $9.59 E-02$ \\
\hline RH -103 & $\mathrm{~N}, \mathrm{G}$ & $3.68 \mathrm{E} 01$ & $3.75 \% 01$ & $2.69 \mathrm{E} 01$ & $3.71 \mathrm{~F} 01$ & $3.93 \mathrm{E} \quad 01$ & $3.17 \mathrm{~F} \quad 01$ \\
\hline $\mathrm{BH}-105$ & $N, G$ & $1.02 E \quad 03$ & $9.80 \mathrm{~F} \quad 02$ & $5.97 \mathrm{~F} \quad 02$ & 1.01503 & $1.04 E 03$ & $7.98 \mathrm{E} \quad 02$ \\
\hline PD -104 & $N, G$ & $6.46 \mathrm{E}-01$ & $6.71 \mathrm{E}-01$ & $7.02 \mathrm{E}-01$ & $6.70 \mathrm{E}-01$ & $6.89 \mathrm{E}-01$ & 7. $12 \mathrm{E}-01$ \\
\hline$P D-105$ & $N, G$ & $3.83 \mathrm{E} \quad 00$ & $3.85 \mathrm{E} \quad 00$ & $3.42 . \mathrm{E} 00$ & $3.92 F 0$ & $4.02 \mathrm{E} \quad 00$ & $3.79 F \quad 00$ \\
\hline$P D-106$ & $N, G$ & $75 E-01$ & $2.84 E-01$ & $2.95 E-01$ & $83 E-01$ & $2.91 \mathrm{E}-01$ & $99 E-01$ \\
\hline$P D-107$ & $N, G$ & $2.82 \mathrm{E} \quad 00$ & $2.87 E \quad 00$ & $2.59 \mathrm{~F}, 00$ & $2.88 \div 00$ & $2.99 \mathrm{E} \quad 00$ & $2.84 E 00$ \\
\hline$P D-108$ & N, G & $7.09 \mathrm{E} \quad 00$ & $7.42 \mathrm{E} \quad 00$ & $7.29 \mathrm{~F} \quad 00$ & $7.35 \% 00$ & $7.70 \mathrm{E} \quad 00$ & $7.70 E 00$ \\
\hline PD -110 & N, G & $2.59 \mathrm{E}-01$ & $2.69 \mathrm{E}-01$ & 2. $80 \mathrm{~F}-01$ & $2.70 \mathrm{~F}-01$ & $2.78 \mathrm{E}-01$ & $2.86 \mathrm{E}-01$ \\
\hline$A G-107$ & $N, G$ & $6.25 \mathrm{E} \quad 00$ & $6.16 \mathrm{E} \quad 00$ & $4.83 \mathrm{E} 00$ & $6.33 E 00$ & $6.47 \mathrm{E} \quad 00$ & $5.68 \mathrm{E} 00$ \\
\hline$A G-100$ & $N, G$ & $39 E \quad 01$ & 4. $12 \mathrm{E} 01$ & $3.88 \mathrm{E} 01$ & $3.95 \mathrm{~F} 01$ & $4.29 E \quad 01$ & $4.19 \mathrm{~F} \quad 01$ \\
\hline$A G-111$ & $N, G$ & $3.46 \mathrm{E} \quad 00$ & $3.61 \mathrm{E} \quad 00$ & $3.70 \mathrm{E} \quad 00$ & $3.59 \mathrm{E} \quad 00$ & $3.73 \mathrm{E} 00$ & $3.81 \mathrm{E} 00$ \\
\hline$C D-109$ & $N, G$ & $2.64 \mathrm{E}-01$ & 2. $62 E-01$ & $2.34 \mathrm{E}-01$ & $2.69 E-01$ & $2.71 \mathrm{E}-01$ & $2.54 \mathrm{E}-01$ \\
\hline$C D-110$ & $N, G$ & $2.24 \mathrm{E} 00$ & $2.21 E 00$ & $1.85 \mathrm{E} 00$ & $2.28 \mathrm{E} \quad 00$ & $2.31 \mathrm{E} \quad 00$ & $2.10 \mathrm{E} \quad 00$ \\
\hline$C D-111$ & $N, G$ & $3.55 \mathrm{E} O 0$ & $3.468 \quad 00$ & $2.60 \mathrm{E} 00$ & $3.59 \mathrm{E} 00$ & $3.64 \mathrm{E} 00$ & $3.13 \mathrm{E} \quad 00$ \\
\hline$C D-112$ & $N, G$ & $33 E-01$ & $6.41 \mathrm{E}-01$ & $5.84 E-01$ & $.49 \mathrm{E}-01$ & $6.66 E-01$ & $6.34 E-01$ \\
\hline$C D-113$ & $N, G$ & $04 \mathrm{E} \quad 03$ & $3.67 \mathrm{E} .03$ & $1.73 \mathrm{E} \quad 03$ & $3.99 \nabla 03$ & $3.93 \mathrm{E} \quad 03$ & $2.73 \mathrm{~F}, 03$ \\
\hline$C D-114$ & $N, G$ & $6.45 E-01$ & $6.83 B-01$ & $7.16 E-01$ & $6.68 \mathrm{E}-01$ & $7.03 E-01$ & $7.28 \mathrm{E}-01$ \\
\hline$C D-115$ & $N, G$ & $8.22 \mathrm{E} \quad 00$ & $8.35 \mathrm{E} 00$ & $7.46 \mathrm{E} \quad 00$ & $3.42 \mathrm{~F} 00$ & $8.70 \mathrm{E} \quad 00$ & $8.21 E 00$ \\
\hline$C D-116$ & $N, G$ & $1.05 \mathrm{E}-01$ & $1.07 \mathrm{E}-01$ & 1. $13 \varepsilon-01$ & $1.098-01$ & $1.11 E-01$ & $1.1 \& F-01$ \\
\hline IN -113 & $N, G$ & $7.03 \mathrm{E} \quad 00$ & $7.22 \mathrm{E} \quad 00$ & $6.85 \mathrm{~F} 00$ & $7.22 \mathrm{E} \quad 00$ & $7.47 \mathrm{E} \quad 00$ & $7.31 \mathrm{~F} \quad 00$ \\
\hline IN -115 & $N, G$ & $61 \mathrm{E} \quad 01$ & $9.78 \mathrm{E} \quad 01$ & $8.21 \mathrm{~F} 01$ & $9.79 \mathrm{~F} 01$ & $1.02 \mathrm{E} \quad 02$ & $9.02 \mathrm{E} 01$ \\
\hline$S N-115$ & $N, G$ & $55 \mathrm{E} \quad 00$ & $4.23 \mathrm{E} \quad 00$ & 2. $29 \mathrm{E} 00$ & $4.51 \mathrm{~F} \quad 00$ & $4.53 E \quad 00$ & $3.33 \mathrm{E} \quad 00$ \\
\hline$S N-116$ & $N, G$ & $3.45 E-01$ & $3.74 \mathrm{I}-01$ & 3. $92 \mathrm{E}-01$ & $3.57 \mathrm{E}-01$ & $3.85 E-01$ & $4.00 E-01$ \\
\hline$S N-117$ & $N, G$ & $62 E-01$ & $7.80 E-01$ & $7.09 \mathrm{~F}-01$ & $7.90 \mathrm{E}-01$ & 8. $12 E-01$ & $7.73 E-01$ \\
\hline$S N-118$ & $N, G$ & $2.27 E-01$ & 2. $36 E-01$ & $2.49 \mathrm{E}-01$ & $2.33 E-01$ & $2.40 E-01$ & $2.50 E-01$ \\
\hline $5 N-119$ & $N, G$ & $02 E-01$ & $2.92 F-01$ & $2.10 E-01$ & $3.04 E-01$ & $3.09 E-01$ & 2. $59 E-01$ \\
\hline $\mathrm{SN}-119$ & $N, G$ & $09 E-01$ & $1.03 \mathrm{E}-01$ & $9.26 \mathrm{E}-02$ & $1.15 E-01$ & $1.10 E-01$ & $9.78 \mathrm{E}-02$ \\
\hline$S N-120$ & $N, G$ & $87 E-02$ & $5.95 E-02$ & $5.79 E-02$ & $6.04 \mathrm{E}-02$ & $6.14 E-02$ & $6.06 E-02$ \\
\hline$S N-122$ & $N, G$ & $.22 E-02$ & 4. $22 \mathrm{E}-02$ & $3.73 E-02$ & $4.29 \mathrm{E}-02$ & 4. $39 \mathrm{E}-02$ & 4. $10 E-02$ \\
\hline$S N-123$ & $N, G$ & $.08 \mathrm{E}-01$ & 1. $12 \mathrm{E}-01$ & $1.20 \mathrm{E}-01$ & $1.13 \mathrm{E}-01$ & $1.15 E-01$ & $1.20 E-01$ \\
\hline
\end{tabular}


Table R.1 (rontitnued)

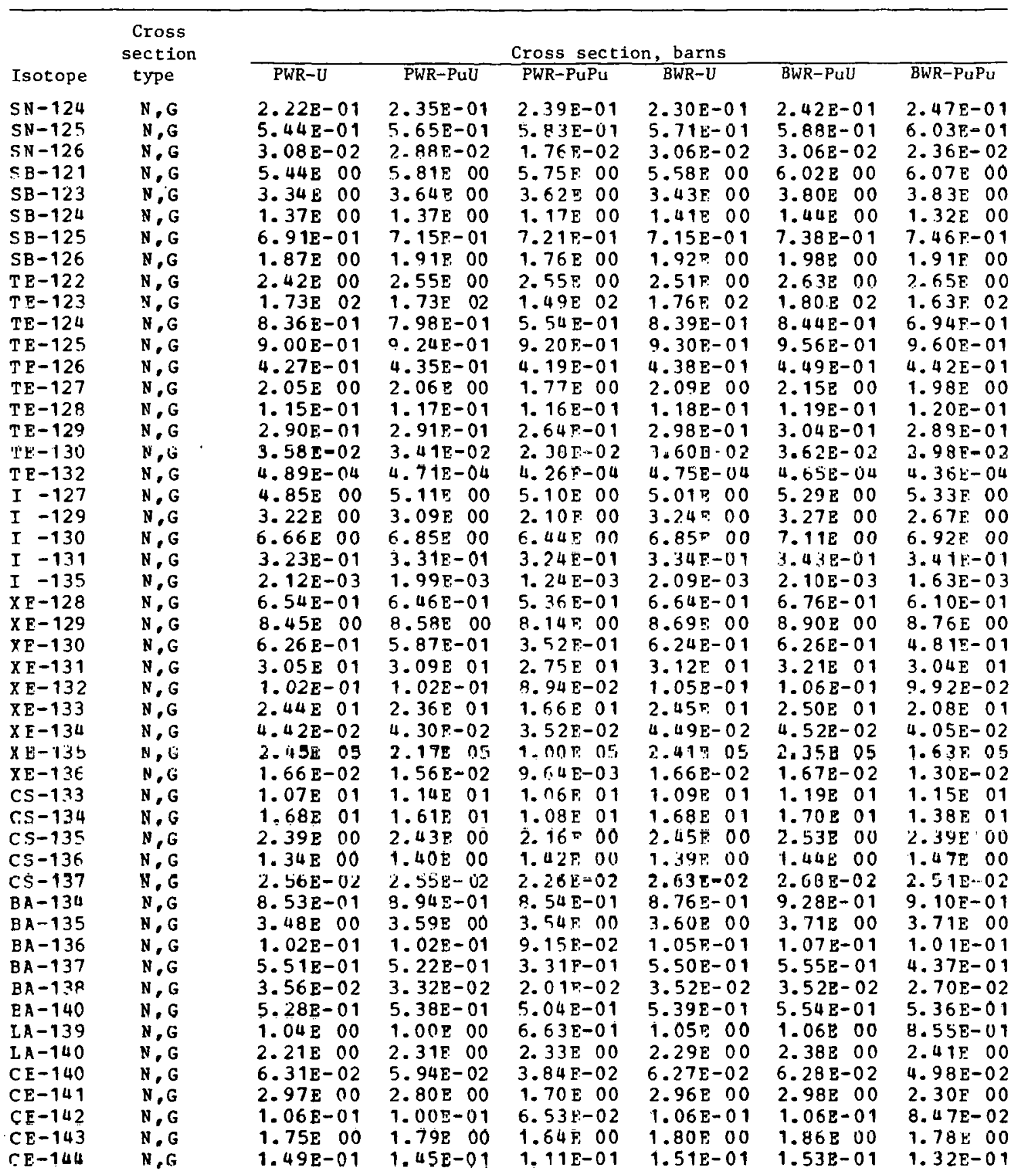


Table B.1 (continued)

\begin{tabular}{|c|c|c|c|c|c|c|c|c|c|c|}
\hline \multirow{3}{*}{$\frac{\text { Isotope }}{P R-141}$} & \multirow{3}{*}{$\begin{array}{c}\text { Cross } \\
\text { section } \\
\text { type }\end{array}$} & \multicolumn{9}{|c|}{ Cross section, barns } \\
\hline & & \multicolumn{2}{|c|}{ PWR-U } & PWR-PUU & PWR-PuPu & \multicolumn{2}{|c|}{ BWR-U } & BWR-PuU & \multicolumn{2}{|c|}{ BWR-PuPu } \\
\hline & & $1.51 \mathrm{E}$ & 00 & $1.45 \mathrm{E \quad 00}$ & $1.04 \mathrm{E} 00$ & $1.51 \mathrm{E}$ & 00 & 1.53800 & $1.28 \mathrm{E}$ & 00 \\
\hline$P R-142$ & $N, G$ & $5.59 \mathrm{E}$ & 00 & $5.71 \mathrm{E} \quad 00$ & $5.13 \mathrm{E} 00$ & $5.72 \mathrm{E}$ & 00 & $5.96 \mathrm{E} \quad 00$ & $5.65 \mathrm{E}$ & 00 \\
\hline$P R-143$ & $N, G$ & $1.21 \mathrm{E}$ & 01 & 1. 18F 01 & $8.61 \mathrm{E} 00$ & $1.22 \mathrm{E}$ & 01 & $1.25 \mathrm{E} \quad 01$ & $1.06 \mathrm{E}$ & 01 \\
\hline ND -142 & N, G & $1.71 \mathrm{E}$ & 00 & $1.59 \mathrm{E} 00$ & $8.65 \mathrm{E}-01$ & $1.69 \mathrm{E}$ & 00 & $1.70 \mathrm{E} \quad 00$ & $1.25 E$ & 00 \\
\hline N D -143 & $N, G$ & $2.87 \mathrm{E}$ & 01 & $2.65 \mathrm{E} \quad 01$ & $1.43 E .01$ & $2.84 \mathrm{E}$ & 01 & $2.84 \mathrm{E} \quad 01$ & $2.09 \mathrm{E}$ & 01 \\
\hline ND- 144 & $N, G$ & $4.71 \mathrm{E}$ & -01 & $4.54 E-01$ & $3.26 F-01$ & $4.73 \mathrm{E}$ & -01 & 4. $78 \mathrm{E}-01$ & $3.99 \mathrm{E}-$ & -01 \\
\hline ND-145 & $N, G$ & $9.35 \mathrm{E}$ & 00 & $9.35 \mathrm{E} \quad 00$ & $7.86 \mathrm{E} \quad 00$ & $9.48 E$ & 00 & $9.77 \mathrm{~B} \quad 00$ & $8.91 \mathrm{E}$ & 00 \\
\hline ND -146 & $N, G$ & $2.39 \mathrm{E}$ & -01 & 2. $33 E_{1}-01$ & $1.89 \mathrm{E}-01$ & $2.41 E$ & -01 & $2.44 \mathrm{~B}-01$ & $2.16 \mathrm{E}-$ & -01 \\
\hline NO $0-147$ & $N, G$ & $2.01 \mathrm{E}$ & 01 & $2.09 E \quad 01$ & $1.96 \mathrm{E} \quad 01$ & $2.05 \pi$ & 01 & 2.18801 & $2.12 \mathrm{E}$ & 01 \\
\hline$N D-148$ & $N, G$ & $8.67 \mathrm{E}$ & -01 & 8. $80 F-01$ & 8. $30 \mathrm{E}-01$ & 8. $96 \mathrm{E}$ & -01 & $9.08 \mathrm{E}-01$ & $8.81 \mathrm{E}-$ & -01 \\
\hline ND -150 & $N, G$ & $6.43 \mathrm{E}$ & -01 & 6. $62 \mathrm{E}-01$ & $6.50 E-01$ & $6.65 \mathrm{E}$ & -01 & $6.85 E-01$ & $6.82 \mathrm{E}-$ & -01 \\
\hline$P M-147$ & $N, G$ & $6.19 E$ & 01 & $6.61 \mathrm{E} \quad 01$ & $6.13 \mathrm{E} 01$ & $6.28 \mathrm{E}$ & 01 & $6.90 \mathrm{E} \quad 01$ & $6.69 \mathrm{E}$ & 01 \\
\hline$P M-148$ & $N, G$ & $1.17 \mathrm{E}$ & 03 & $1.22 \mathrm{E} .03$ & $9.65 \mathrm{E} 02$ & $1.19 \mathrm{E}$ & 03 & $1.27 \mathrm{E} \quad 03$ & $1.09 \mathrm{E}$ & 0.3 \\
\hline $\mathrm{PM}-148$ & $\mathrm{~N}, \mathrm{G}$ & $2.92 \mathrm{E}$ & 03 & $2.65 \mathrm{E} 03$ & $1.29 \mathrm{E} 03$ & $2.89 \mathrm{E}$ & 03 & $2.84 \mathrm{E} \quad 03$ & $1.99 \mathrm{~F}$ & 03 \\
\hline PM - 149 & $N, G$ & 1. $32 \mathrm{E}$ & 02 & $1.24 \mathrm{E} \quad 02$ & $7.00 \mathrm{E} 01$ & 1. $32 \mathrm{E}$ & 02 & 1. $32 \mathrm{E} \quad 02$ & $9.90 \mathrm{E}$ & 01 \\
\hline $\mathrm{PM}-151$ & $N, G$ & $1.03 \mathrm{E}$ & 02 & $1.01 \mathrm{E} \quad 02$ & $7.41 \mathrm{E} \quad 01$ & $1.04 \mathrm{E}$ & 02 & $1.07 \mathrm{E} \quad 02$ & $9.07 \mathrm{E}$ & 01 \\
\hline$S M-147$ & $N, G$ & $2.39 \mathrm{E}$ & 01 & 2. $48 \mathrm{E} 01$ & 2. $32 \mathrm{~F} \quad 01$ & $2.45 \mathrm{E}$ & 01 & $2.58 E \quad 01$ & $2.51 \mathrm{E}$ & 01 \\
\hline$S M-148$ & $N, G$ & 1. $14 \mathrm{E}$ & 00 & $1.16 \mathrm{E} \quad 00$ & $1.12 \mathrm{E} 00$ & $1.17 \mathrm{E}$ & 00 & $1.20 \mathrm{E} 00$ & $1.18 \%$ & 00 \\
\hline$S M-149$ & $N, G$ & $7.28 \mathrm{E}$ & 03 & $6.44 \mathrm{E} \quad 03$ & 3.025 .03 & $7.19 \mathrm{E}$ & 03 & $6.94 \mathrm{E} \quad 03$ & $4.84 \mathrm{E}$ & 03 \\
\hline$S H-150$ & $N, G$ & 1. $53 \mathrm{E}$ & 01 & $1.54 \mathrm{E} \quad 01$ & $1.19 \mathrm{E} 01$ & $1.54 \mathrm{E}$ & 01 & $1.63 \mathrm{E} \quad 01$ & $1.42 \mathrm{~F}$ & 01 \\
\hline$S M-151$ & $N, G$ & $7.26 E$ & 02 & $6.75 \mathrm{E} \quad 02$ & $3.49 \mathrm{E} 02$ & $7.16 \mathrm{E}$ & 02 & $7.30 \mathrm{E} 02$ & $5.27 \mathrm{E}$ & 02 \\
\hline$S M-152$ & $N, G$ & $7.56 \mathrm{E}$ & 01 & 8. $22 \mathrm{E} \quad 01$ & 7. 49F: 01 & $7.67 \mathrm{E}$ & 01 & $8.67 \mathrm{E} \quad 01$ & $8.34 \mathrm{E}$ & 01 \\
\hline$S M-153$ & $N, G$ & $8.98 \mathrm{E}$ & 01 & $9.34 \mathrm{E} \quad 01$ & $8.24 \mathrm{E} 01$ & $9.11 \mathrm{E}$ & 01 & $9.78 E \quad 01$ & $9.23 \mathrm{E}$ & 01 \\
\hline$S M-154$ & $N, G$ & 1. $52 \mathrm{E}$ & 00 & $1.52 \mathrm{E} \quad 00$ & $1.37 \mathrm{~F}, 00$ & 1.568 & 00 & $1.59 \mathrm{E} 00$ & $1.50 \mathrm{E}$ & 00 \\
\hline FU -151 & N, G & $7.41 \mathrm{E}$ & 02 & $7.11 \mathrm{E} \quad 02$ & 4. $09 \mathrm{E} 02$ & $7.36 \mathrm{E}$ & 02 & $7.58 \mathrm{E} \quad 02$ & $5.71 \mathrm{E}$ & 02 \\
\hline$E U-152$ & $N, G$ & $1.91 \mathrm{E}$ & 02 & $1.89 \mathrm{E} \quad 02$ & 1. $28 \mathrm{~F} .02$ & 1.925 & 02 & $2.00 \mathrm{~B} \quad 02$ & $1.61 \mathrm{E}$ & 02 \\
\hline$E U-154$ & $N, G$ & 1. $29 \mathrm{E}$ & 02 & $1.27 \mathrm{E} \quad 02$ & $8.85 \mathrm{E} 01$ & $1.29 \mathrm{E}$ & 02 & $1.34 \mathrm{E} \quad 02$ & $1.10 \mathrm{~F}$ & 02 \\
\hline EU-15. & $N, G$ & 3. $66 F$ & $n 2$ & . . $39 \mathrm{~F} \quad 02$ & 1. $82 \mathrm{~F}, 02$ & $3.62 \mathrm{E}$ & 02 & $3.63 \mathrm{E} \quad 02$ & $2.66 \mathrm{E}$ & 02 \\
\hline FO -156 & $N, G$ & $7.38 \mathrm{E}$ & 01 & $7.23 R 01$ & $5.28 \mathrm{E}, 01$ & $7.42 \mathrm{E}$ & 01 & $7.62 \mathrm{E} \quad 01$ & $6.43 \mathrm{~F}$ & 01 \\
\hline$E U-157$ & $N, G$ & $4.61 \mathrm{E}$ & 01 & $4.64 \mathrm{E} \quad 01$ & $3.84 \mathrm{E} \quad 01$ & $4.67 \mathrm{E}$ & 01 & $4.85 \mathrm{E} \quad 01$ & $4.37 \mathrm{E}$ & 01 \\
\hline GD-154 & $N, G$ & $35 \mathrm{E}$ & 01 & 1.33 E 01 & $1.04 \mathrm{E} 01$ & $1.36 \mathrm{E}$ & 01 & $1.41 \mathrm{E} \quad 01$ & $1.23 \mathrm{~F}$ & 01 \\
\hline GD-155 & $N, G$ & $2.76 \mathrm{E}$ & 03 & $2.48 \mathrm{~F}, 03$ & 1. $1.5 \mathrm{E} 03$ & $2.71 \mathrm{E}$ & 03 & $2.69 \mathrm{E} \quad 03$ & $1.88 \mathrm{E}$ & 03 \\
\hline$G D-156$ & $N, G$ & $3.77 \mathrm{E}$ & 00 & $4.00 \mathrm{E} \quad 00$ & $4.18 \mathrm{E} 00$ & $3.93 \mathrm{~F}$ & 00 & $4.13 \mathrm{E} 00$ & $4.29 \mathrm{E}$ & 00 \\
\hline G D-157 & $N, G$ & 1. $17 \mathrm{E}$ & 04 & $1.05 \mathrm{E} 04$ & $4.82 F 03$ & $1.15 \mathrm{E}$ & 04 & $1.14 \mathrm{E} \quad 04$ & $7.91 \mathrm{E}$ & 03 \\
\hline GD-159 & $N, G$ & 1. $79 \mathrm{E}$ & 00 & $1.93 \mathrm{E} \quad 00$ & $1.92 \mathrm{E} 00$ & $1.85 \mathrm{E}$ & 00 & $2.00 \mathrm{E} \quad 00$ & $2.02 \mathrm{E}$ & 00 \\
\hline$G D-160$ & $N, G$ & $3.70 \mathrm{E}$ & -01 & $3.77 \Xi-01$ & 3. $72 \mathrm{E}-01$ & $3.82 \mathrm{E}$ & -01 & $3.90 \mathrm{E}-01$ & $3.88 \mathrm{E}-$ & -01 \\
\hline$T B-159$ & $N, G$ & $1.48 \mathrm{E}$ & 01 & $1.53 \mathrm{~F} \quad 01$ & $1.47 \mathrm{EO} 01$ & $1.53 \mathrm{E}$ & 01 & $1.58 \mathrm{E} \quad 01$ & $1.57 \mathrm{E}$ & 01 \\
\hline$T B-160$ & $N, G$ & $6.86 \mathrm{E}$ & 01 & $6.63 \mathrm{E} \quad 01$ & $4.56 \mathrm{E} 01$ & $6.98 F$ & 01 & $7.02 \mathrm{E} \quad 01$ & $5.74 \mathrm{~F}$ & 01 \\
\hline DY - 160 & $N, G$ & $4.94 E$ & 01 & $5.10 \mathrm{E} \quad 01$ & $4.95 \mathrm{E} 01$ & $5.08 \mathrm{E}$ & 01 & $5.28 E \quad 01$ & $5.24 E$ & 01 \\
\hline$D Y-161$ & $N, G$ & $7.62 \mathrm{E}$ & 01 & $7.35 \mathrm{E} 01$ & $5.23 \mathrm{E} 01$ & $6 \mathrm{E}$ & 01 & $7.77 \mathrm{E} \quad 01$ & $6.47 \mathrm{E}$ & 01 \\
\hline DY -162 & $N, G$ & $7.45 \mathrm{E}$ & 01 & $7.95 \mathrm{E} \quad 01$ & $7.41 \mathrm{~F} 01$ & $56 \mathrm{E}$ & 01 & $8.29 \mathrm{E} \quad 01$ & $8.05 F$ & 01 \\
\hline DY -163 & $N, G$ & $4.82 \mathrm{E}$ & 01 & $4.83 \mathrm{~F} \quad 01$ & $4.22 \mathrm{E} 01$ & $4.91 \mathrm{E}$ & 01 & $5.03 E \quad 01$ & $4.64 \mathrm{E}$ & 01 \\
\hline D.Y -164 & $N, G$ & $1.94 \mathrm{E}$ & 02 & $1.77 \mathrm{E} \quad 02$ & $8.64 \mathrm{~F} 01$ & $1.91 \mathrm{E}$ & 02 & $1.91 \mathrm{E} \quad 02$ & $1.35 \mathrm{E}$ & 02 \\
\hline HO-165 & $N, G$ & $55 \mathrm{E}$ & 01 & $2.59 \mathrm{E} \quad 01$ & 2. $39 \mathrm{~F} \quad 01$ & $2.61 \mathrm{E}$ & 01 & $2.70 \mathrm{E} \quad 01$ & $2.60 \mathrm{~F}$ & 01 \\
\hline$E R-166$ & $N, G$ & $74 \mathrm{E}$ & 00 & $6.70 \mathrm{E} \quad 00$ & $5.45 \mathrm{~F} 00$ & $6.85 \mathrm{E}$ & 00 & $7.01 \mathrm{E} 00$ & $6.28 \mathrm{E}$ & 00 \\
\hline$E R-167$ & $N, G$ & $2.13 \mathrm{E}$ & 02 & $2.15 \mathrm{E} 02$ & 1. $54 \mathrm{E} 02$ & $2.15 \mathrm{E}$ & 02 & $2.25 E \quad 02$ & $1.87 \mathrm{E}$ & 02 \\
\hline $\mathrm{T} H-232$ & $N, G$ & $3.05 \mathrm{E}$ & 00 & $3.08 ? 00$ & $2.93 \mathrm{E} 00$ & $3.20 \mathrm{E}$ & 00 & $3.17 \mathrm{E} \quad 00$ & $3.11 \mathrm{E}$ & 00 \\
\hline TH -232 & $N, F$ & $2.22 \mathrm{E}$ & -02 & $2.24 \mathrm{E}-02$ & $2.51 \mathrm{E}-02$ & $1.79 \mathrm{~B}$ & -02 & $1.81 \mathrm{~B}-02$ & $1.96 \mathrm{E}-$ & -02 \\
\hline$P A-233$ & $N, G$ & 1. $23 \mathrm{E}$ & 01 & $1.24 \mathrm{E} 01$ & 1. $13 \mathrm{~F} .01$ & $1.28 \mathrm{E}$ & 01 & $1.28 \mathrm{E} \quad 01$ & $1.20 \mathrm{E}$ & 01 \\
\hline PA -233 & $\mathbf{N}, \mathbf{F}$ & $1.46 \mathrm{E}$ & -01 & $1.47 \mathrm{E}-01$ & $1.65 \mathrm{E}-01$ & $1.19 \mathrm{E}$ & -01 & $1.20 E-01$ & $1.30 \mathrm{E}-$ & -01 \\
\hline
\end{tabular}


Table B.l (continued)

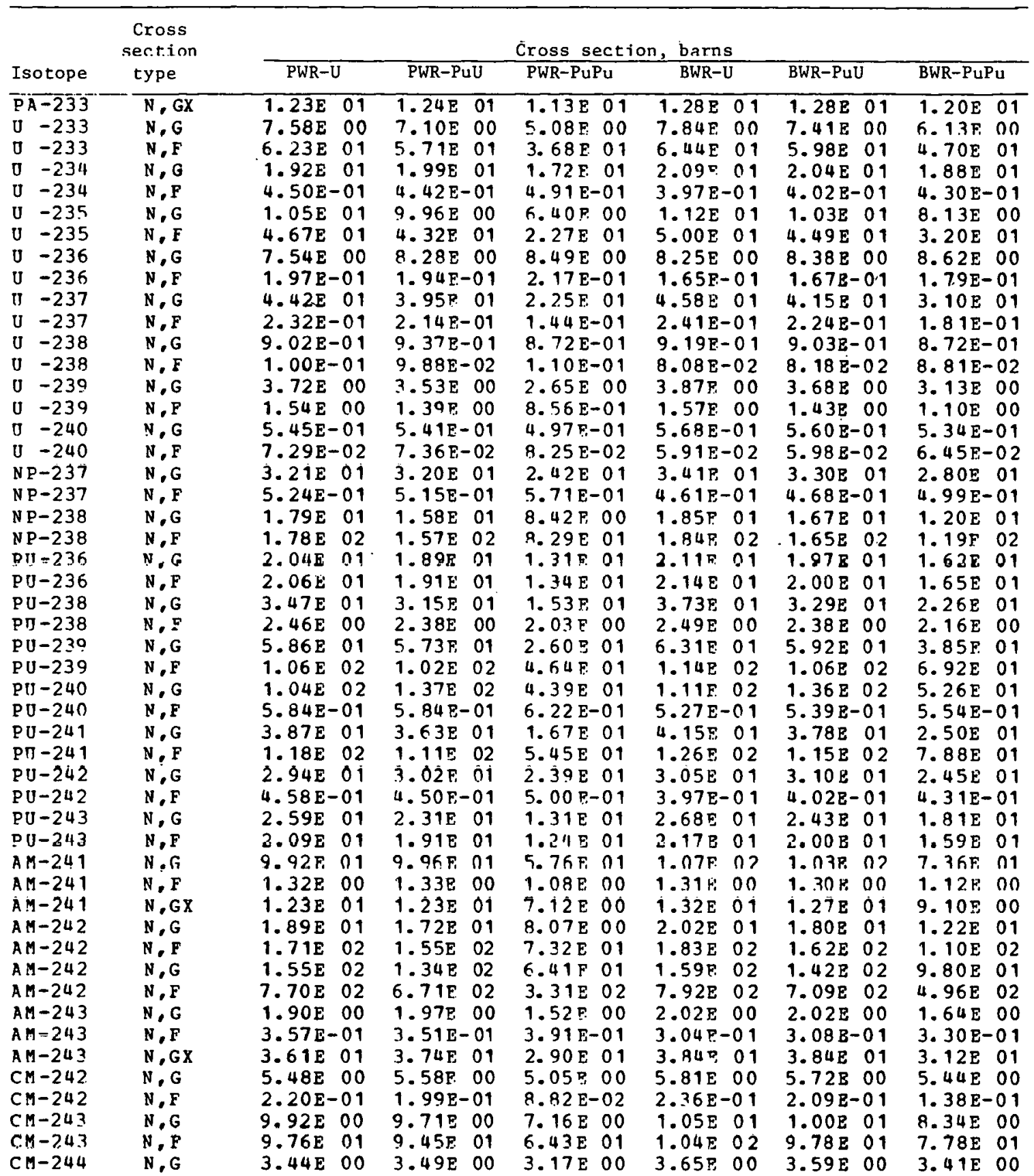


Table B.1 (continued)

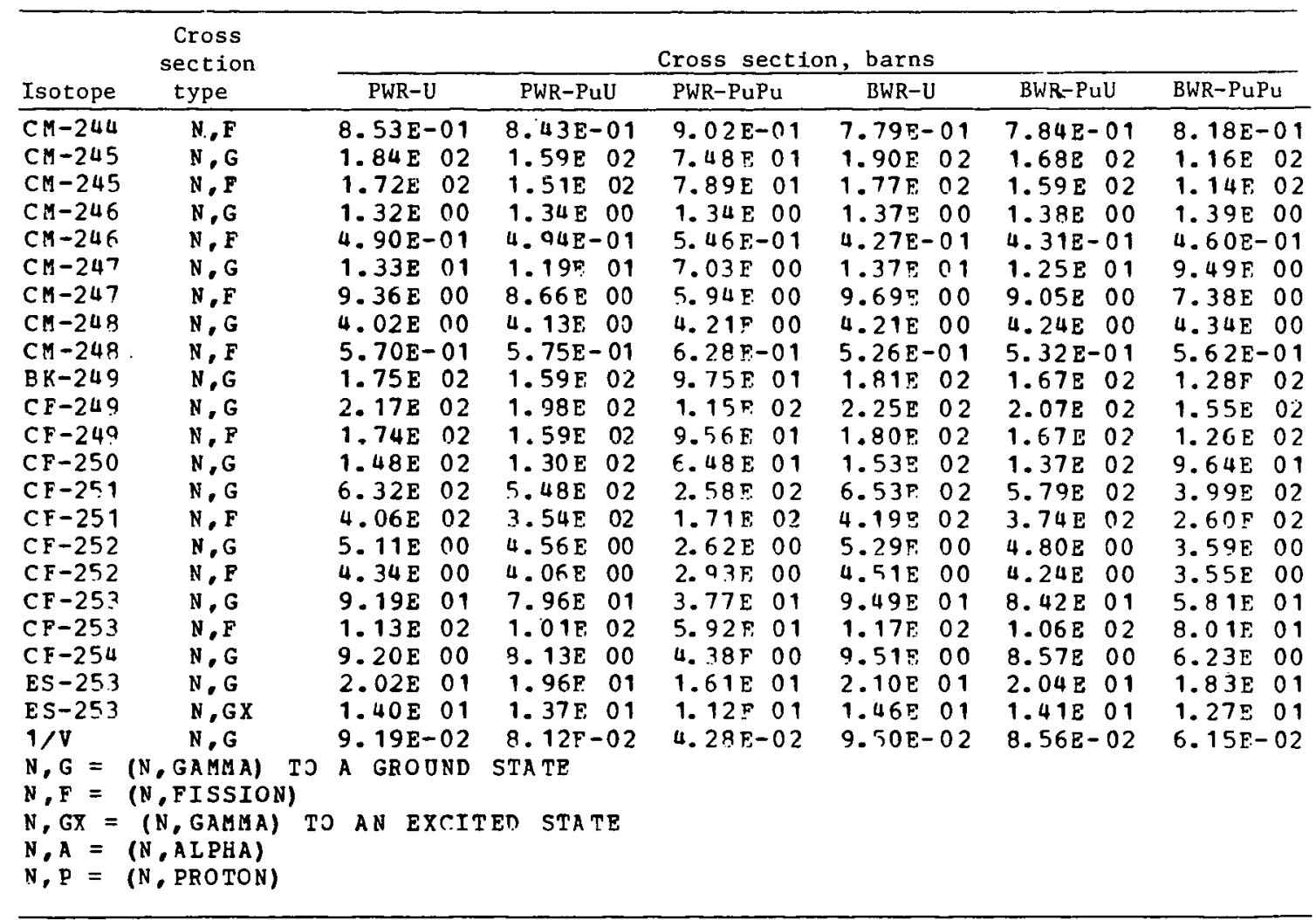


THIS PAGE

WAS INTENTIONALLY

LEFT BLANK 
APPENDIX C:

PLOTS AND LISTINGS OF SELECTED BURNUP-DEPENDENT CROSS SECTIONS FOR ORIGEN 


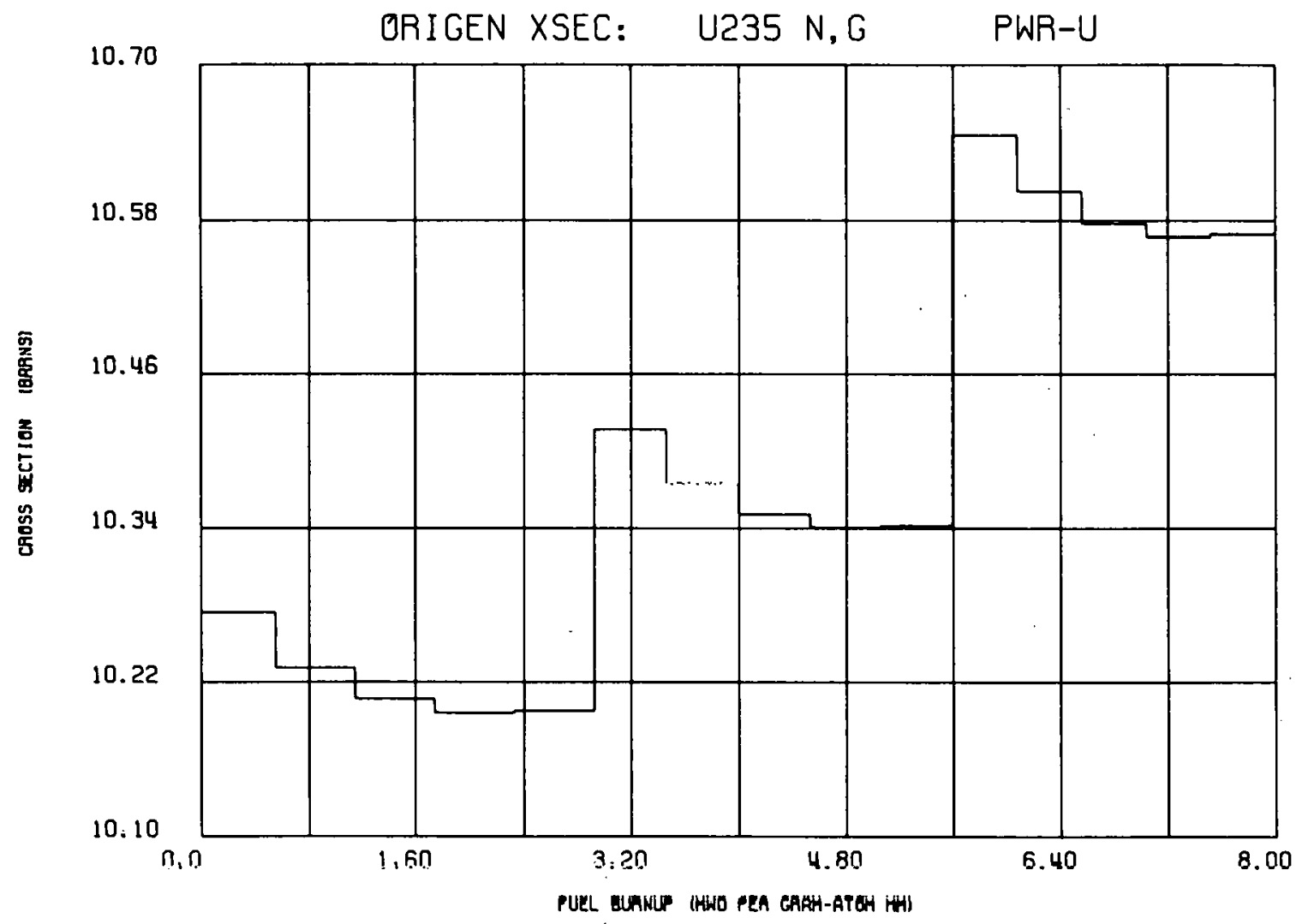

Fig. C.1. Burnup-dependent cross section of ${ }^{235} U(n, \gamma)$ reaction for PWR-U fuel. 


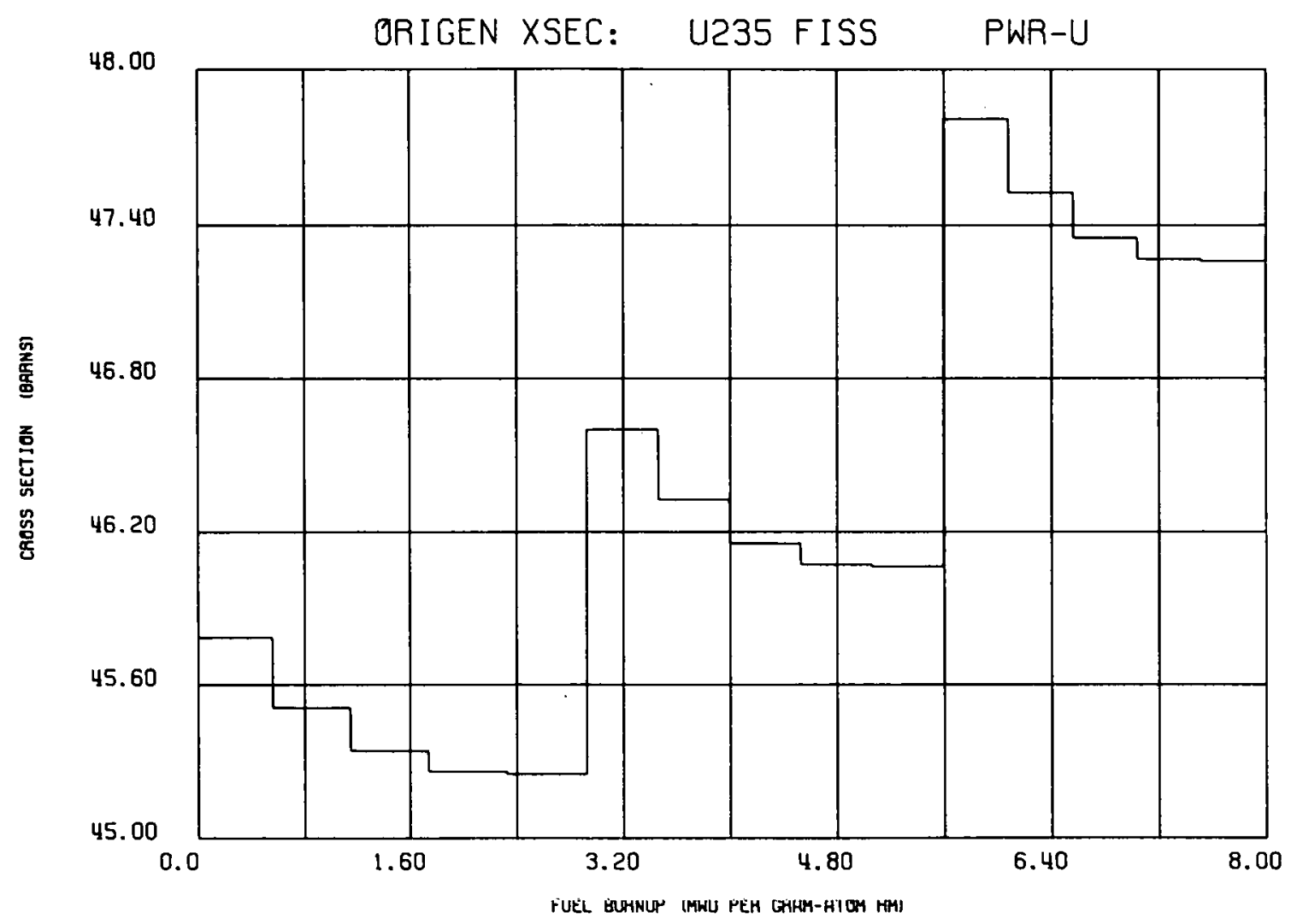

Fig. C.2. Burnup-dependent cross section of ${ }^{235} U$ (n,fission) reaction for PWR-U fuel. 


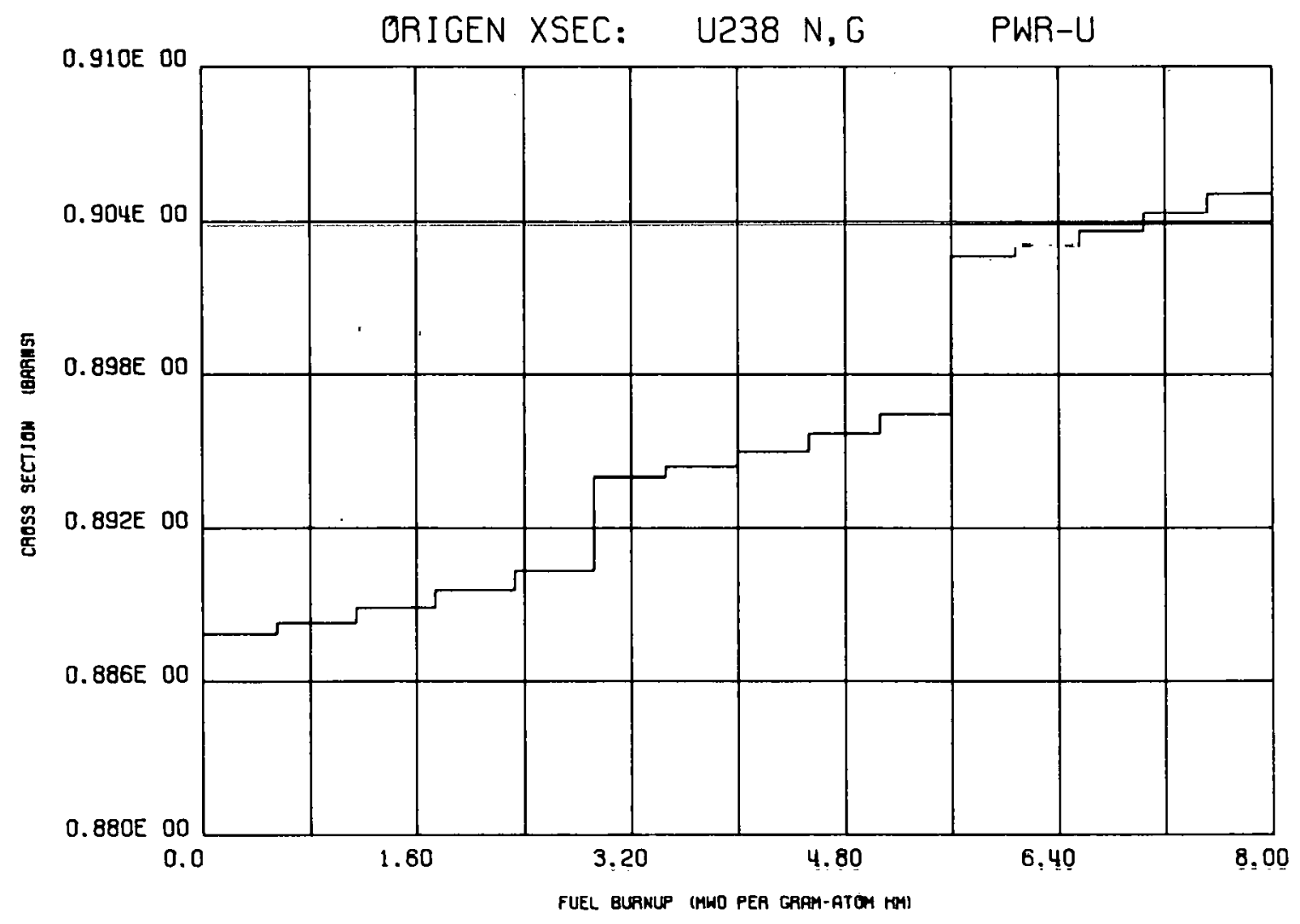

Fig. C.3. Burnup-dependent cross section of ${ }^{238} \mathrm{U}(\mathrm{n}, \gamma)$ reaction for PWR-U fuel. 


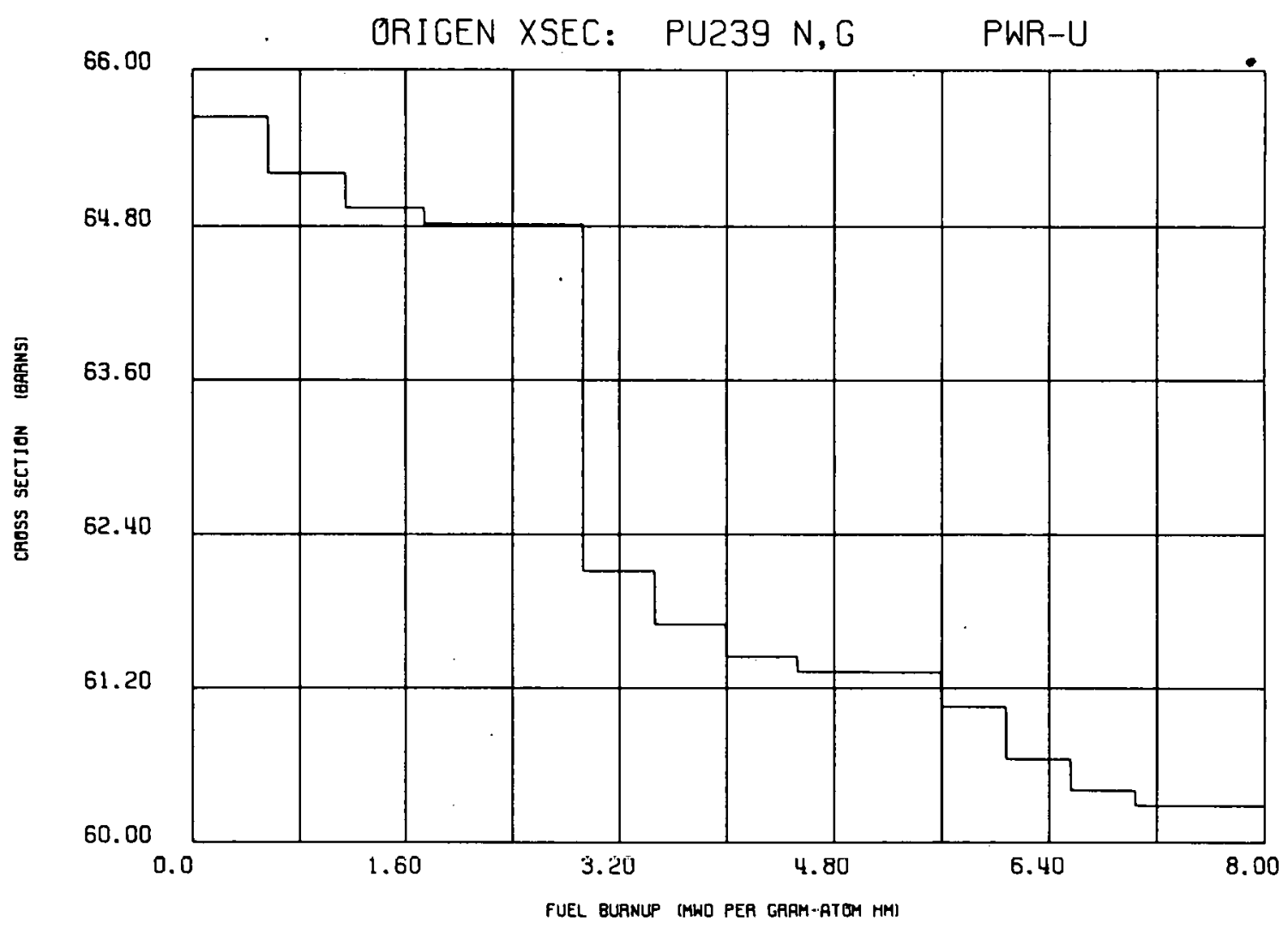

Fig. C.4. Burnup-dependent cross section of ${ }^{239} \mathrm{Pu}(n, \gamma)$ reaction for PWR-U fuel. 


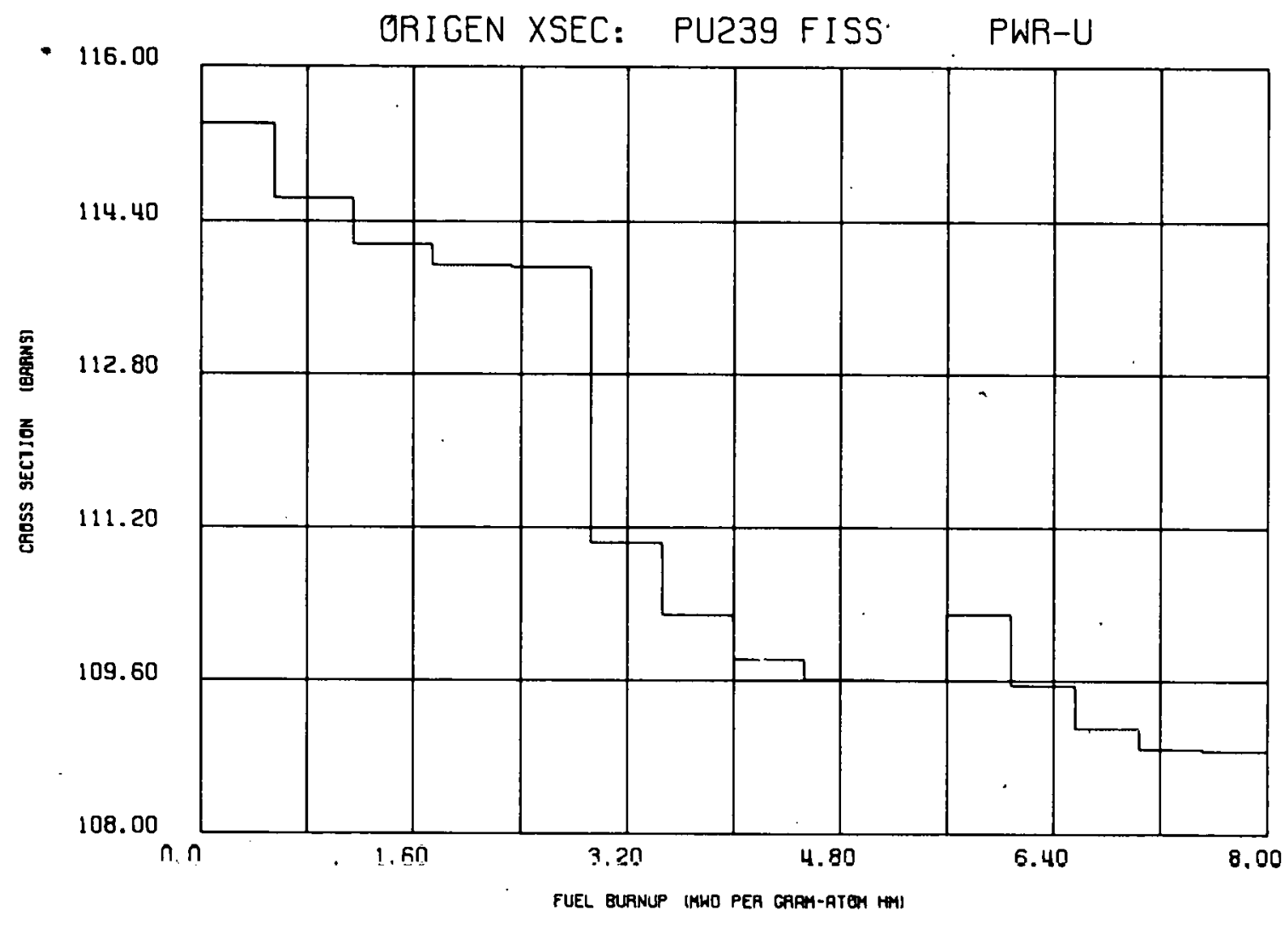

Fig. C.5. Burnup-dependent cross section of ${ }^{239} \mathrm{Pu}$ (n,fission) reaction for PWR-U fuel. 


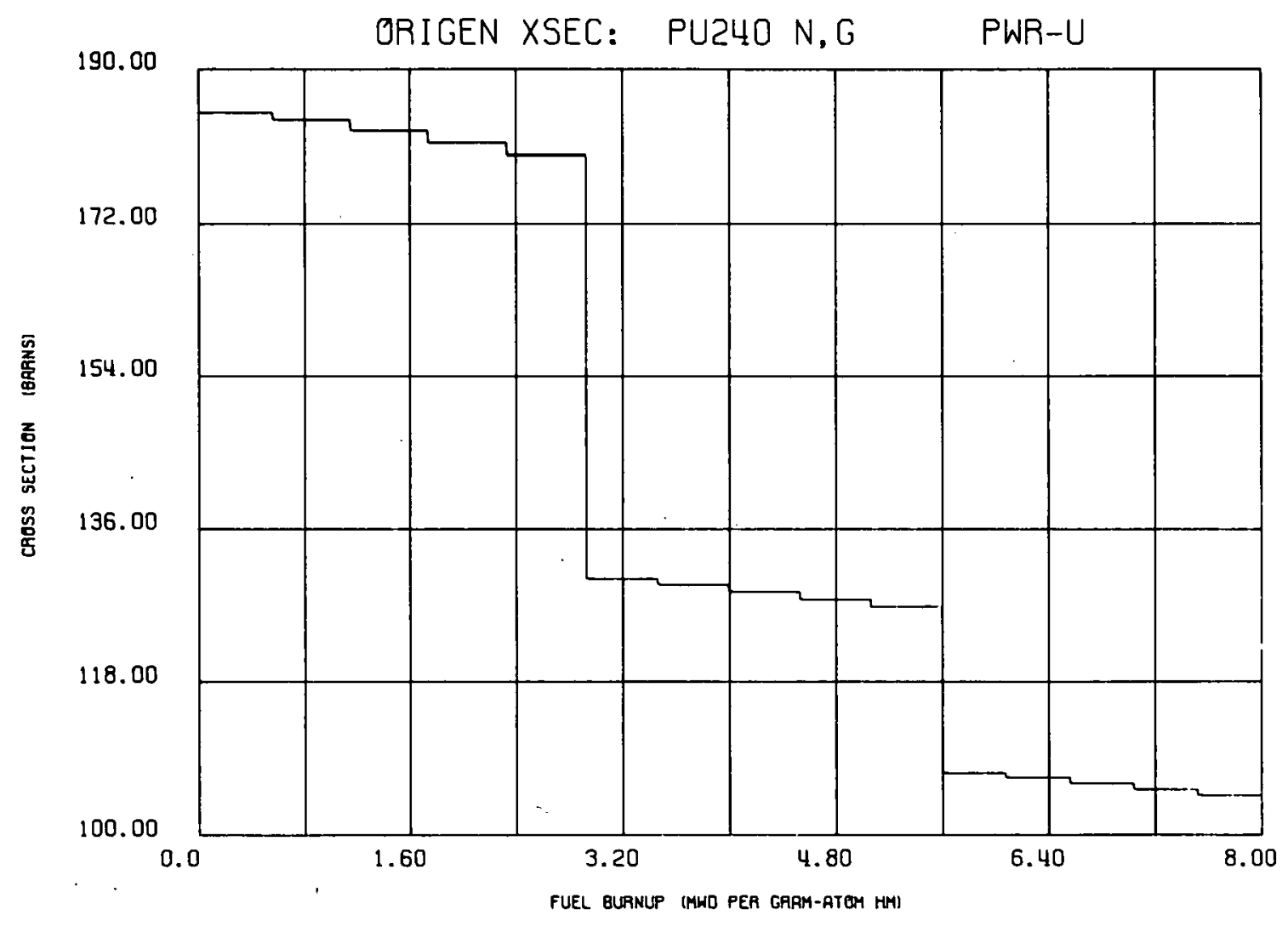

Fig. C.6. Burnup-dependent cross section of ${ }^{210} \mathrm{Pu}(n, \gamma)$ reaction for PWR-U fuel. 


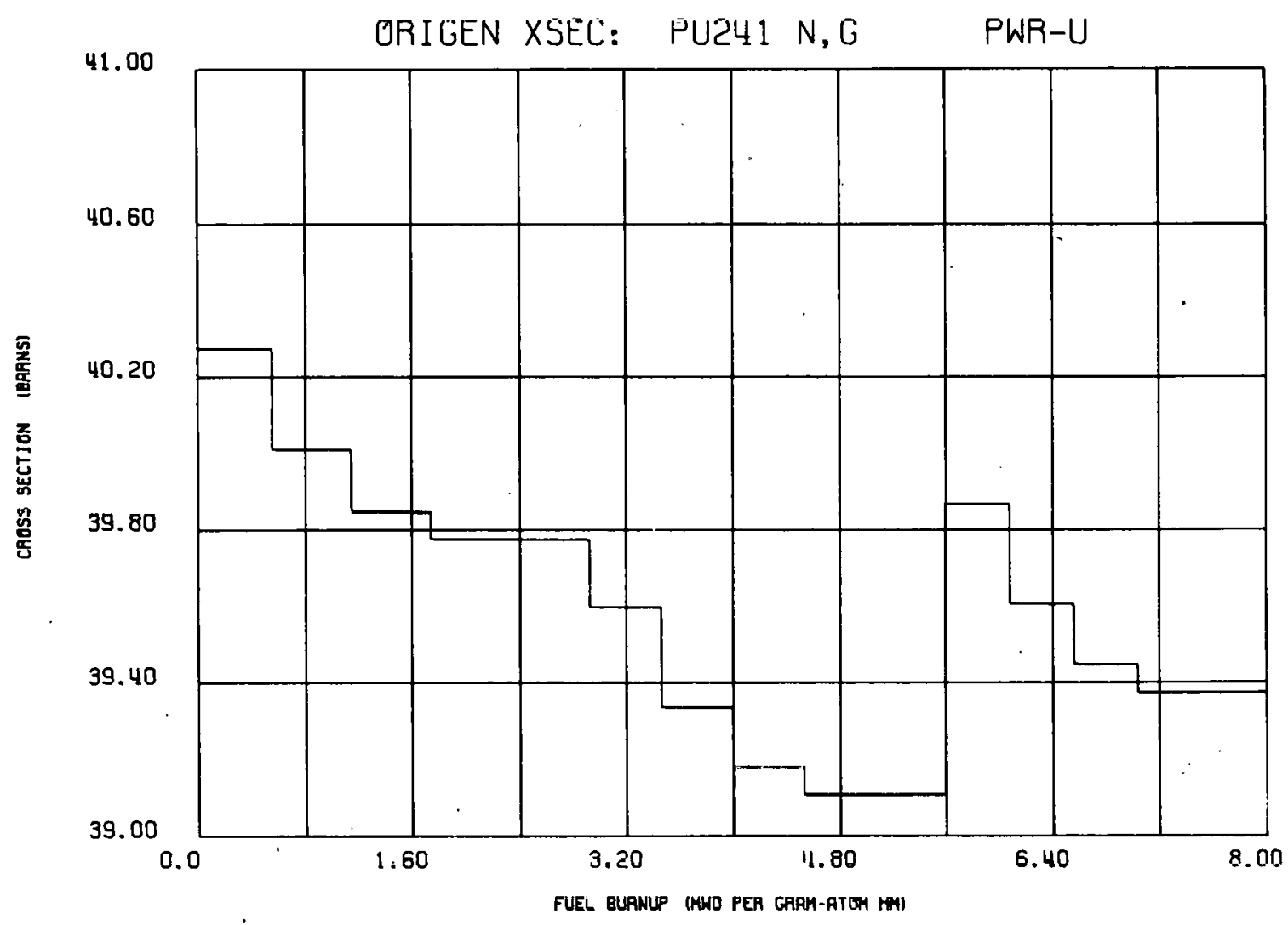

Fig. C.7. Burnup-dependent cross section of ${ }^{241} \mathrm{Pu}(n, \gamma)$ reaction for PWR-U fuel. 


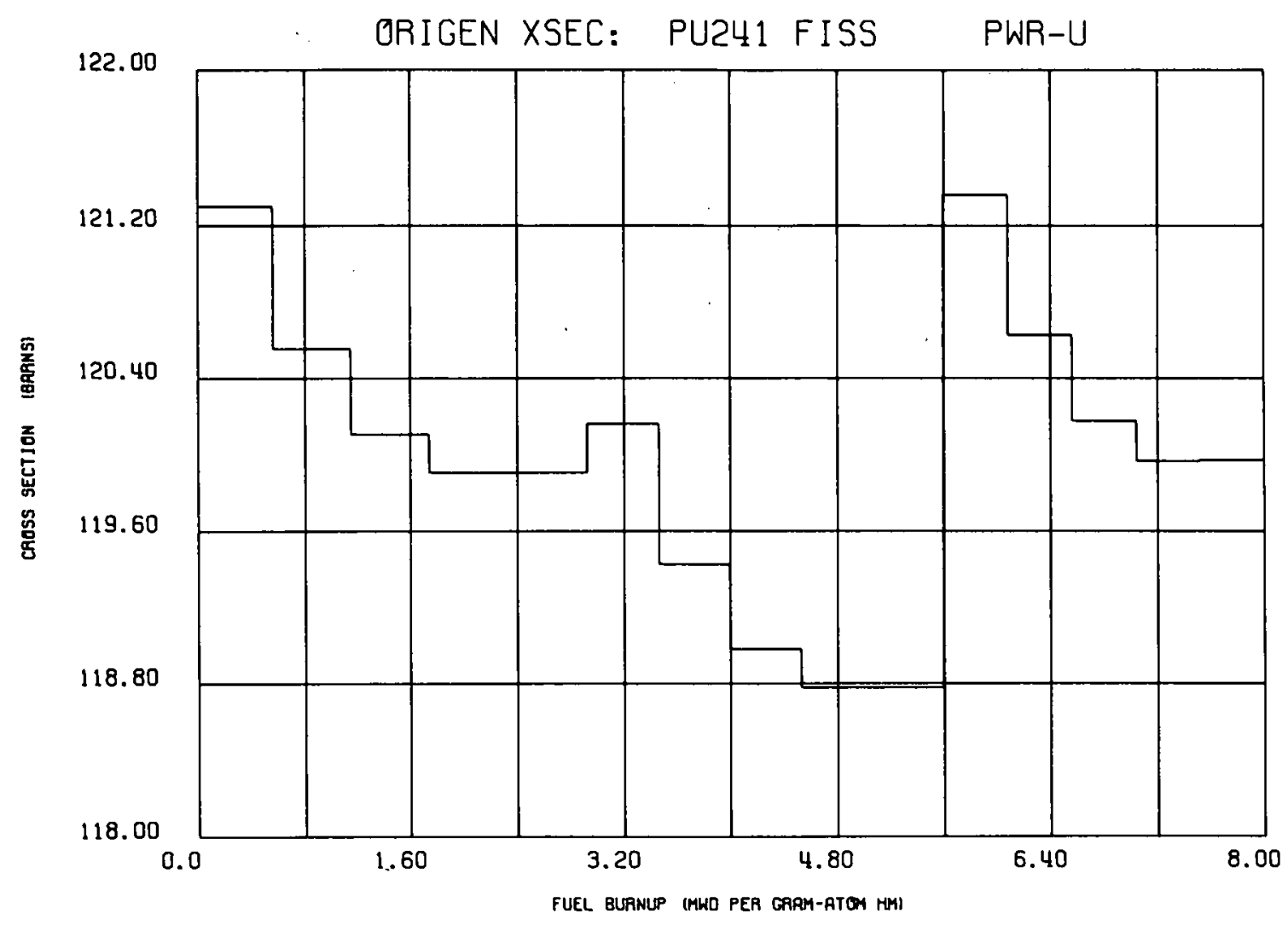

Fig. C.8. Burnup-dependent cross section of ${ }^{241} \mathrm{Pu}$ (n,fission) reartion for PWR-U fuel. 


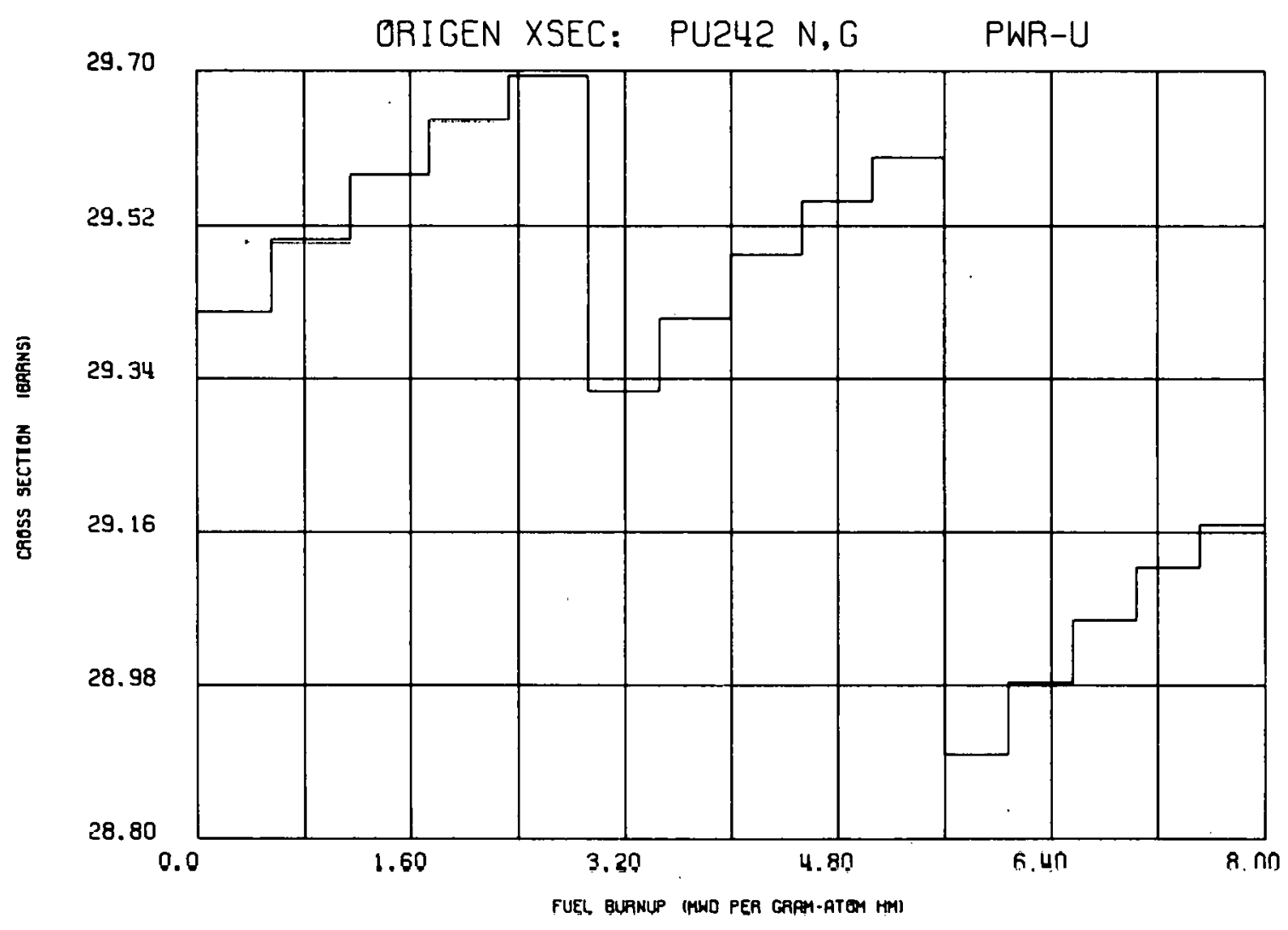

Fig. C.9. Burnup-dependent cross section of ${ }^{242} \mathrm{Pu}(n, \gamma)$ reaction for PWR-U fuel. 


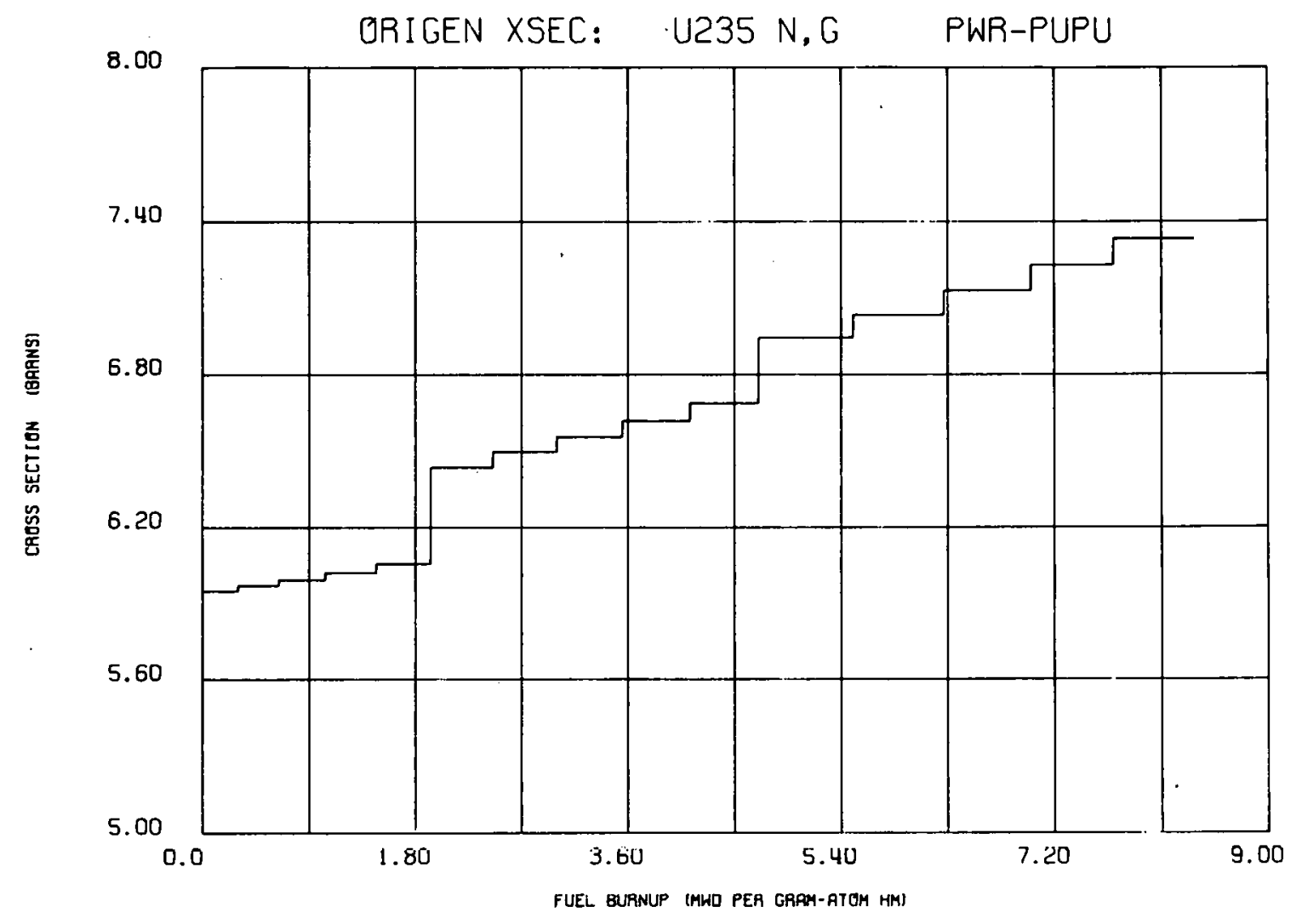

Fig. C.10. Burnup-dependent cross section of ${ }^{235} U(n, \gamma)$ reaction for PWR-PuPu fuel. 


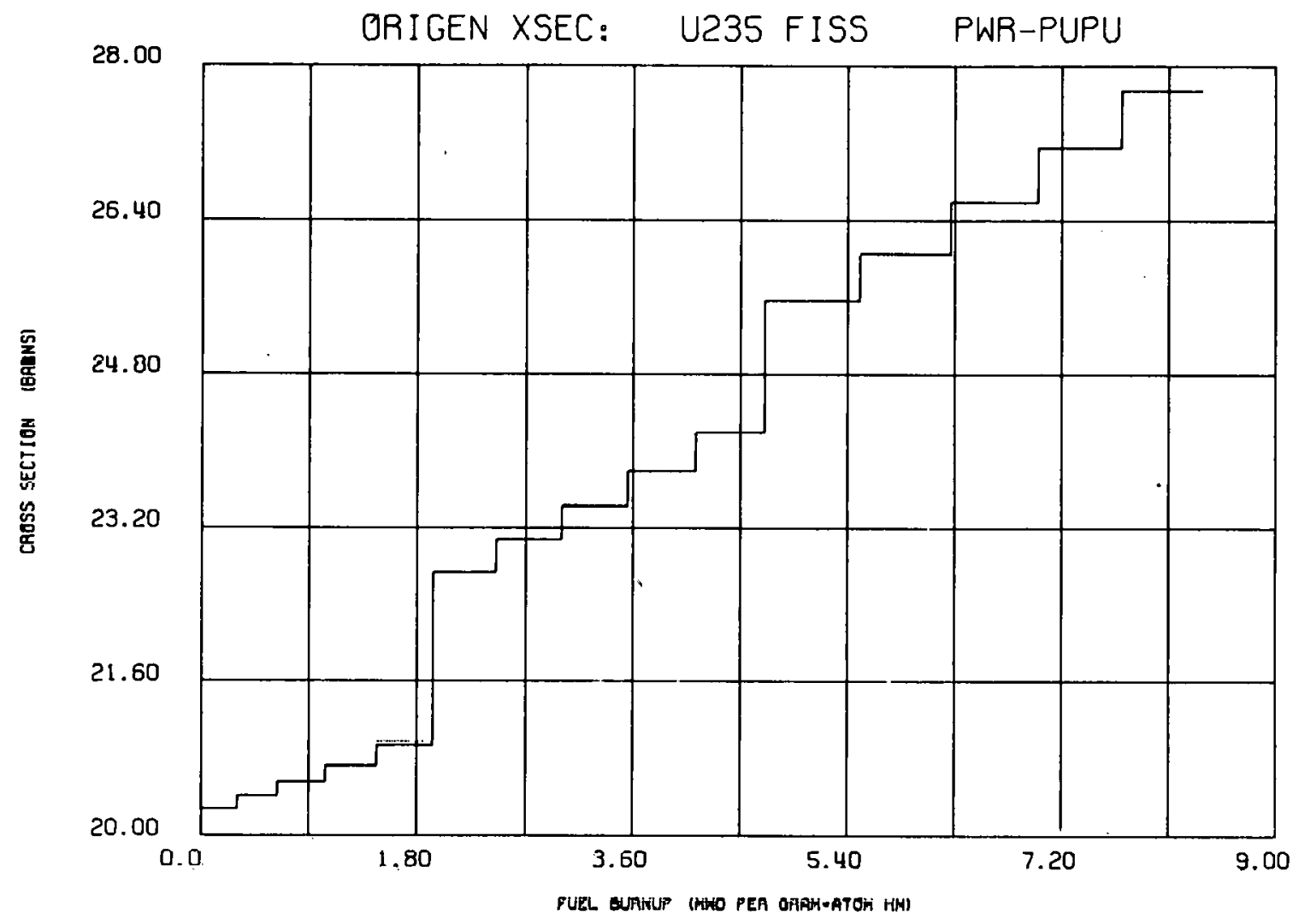

Fig. C.11. Burnup-dependent cross section of ${ }^{235} \mathrm{U}$ (n,fission) reaction for PWR-PuPu fuel. 


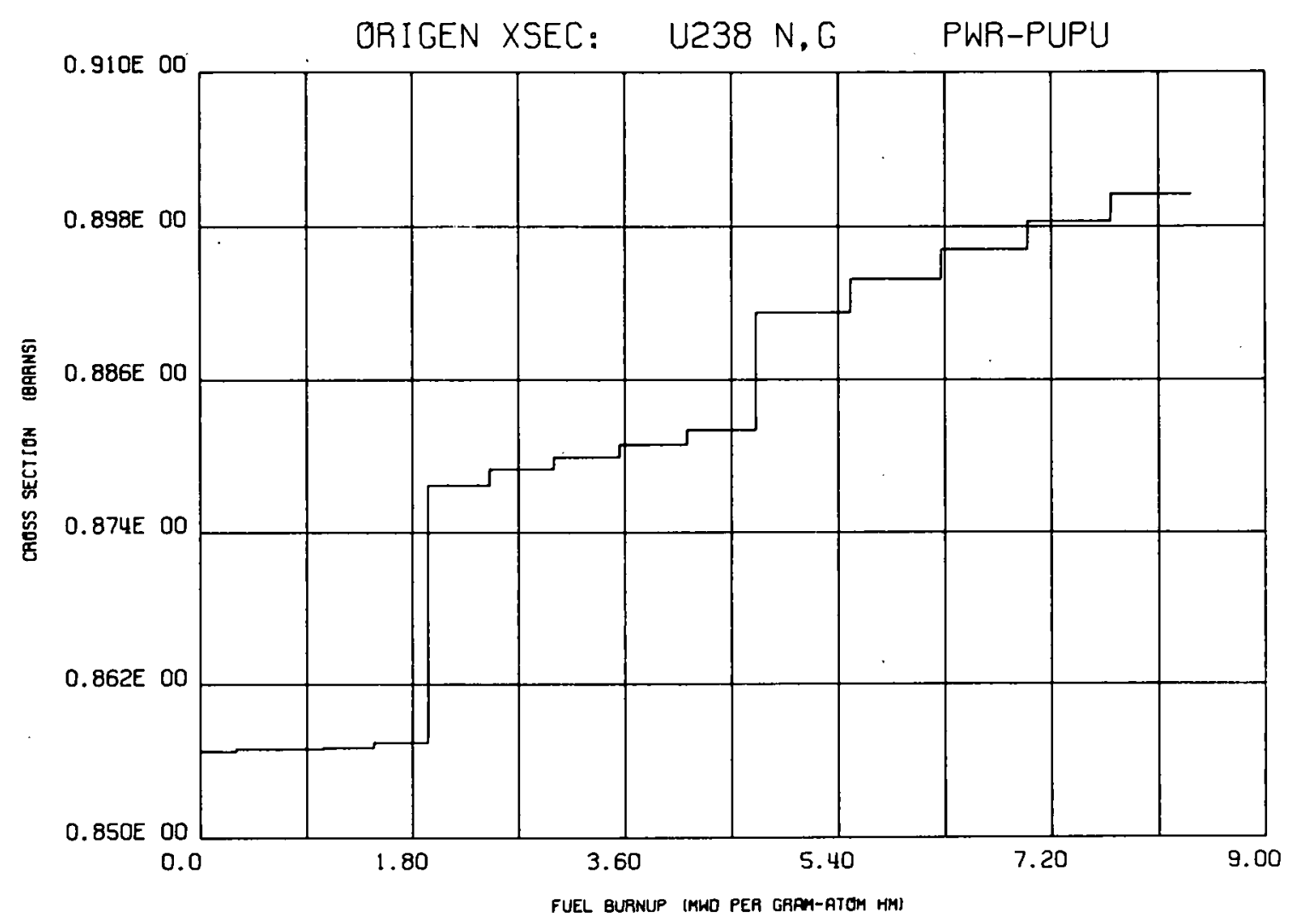

Fig. C.12. Burnup-dependent cross section of ${ }^{238} \mathrm{U}(n, \gamma)$ reaction for PWR-PuPu fucl. 


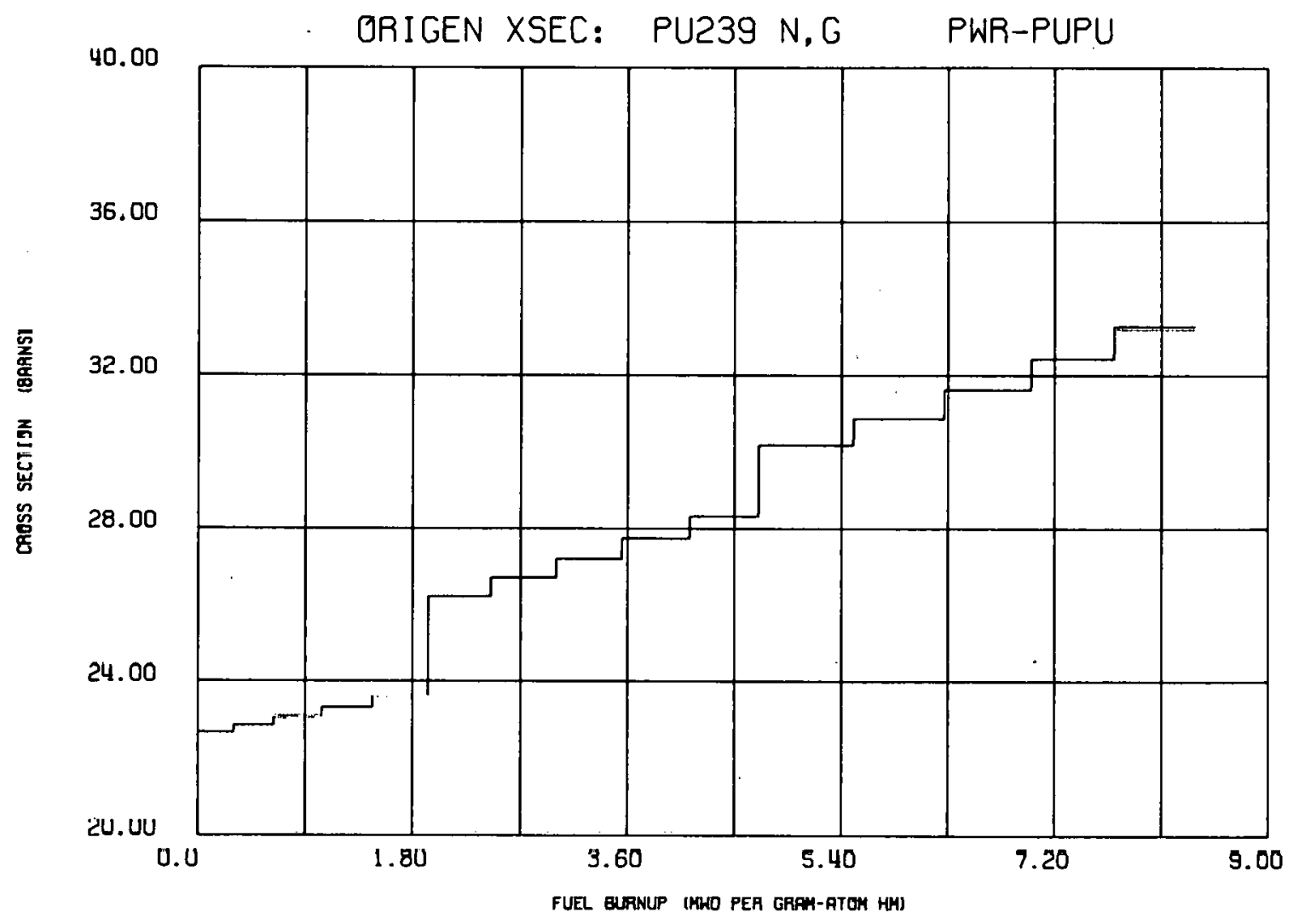

Fig. C.13. Burnup-dependent cross section of ${ }^{239} \mathrm{Pu}(n, \gamma)$ reaction for PWR-PuPu fuel. 


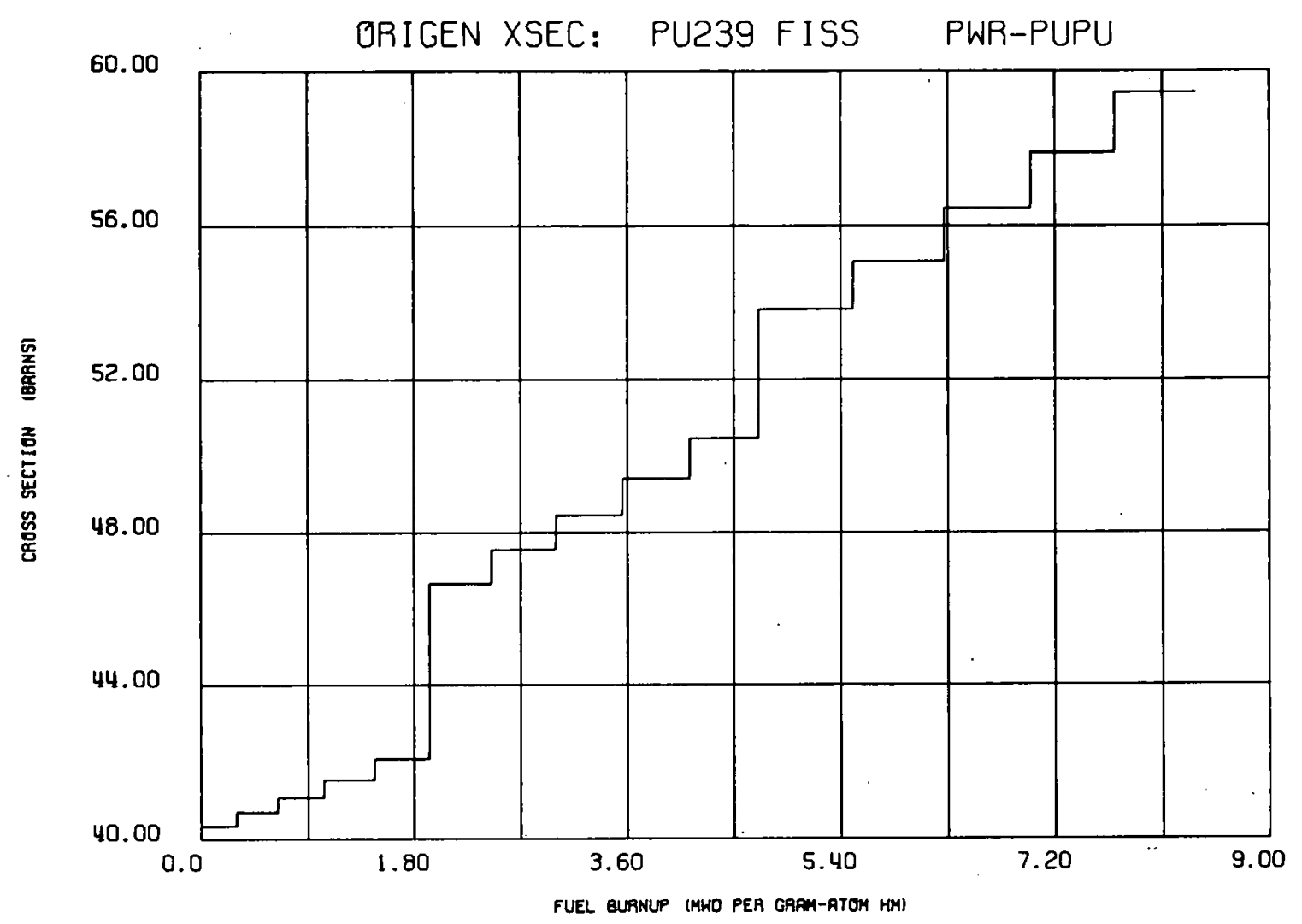

Fig. C.14. Burnup-dependent cross section of ${ }^{239} \mathrm{Pu}$ (n,fission) reaction for PWR-FuFu fuel. 


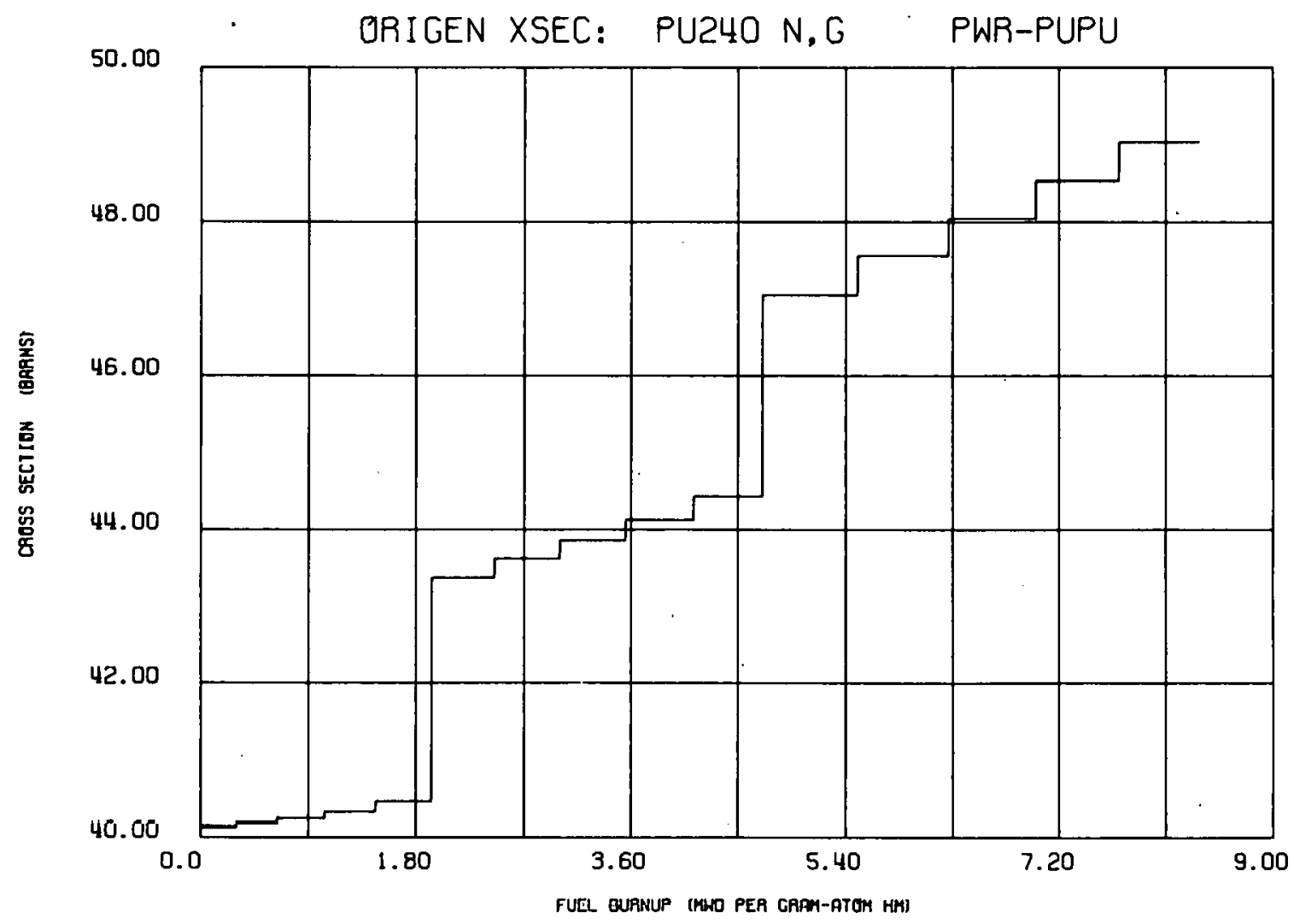

Fig. C.15. Burnup-dependent cross section of ${ }^{240} \mathrm{Pu}(n, \gamma)$ reaction for PWR-PuPu fuel. 


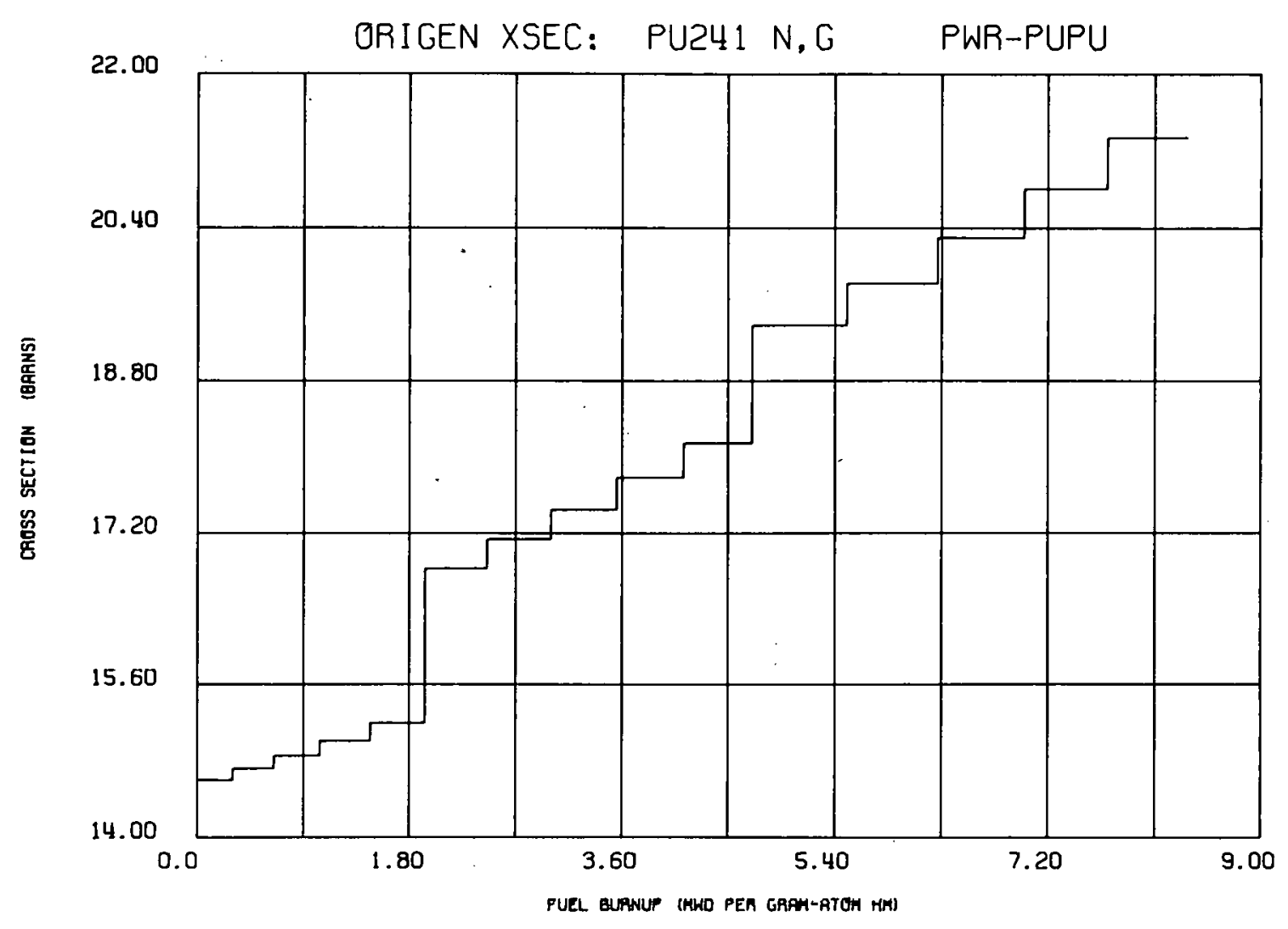

Fig. C.16. Burnup-dependent cross section of ${ }^{241} \mathrm{Pu}(n, \gamma)$ reaction for PWR-PuPu fuel. 


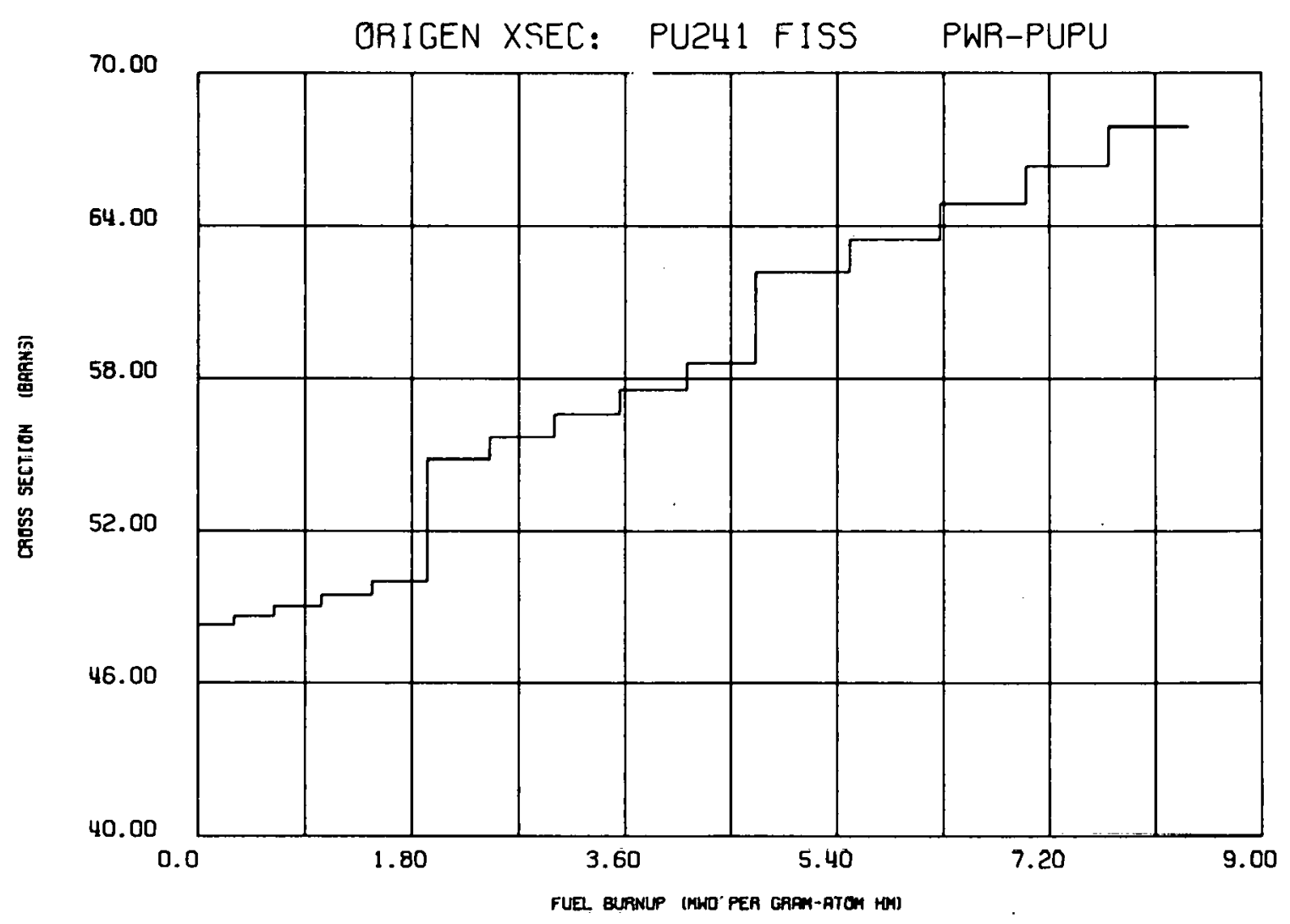

Fig. C.17. Burnup-dependent cross section of ${ }^{241} \mathrm{Pu}$ (n,fission) reaction for $\mathrm{PWR}-\mathrm{PuPu}$ fuel. 


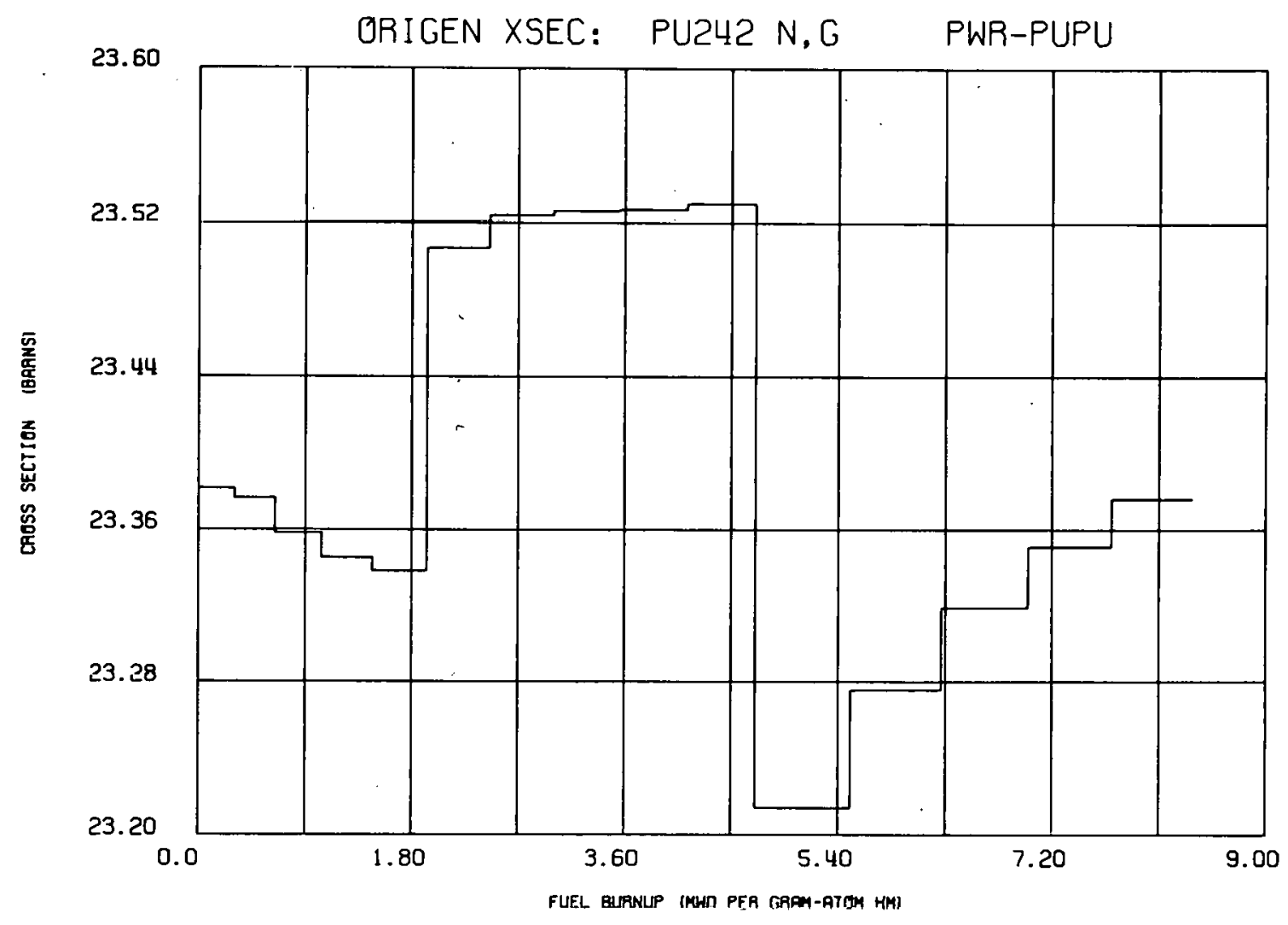

Fig. C.18. Burnup-dependent cross section of ${ }^{242} \mathrm{Pu}(n, \gamma)$ reaction for PWR-PuPu fuel. 
Table C.1. Cross sections as a function of burnup for a PWR-U

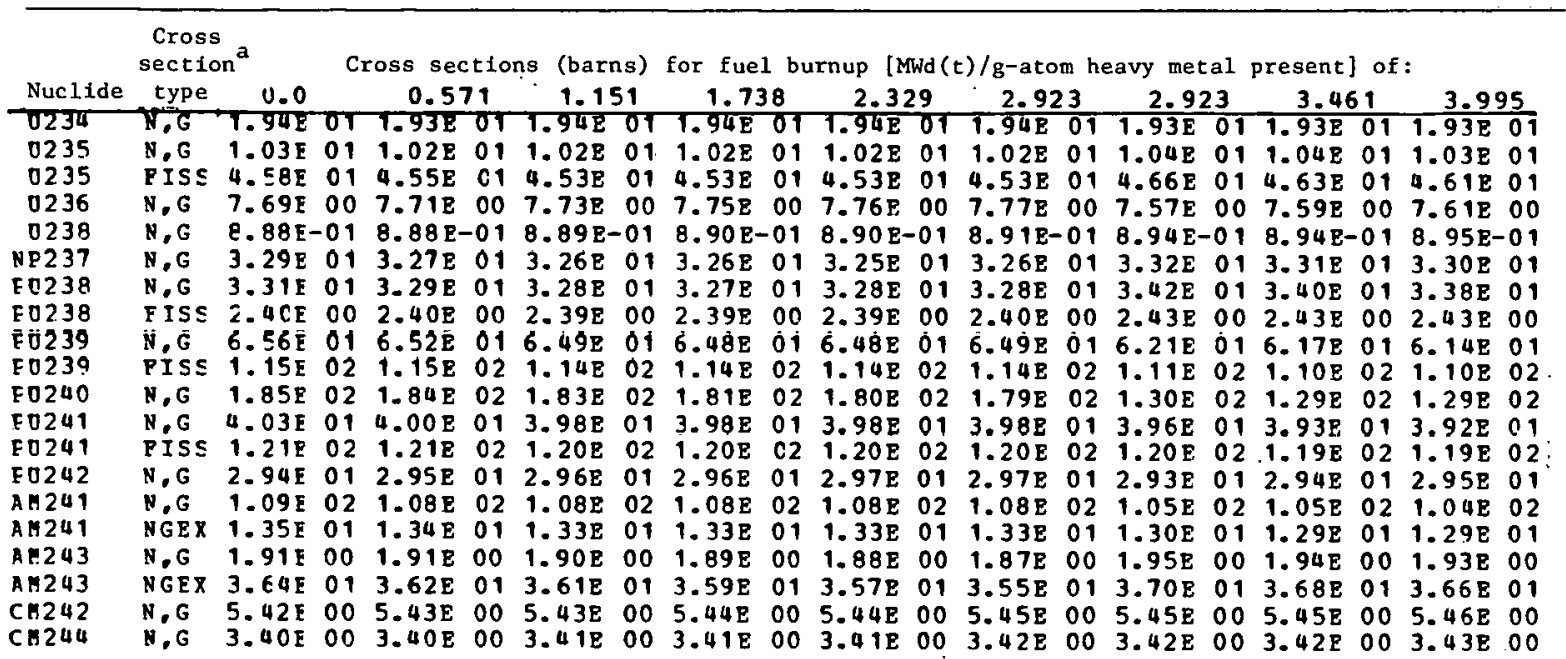

\begin{tabular}{|c|c|c|c|c|c|c|c|c|c|c|c|c|c|c|c|c|c|c|c|}
\hline & & & & & & & & & & & & & & & & & & & \\
\hline & & & & & & & & $\overline{9}$ & & 6. & & 55 & & 7 & 38 & & & 8.0 & \\
\hline $2=$ & & & & & & & & & & & & & & & & & & & \\
\hline & & & & & & & & & & & & & 01 & & $\begin{array}{l}01 \\
01\end{array}$ & & & & \\
\hline 23 & - & & ou & & ve & & Uu & & $u$ & & U & & U & & UU & & & & \\
\hline & & & .01 & & -01 & & 01 & & 1 & & & & $=01$ & & & & & & \\
\hline & & & 01 & & & & & & & & 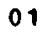 & & 01 & & & & & & \\
\hline & & & 01 & 3. & 0 & 3. & 01 & & 01 & & 01 & & 01 & & 01 & & & & \\
\hline & I & & 00 & & 0 & & 00 & & 00 & & 00 & & 00 & & & & & & 00 \\
\hline & .6 & & 01 & & 0 & & 01 & & 01 & & 01 & & 01 & & 01 & & 01 & & \\
\hline & & & 02 & & 0 & & לס & & & & 03 & & 03 & & & & & & \\
\hline & & & 02 & & 02 & 1.2 & 02 & & 02 & & 02 & & 02 & & & & & & \\
\hline & & & 01 & & 0 & 3. & 01 & & & 3. & 01 & E & 01 & & & & $c$ & & \\
\hline & & & 02 & & 0 & & & & & & 02 & & 02 & & & & & & \\
\hline & 1 & & 0 & & 0 & & & & 01 & & 01 & & 01 & & 01 & & & & \\
\hline & & & 02 & & & & & & & & 2 & & 02 & & & & & & \\
\hline & & & 01 & & 0 & & & & & & 01 & & 01 & & & & & & \\
\hline & & & 00 & & 0 & & & & & & 00 & & & & & & & & \\
\hline & & & 0 & & 0 & & & & & & $n$ & & & & & & & & \\
\hline & & & & & & & & & & & & & & & & & & & \\
\hline & & & & & & & & & & & & & & & & & & & \\
\hline
\end{tabular}

${ }_{\mathrm{N}, G}=$ (n,gamma) to a ground stace; $\mathrm{NGEX}=(\mathrm{n}$, gamma) to an excited state; FISS $=(n$, fission). 
lable C.2. Cross sections as a function of burnup for a PWK-YuU

\begin{tabular}{|c|c|c|c|c|c|c|c|c|c|c|c|c|c|c|c|c|c|}
\hline & $\begin{array}{r}\text { Cros } \\
\text { secti }\end{array}$ & & & & & & & & & & a & III & & metal $p$ & & & \\
\hline 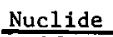 & type & 0 & & & & 6 & & 2.42 & 20 & 3.13 & & 3.82 & 21 & 3.821 & 4.29 & & 4.786 \\
\hline 17 & $\mathrm{~N}, \mathrm{G}$ & 203 & 01 & 01 & 01 & & 01 & 2.01 & 01 & 2.018 & 01 & 2.018 & 01 & 1.5 & 2. & 01 & 2 \\
\hline $\begin{array}{l}02 \\
02\end{array}$ & $\begin{array}{l}\text { NG G } \\
\text { FISS }\end{array}$ & & $\begin{array}{l}01 \\
01\end{array}$ & & $\begin{array}{l}01 \\
01\end{array}$ & & $\begin{array}{l}01 \\
01\end{array}$ & & 00 & & $\begin{array}{l}00 \\
01\end{array}$ & & $\begin{array}{l}00 \\
01\end{array}$ & $\begin{array}{lll}E & 0 & 0 \\
E & 0 & 1\end{array}$ & & $\begin{array}{l}00 \\
01\end{array}$ & $\begin{array}{lll}\mathbb{E} & 0 & 0 \\
\mathrm{E} & 0 & 1\end{array}$ \\
\hline & & & $\begin{array}{l}00 \\
.01\end{array}$ & & $\begin{array}{r}00 \\
-01\end{array}$ & & $\begin{array}{r}00 \\
-01\end{array}$ & & $\begin{array}{r}00 \\
-01\end{array}$ & & $\begin{array}{r}00 \\
-01\end{array}$ & & $\begin{array}{r}00 \\
-01\end{array}$ & & & & \\
\hline & $\mathrm{N}, \mathrm{C}$ & 3.3 & 01 & & 01 & & 01 & & 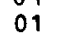 & & 01 & & 01 & 3 & & 01 & \\
\hline & & & 01 & & 01 & 3. & 01 & & 0 & & 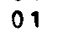 & & 01 & 1 & & 01 & 3 \\
\hline & & & 0 & & 00 & & 00 & & 0 & & 0 & & 00 & & & & \\
\hline & $\mathrm{N}$, & & 01 & & 01 & & 0 & & 0 & & 01 & & 09 & 1 & & 01 & \\
\hline & & & 02 & & 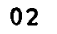 & & 02 & & 02 & & 02 & & 02 & 92 & & & \\
\hline & $\mathrm{N}, \mathrm{C}$ & & 02 & 1.5 & 02 & 1.5 & 02 & 1. & 02 & 1. & 02 & & 02 & $\begin{array}{ll}E & 02\end{array}$ & & 02 & \\
\hline & & & 01 & & & & 01 & & 0 & & 0 & & & & & & \\
\hline & & & 02 & & 02 & & 02 & & 02 & & 0 & & & $\begin{array}{ll}E & 02\end{array}$ & & & ( \\
\hline & & & 01 & & 01 & & 01 & & 01 & & 01 & & 0 & 1 & & & \\
\hline & & & & & 02 & & 0 & & & & & & & & & & \\
\hline & & & 01 & & $r_{0}$ & & 0 & & 0 & & 01 & & 01 & $E 01$ & & 0 & E 01 \\
\hline & & & 00 & & 00 & & 00 & & 00 & & 00 & & & & & & \\
\hline & & & 0 & & & & & & 0 & & 01 & & & & & & \\
\hline & & & & & 00 & & $O C$ & & 0 & & 00 & & 00 & $\mathbf{E}$ & & 00 & E 00 \\
\hline & & & & & 50 & & 0 & & 00 & $3.48 \mathrm{E}$ & 00 & & 00 & $3.49 \mathrm{E} 00$ & $3.50 \mathrm{E}$ & 00 & $3.50 \mathrm{E}$ \\
\hline
\end{tabular}

Cross sections (barns) for fuel burnup [MWd(t)/g-atom heavy metal present] of:

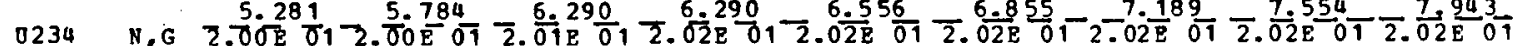

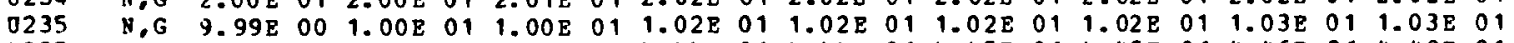
0235 PISS 4.32E $014.33 \mathrm{E} 014.34 \mathrm{E} 01$ 4.44E 01 4.44E 01 4.45E 01 4.45E 01 4.46E 01 4.48E 01

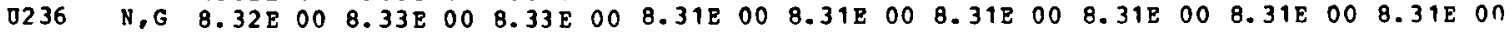
0238 N.G 9.40E-01 9.41E-01 9.41E-01 9.51E-01 9.51E-01 9.51E-01 9.51E-01 9.52E-019.52E-01 NP237 N,G 3.19E $013.20 \mathrm{E} 01$ 3.20E 01 3.23E 01 3.23E 01 3.23E 01 3.23E 01 3.23E 01 3.24E 01

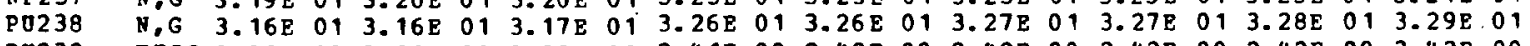

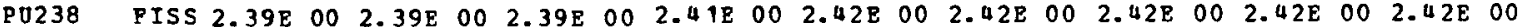

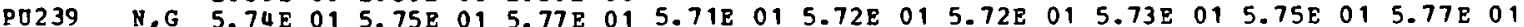

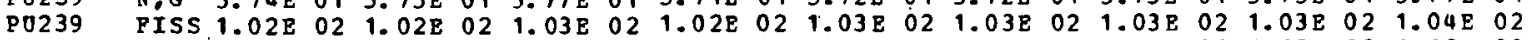

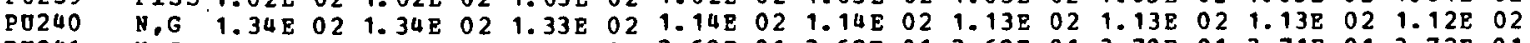

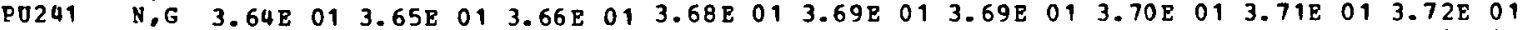
PO241 PISS 1.11E 02 1.11E 02 1.11E 02 1.12E 02 1.13E 02 1.13E 02 1.13E 02 1.13E 02 1.13E 02

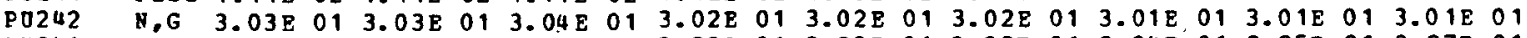

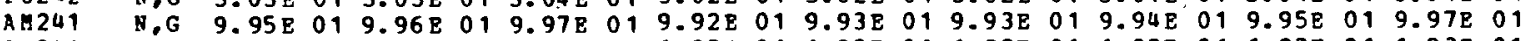

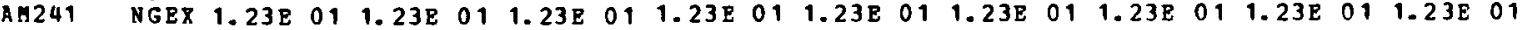

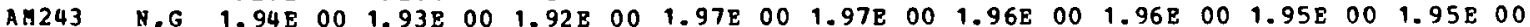

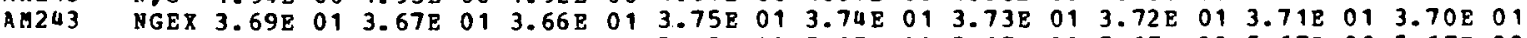

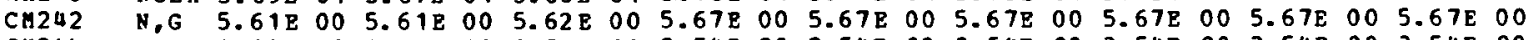
CH244 N,G 3.50E $00 \quad 3.51 \mathrm{E} 00 \quad 3.51 \mathrm{E} \quad 00 \quad 3.54 \mathrm{E} \quad 00.3 .54 \mathrm{E} 00 \quad 3.54 \mathrm{E} \quad 00 \quad 3.54 \mathrm{E} 00 \quad 3.54 \mathrm{E} \quad 00 \quad 3.54 \mathrm{E} \quad 00$

\footnotetext{
$a_{N, G}=(n, g a m m a)$ to a ground state; $N G E X=(n, g a m m a)$ to an excited state; FISS = ( $\left.n, f i s s i o n\right)$.
} 
Table c.3. Croce cectionc ac a function of burnup for a PWR-PuPu

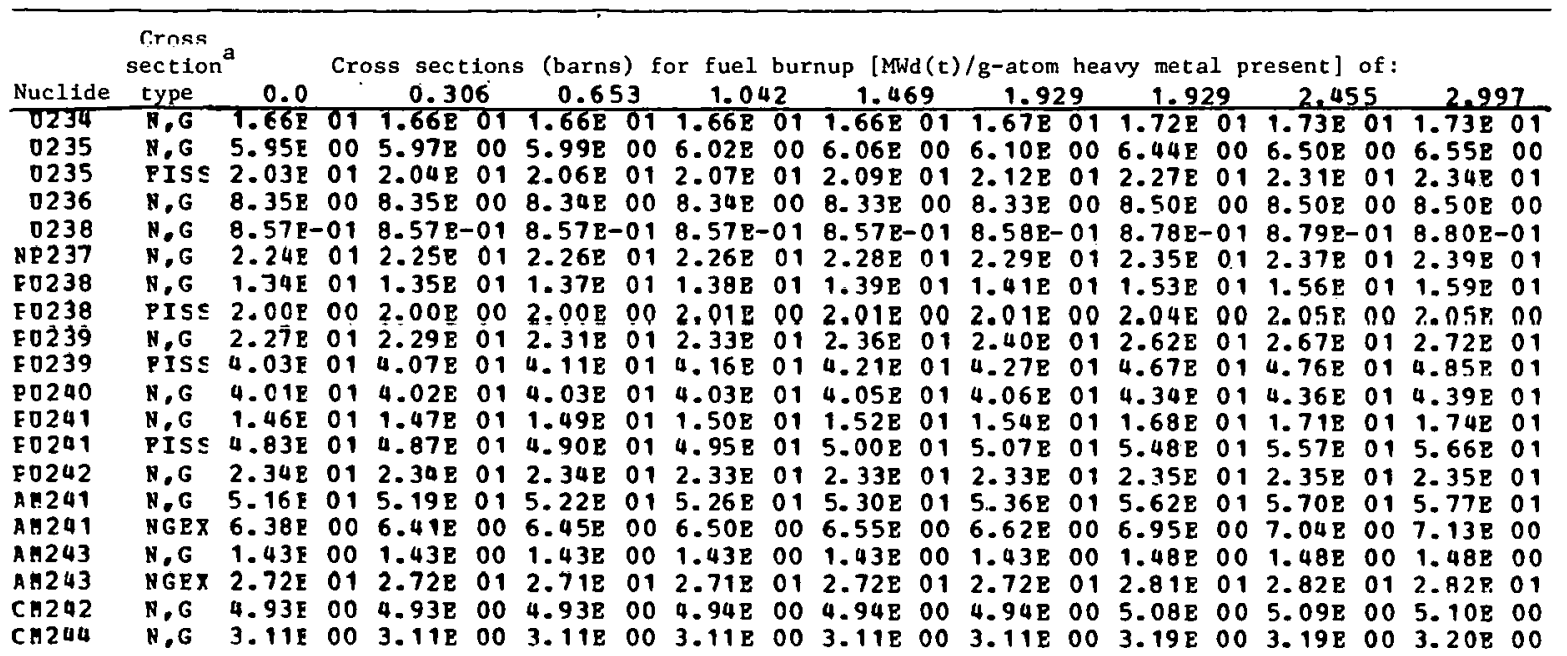

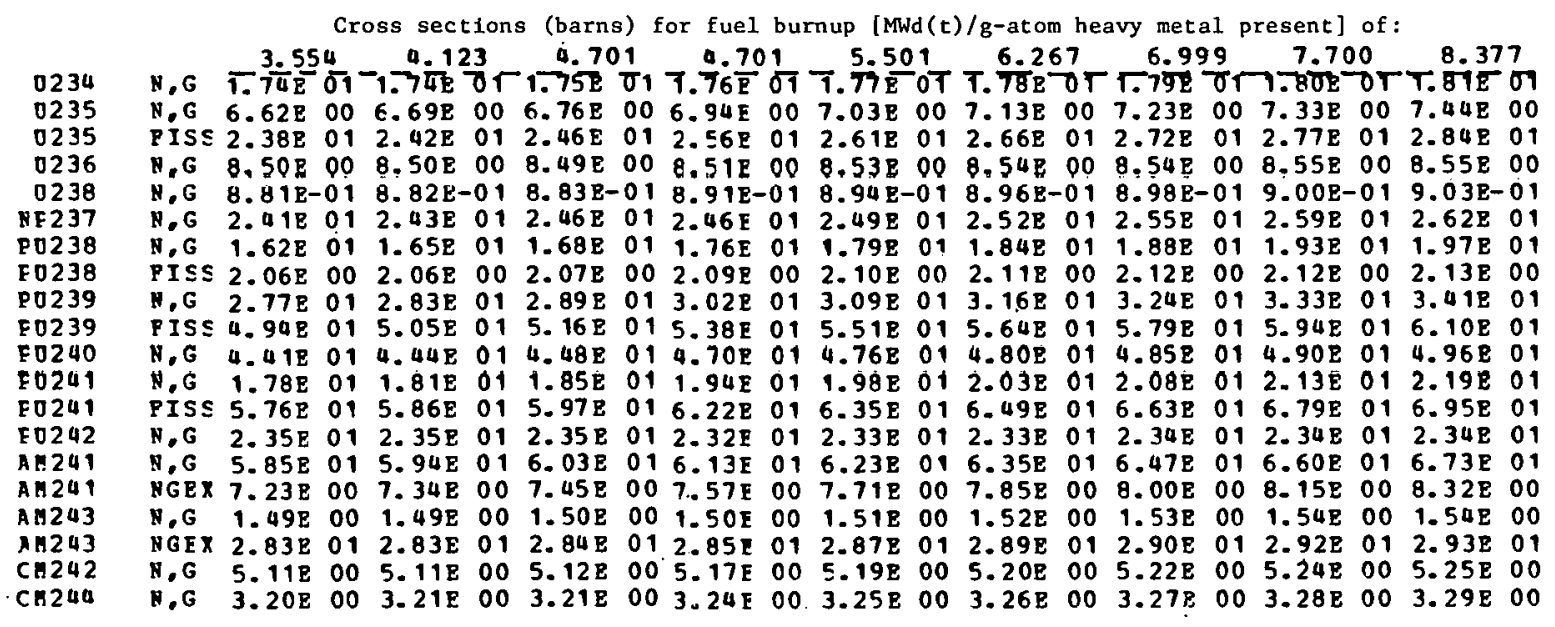

$\mathrm{a}_{\mathrm{N}, \mathrm{G}}=(n$, gamma $)$ to a ground state; $\mathrm{NGEX}=(n$, gamma $)$ to an excited state; FISS $=(n$, fission $)$. 
Table C.4. Cross sections as a function of burnup for a BWR-l

C:oss a

Cross seztions (barns) for fuel burnup [MWd(t)/g-atom heavy getal present] of:

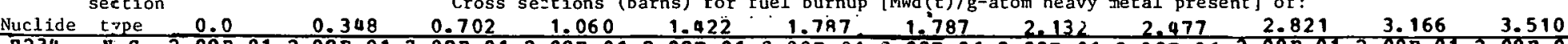

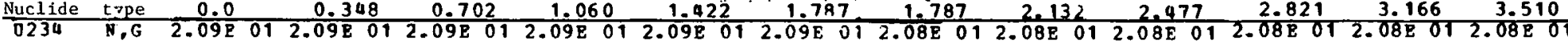

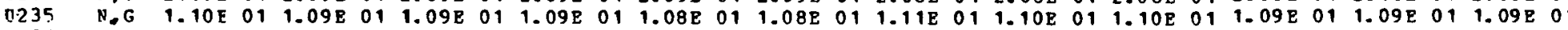

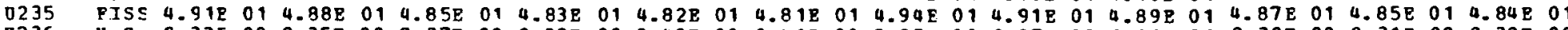

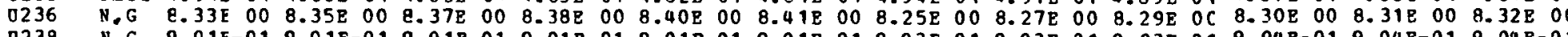

R23B N.G 9.01E-01 9.01E-01 9.01E-01 9.01E-01 9.01E-01 9.01E-01 9.03E-01 9.03E-019.03E-019.04E-019.04E-01 9.04E-01

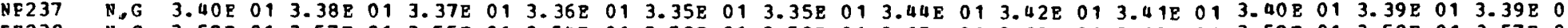

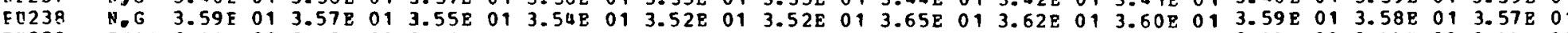

FO238 PISS 2.44E 00 2.43E 00 2.43E 00 2.43E 00 2.42E $00 \quad 2.42 \mathrm{E} \quad 00 \quad 2.45 \mathrm{E} \quad 00 \quad 2.45 \mathrm{E} \quad 00 \quad 2.45 \mathrm{E} \quad 00 \quad 2.44 \mathrm{E} \quad 00 \quad 2.44 \mathrm{E} \quad 00 \quad 2.44 \mathrm{E} \quad 00$

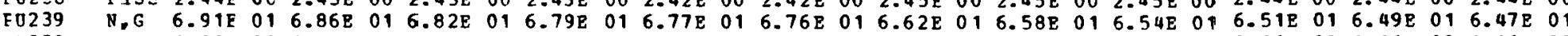

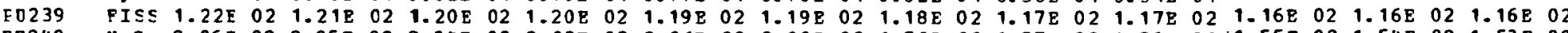

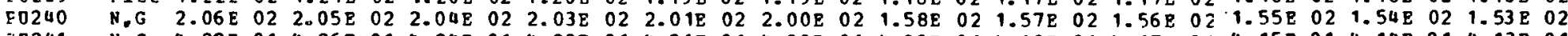

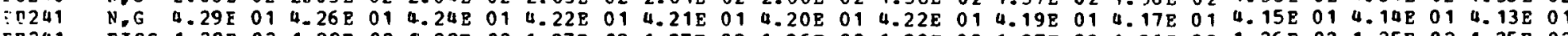

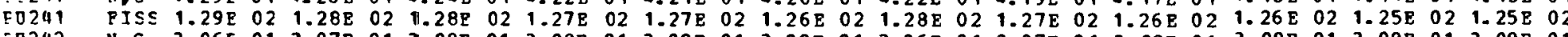

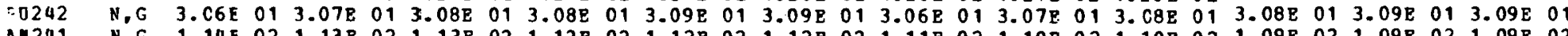

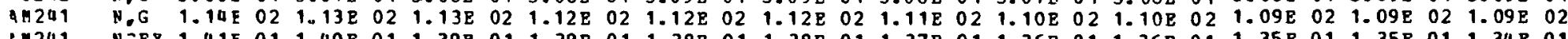

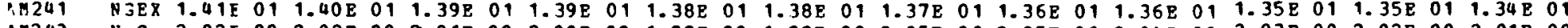

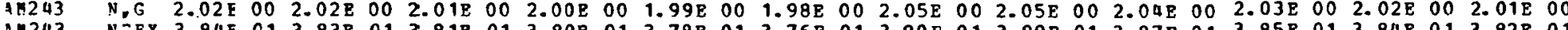

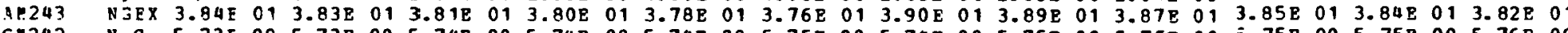

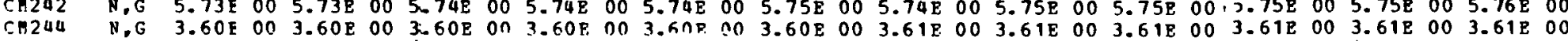

Cross sections (barns) for fuel burnup [MWd( $t) / g$-atom heavy netal present] of:
0234

1235

0235

0238

NE237

EO238

$\mathrm{F} 0238$

E0239

E0239

FO240

E0241

E0241

EO242

A 241

A 241

A. 243

A 243

Cr 244

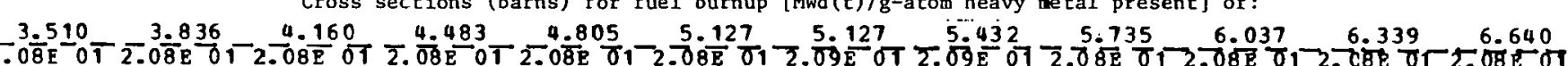

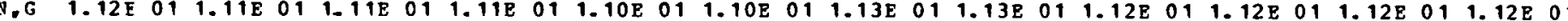

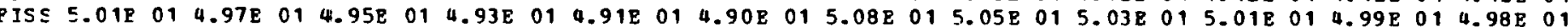

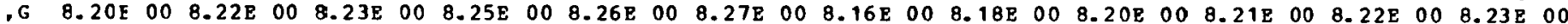
,G 9.C8F-01 9.08E-01 9.08E-01 9.08E-01 9.08E-01 9.08E-01 9.13E-01 9.13E-019.13E-01 9.13E-019.14E-01 9.14E-01

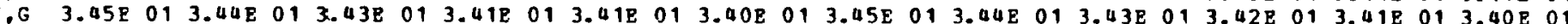

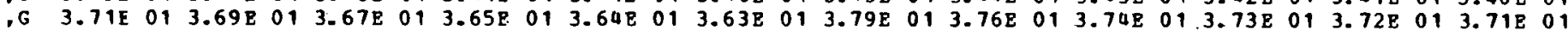
$\begin{array}{llllllllllllllllllllllllllll} & & & \end{array}$

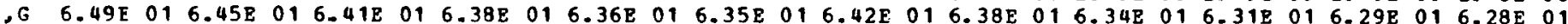

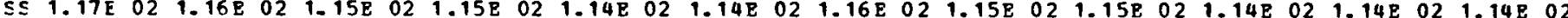

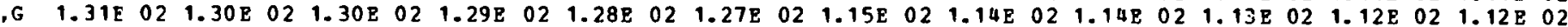

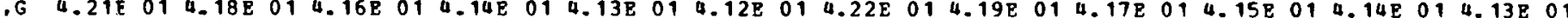

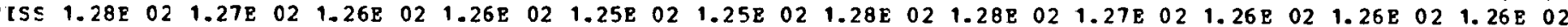
$\begin{array}{llllllllllllllllllllllllllllll} & \end{array}$ $\begin{array}{lllllllllllllllllllllllll}.6 & 1.10 \mathrm{E} & 02 & 1.09 \mathrm{E} & 02 & 1.08 \mathrm{E} & 02 & 1.08 \mathrm{E} & 02 & 1.08 \mathrm{E} & 02 & 1.07 \mathrm{E} & 02 & 1.08 \mathrm{E} & 02 & 1.08 \mathrm{E} & 02 & 1.07 \mathrm{E} & 02 & 1.07 \mathrm{E} & 02 & 1.07 \mathrm{E} & 02 & 1.06 \mathrm{E} & 02\end{array}$ $\begin{array}{lllllllllllllllllllllllll} & & \end{array}$

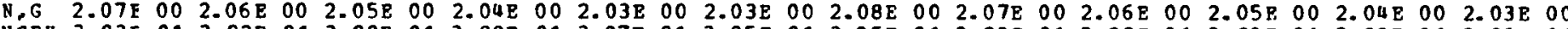
$\begin{array}{llllllllllllllllllllllll} & & \end{array}$

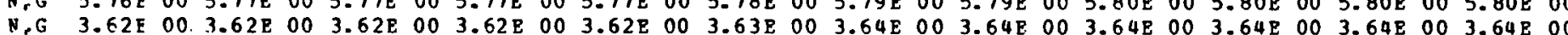

$a_{N, G}=(n, g a m m a)$ to a ground state; NGEX $=(n$, gamma $)$ to an excited state; FISS $=(n$, fission $)$ 
Cross

Crcss sections (barns) for fuel burnup [Midd ( $t) / g$-atom heavy metal present] of:

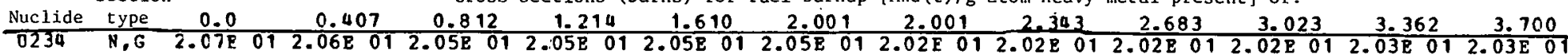

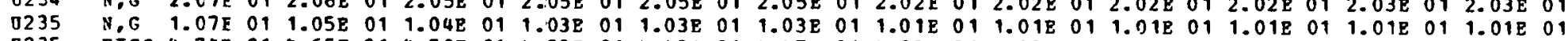

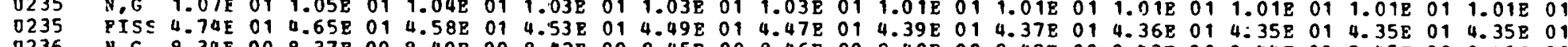

2236 N.G 8.34E 00 8.37E 00 8.00E

NE23.J N.G 9.0OE-O 8.98E-01 8.97E-01 8.97E-01 8.97E-01 8.98E-01 8.98E-01 8.98E-01 8.99E-018.99E-01 8.99E-01 9.00E-0

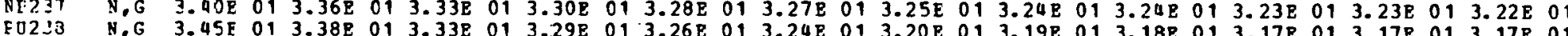

ED23B NISS 2.UE OT

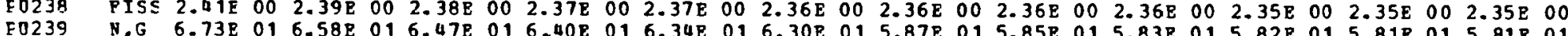

F0239 N.G 6.TE 01 .

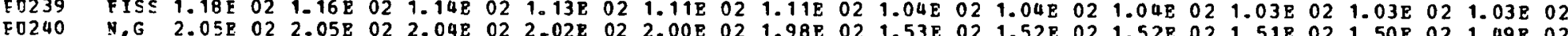

FO241 NG

FO24 NOL

FO242 1 (

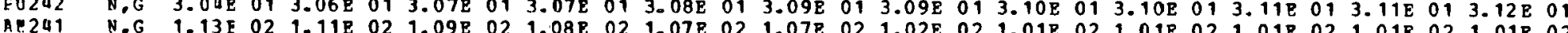

AR241

AH243 $\quad$ GE

AM2U3 NG 2 NGE 3 .

CM242 NG 5.

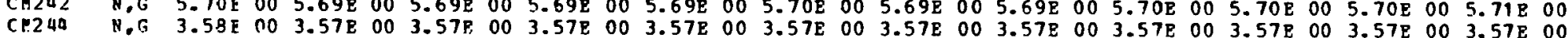

Cross secrions (barns) for fuel burnup [MWd( $t) / g-a$ tom heavy metal present] of

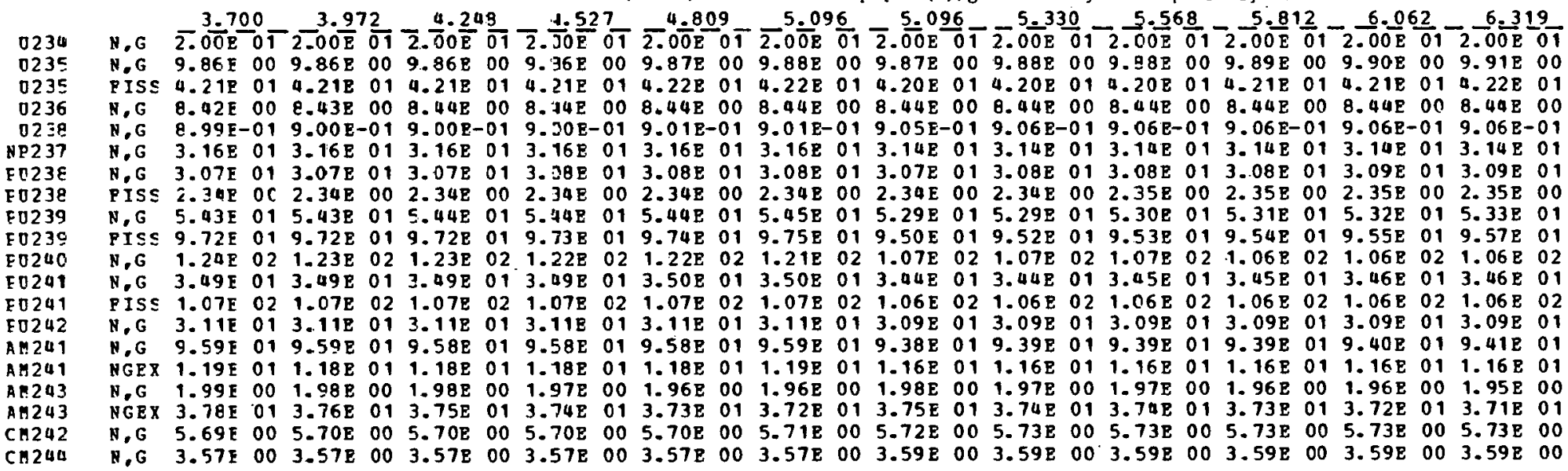

$a_{N, G}=(n$, gamma $)$ to a grcund state; NGEX $=$ in, gamra) to an excited state; FISS $=(n$, fission $)$. 
Cross

Cross sections (barns) for fuel burnup [MWd( $t) / g$-atom heavy metal preser.t] of:

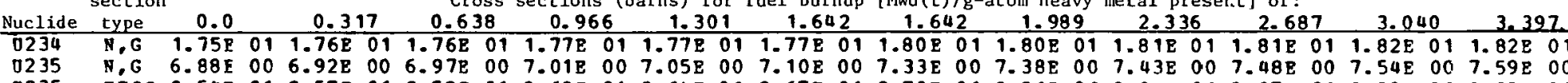

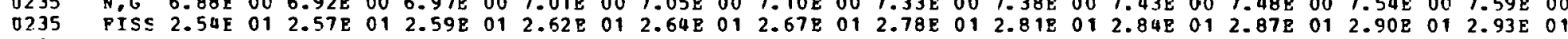

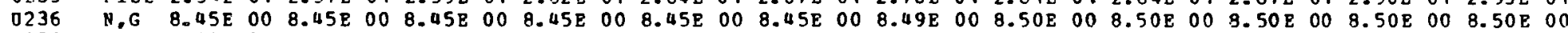

$0238 \quad \mathrm{~N}, \mathrm{G} \quad 8.30 \mathrm{E}-018.31 \mathrm{E}-018.31 \mathrm{E}-01$ 8.32E-01 8.33E-01 8.34E-01 8.44E-018.45E-01 8.46E-018.47E-018.48E-018.49E-01

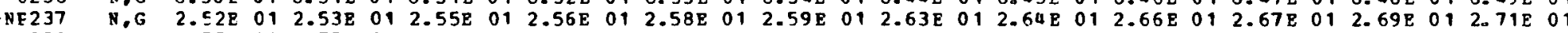

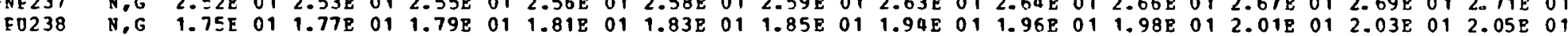

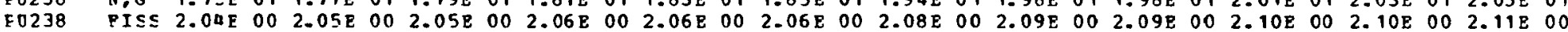

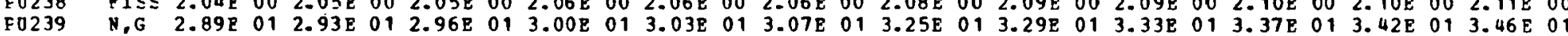

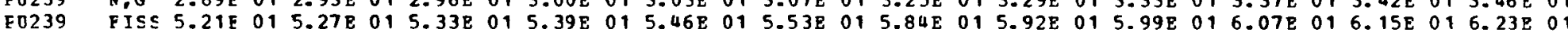

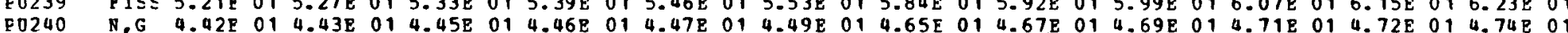

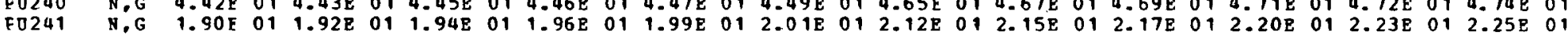

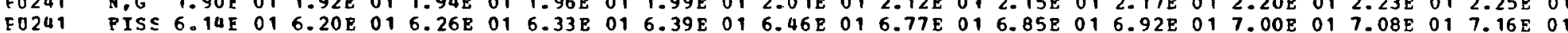

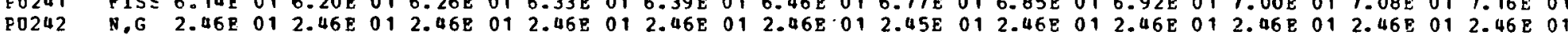

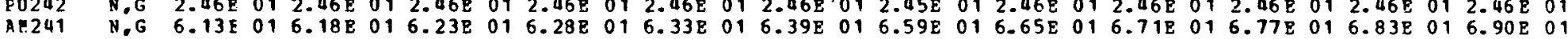

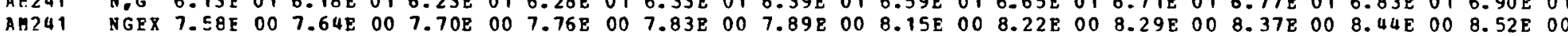

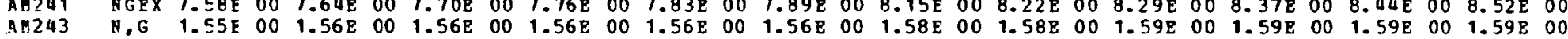

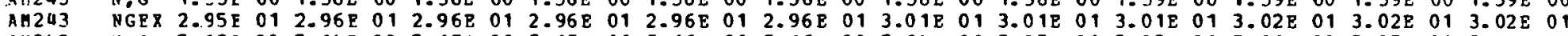

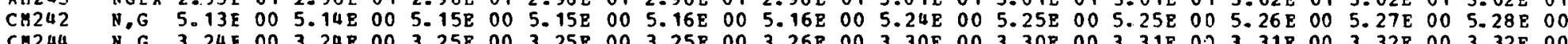

Cross sections (barns) for fue: burnup [MWd(t)/g-atom heavy metal present] of:

0234

0235

0235

0238

NP237

FO238

P0238

E0239

FO2 41

024

FO242

A. 24

A 241

A. 243

A 243

C. 242

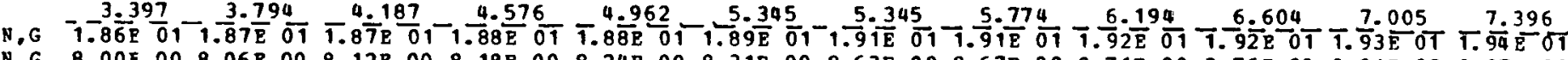

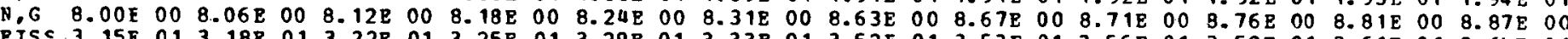
$\begin{array}{lllllllllllllllllllllll} & \end{array}$

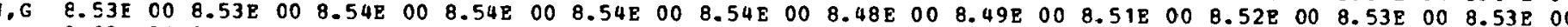
N.G 8.60E-01 8.5 1E-01 8.63E-01 8.64 E-01 8.66E-01 8.67E-01 8.73E-01 8.74E-01 8.76E-01 9.77E-01 8.79E-01 8.80E-01 2.80E 01 2.82E $012.84 \mathrm{E} 01$ 2.85E 01 2.87E 01 2.89E $012.94 \mathrm{E} 012.96 \mathrm{E} 012.97 \mathrm{E} 012.98 \mathrm{E} 013.00 \mathrm{E} 013.02 \mathrm{E} 01$

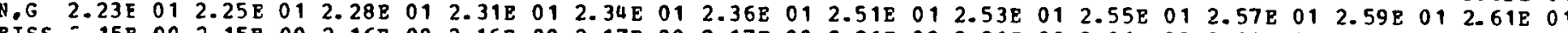

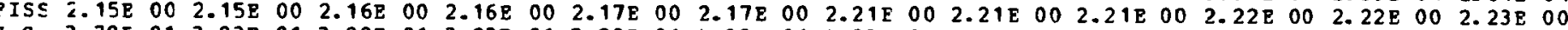

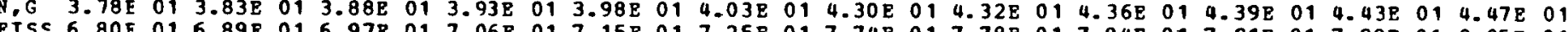

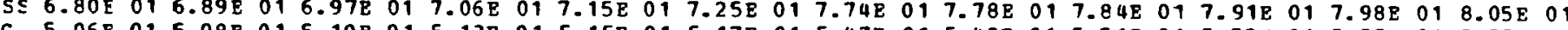

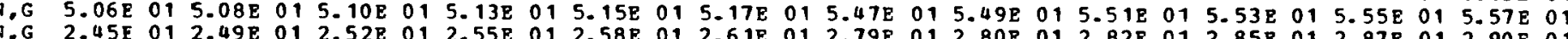

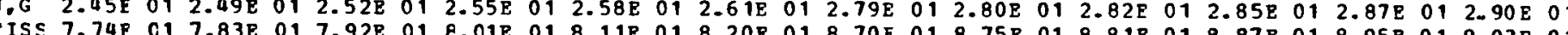

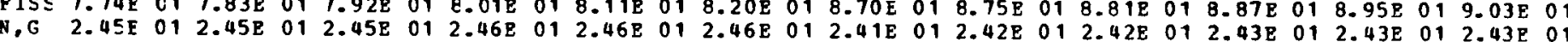
N.G T.J1E $017.38 \mathrm{E} 017.45 \mathrm{E} 017.53 \mathrm{E} 017.60 \mathrm{E} 017.67 \mathrm{E} 017.99 \mathrm{E} 018.03 \mathrm{E} 018.08 \mathrm{E} 018.13 \mathrm{E} 018 \mathrm{~B}$

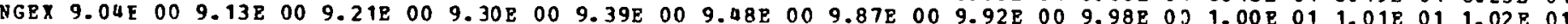

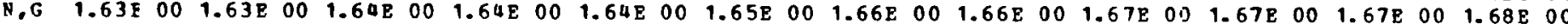

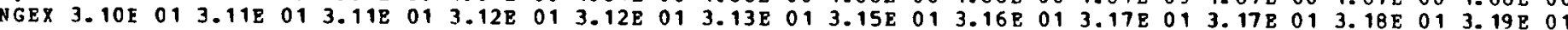

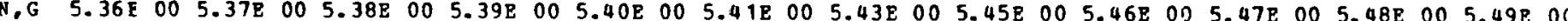

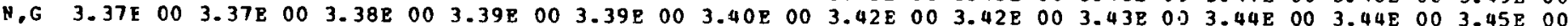

$a_{N, G}=(n$, gamma $)$ to a grour:d state; NGEX $=(n$, gamma $)$ to an excited state; FISS $=(n, f$ ission $)$ 
THIS PAGE

\section{WAS INTENTIONALLY LEFT BLANK}


ORNL/TM-6051

INTERNAL DISTRIBUTION

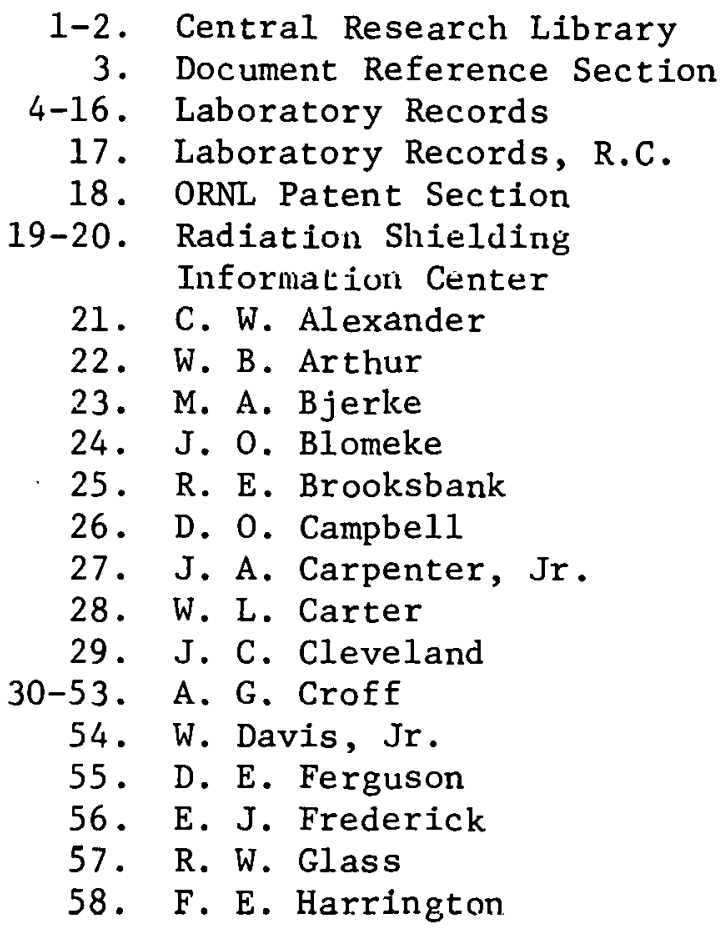

59. O. W. Hermann

60. J. R. Hightower

61. P. R. Kasten

62. C. W. Kee

63. F. C. Maienschein

64. J. R. Marshall

65. W. C. McClain

66. G. W. Morrison

67. E. Newman

68. J. P. Nichols

69. K. J. Notz

70. L. M. Petrie

71. C. D. Scott

72. H. F. Soard

73. J. W. Wachter

74. R. G. Wymer

75. G. R. Choppin (consultant)

76. E. L. Gaden, Jr. (consultant)

77. L. J. Colby, Jr. (consultant)

78. L. E. Swabb, Jr. (consultant)

79. K. D. Timmerhaus (consultant)

EXTERNAL DISTRIBUTION

80-106. Technical Information Center, Oak Ridge, TN 37830

DOE-ORO, Oak Ridge, TN 37830

107. Research and Technical Support D1vision

108. D. E. Large

DOE, Washington, DC 20545

109. G. K. Oerte1

110. R. D. Walton

Battelle Northwest, P. O. Box 999, Richland, WA 99352

111. A. M. Platt

112. E. J. Merrill

Argonne National Laboratory, 9700 South Cass Ave., Argonne, IL 62439

113. Y. I. Chang

114. M. Steindler 
Sandia Laboratories, P. O. Box 5800, Albuquerque, NM 87115

115. D. E. Bennett

E. I. du Pont de Nemours and Company, Savannah River Laboratory, Aiken, SC 29801

116. R. W. Benjamin

Los Alamos Technical Associates, P. O. Box 410, Los Alamos, NM 87544 117. S. E. Logan

General Electric, Mail Code S-34, P. O. Box 5020, Sunnyvale, CA 94086 118. S. L. Beaman

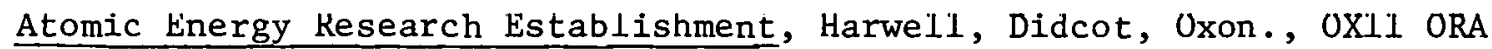
England

119. J. R. Grover

National Radiation Protection Board, Harwel1, Didcot, Oxon., OXl1 ORA, England

120. G. N. Kelley

Centre d'études nuclếaiers de Fontenay-aux-Roses, B.P. No. 6, Fontenayaux-Roses, France

121. Y. Sousselier

OECD-Nuclear Energy Agency, 38, Boulevard Suchet, F-75016 Paris, France 122. M. Takahashi

International Atomic Energy Agency, P. 0. Box 590, A-1011 Vienna, Austria 123. K. J. Schneider

Lab. Teoria e Calcolo Reottori, C.N.E.N.-C.S.N. Casaccia, CP 2400, I-00100 Rome, Italy

124. L. Tondinelli

Institut für Heisse Chemie Kernforschungszentrum, Postfach 3640,75

Karlsruhe, Germany

125. H. O. Hang

Commission of the European Communities, CCR Euratom, I-21200 Ispra,

Italy

126. F. Girardi

Chalmers University of Technology, Dept. of Nuclear Chemistry, S-402 20 Göteborg, Sweden

127. J. O. Liljenzin

CCR Euratom, I-21200, Ispra, Italy

128. W. Hage 
Studsvik, AB Atomenergi, Fack, S-611 01, Nyköping 1, Sweden 129. E. Hellstrand

Cadarach, B.P. No. 1, 13115 Sant-Paul-lez-Durance, France 130. J. Bouchard

AERE, Harwe11, Oxfordshire OXII ORA, England 131. A. McKay

Battelle Pacific Northwest Laboratories, Battelle Boulevard, Richland, WA 99352

132. H. Burkholder 